\title{
Criticality Analysis for Proposed Maximum Fuel Loading in a Standardized SNF Canister with Type 1a Baskets
}

Soon Sam Kim

Chad Pope

Larry L. Taylor

February 2007

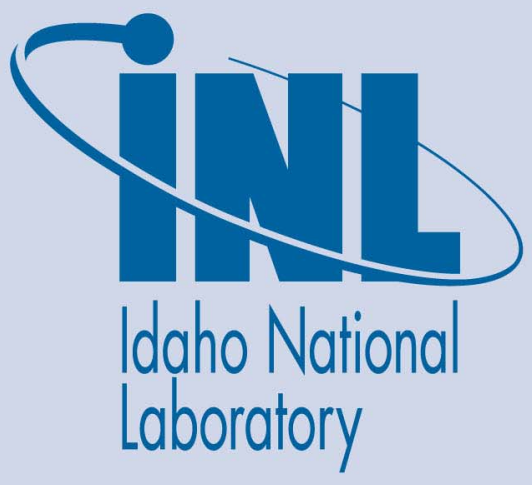

The INL is a U.S. Department of Energy National Laboratory operated by Battelle Energy Alliance 
INL/EXT-07-12326

\title{
Criticality Analysis for Proposed Maximum Fuel Loading in a Standardized SNF Canister with Type 1a Baskets
}

\author{
Soon Sam Kim ${ }^{1}$ \\ Chad Pope ${ }^{2}$ \\ Larry L. Taylor ${ }^{2}$ \\ ${ }^{1}$ Lawrence Livermore National Laboratory \\ ${ }^{2}$ Idaho National Laboratory
}

February 2007

Idaho National Laboratory
Idaho Falls, Idaho 83415

Prepared for the

U.S. Department of Energy

Assistant Secretary for Environmental Management

Under DOE Idaho Operations Office

Contract DE-AC07-05ID14517 
NATIONAL SPENT NUCLEAR FUEL PROGRAM ENGINEERING DESIGN FILE

EDF-NSNF-068

Revision 0

Page 1 of 84

Title: Criticality Analysis for Proposed Maximum Fuel Loading in a Standardized SNF Canister with Type 1a Baskets

\begin{tabular}{|c|c|c|c|}
\hline \multicolumn{4}{|c|}{$\begin{array}{l}\text { 1. Activity Title: National Spent Nuclear Fuel Program } \\
\text { 2. WBS No. C.B. } 30.03 \cdot 02 \cdot 02 \cdot B 2\end{array}$} \\
\hline \multicolumn{4}{|c|}{\begin{tabular}{l|c|c|c} 
3. Approval & Typed Name & Signature & Date \\
\end{tabular}} \\
\hline Preparer & Soon Sam Kim & & \\
\hline Preparer & Chad Pope & & \\
\hline Preparer & Larry L. Taylor & & \\
\hline PSO QE & Neal S. MacKay & & \\
\hline $\begin{array}{l}\text { 4. Distribution: } \\
\text { (Name and Mail Stop) }\end{array}$ & $\begin{array}{l}\text { T. J. Hill } \\
\text { Brett Carlsen } \\
\text { H. H. Loo } \\
\text { Lee Montierth }-2 \text { copies } \\
\text { Soon Sam Kim }-2 \text { copies } \\
\text { Chad Pope }-2 \text { copies } \\
\text { L. L. Taylor }-6 \text { copies } \\
\text { P. D. Wheatley } \\
\text { NSNFP files }-12 \text { copies }\end{array}$ & & \\
\hline
\end{tabular}

\section{Purpose:}

This document represents a summary version of the criticality analysis done to support loading SNF in a Type 1a basket/standard canister combination. Specifically, this engineering design file (EDF) captures the information pertinent to the intact condition of four fuel types with different fissile loads and their calculated reactivities. These fuels are then degraded into various configurations inside a canister without the presence of significant moderation. The important aspect of this study is the portrayal of the fuel degradation and its effect on the reactivity of a single canister given the supposition there will be continued moderation exclusion from the canister. Subsequent analyses also investigate the most reactive 'dry' canister in a nine canister array inside a hypothetical transport cask, both dry and partial to complete flooding inside the transport cask. The analyses also includes a comparison of the most reactive configuration to other benchmarked fuels using a software package called TSUNAMI, which is part of the SCALE 5.0 suite of software. 
Revision 0

Page 2 of 84

Title: Criticality Analysis for Proposed Maximum Fuel Loading in a Standardized SNF Canister with Type 1a Baskets

\section{CONTENTS}

ACRONYMS

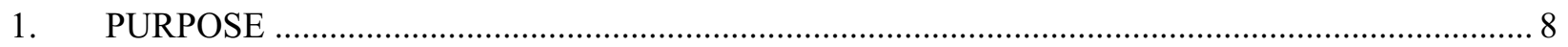

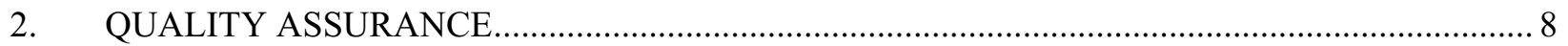

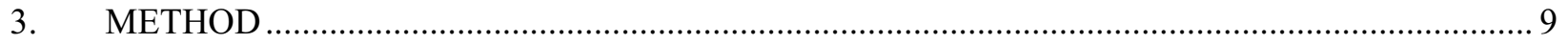

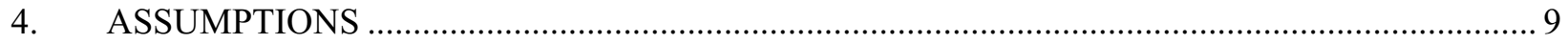

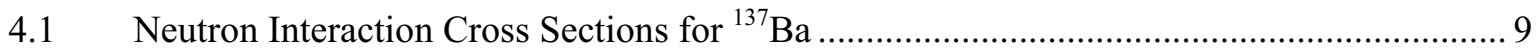

4.2 Neutron Interaction Cross Sections for Zinc .............................................................. 9

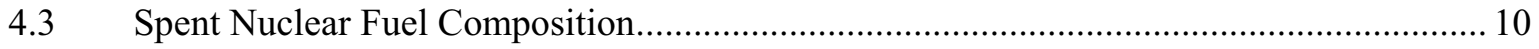

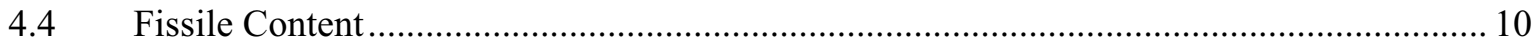

4.5 Moderator Saturation of Fissile Matrix Material............................................................. 10

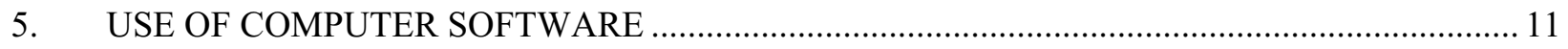

$5.1 \quad$ Software

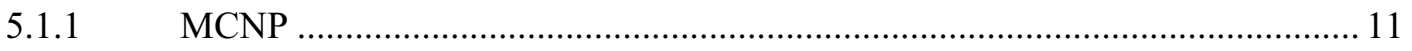

5.1.2 SCALE 5.0

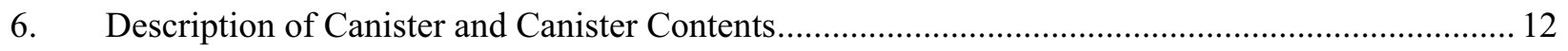

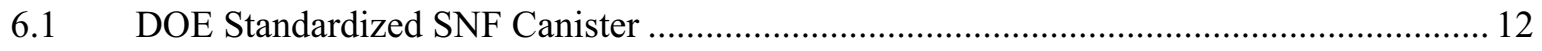

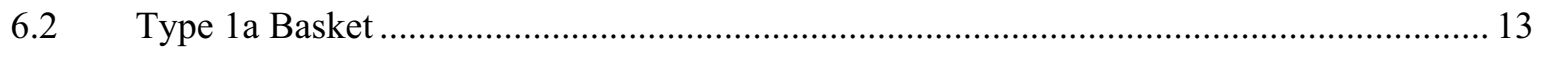

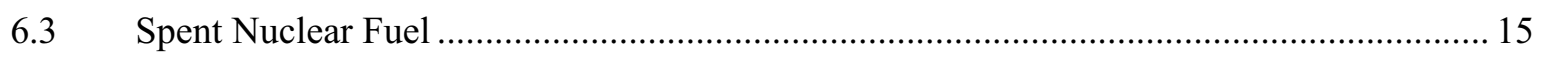

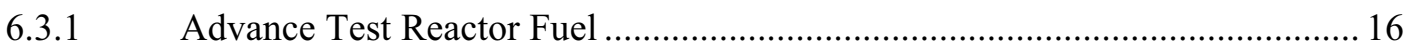

6.3.2 Missouri University Research Reactor Fuel............................................... 20

6.3.3 Massachusetts Institute of Technology Fuel .................................................. 22

6.3.4 Oak Ridge Research Reactor Fuel ............................................................ 24

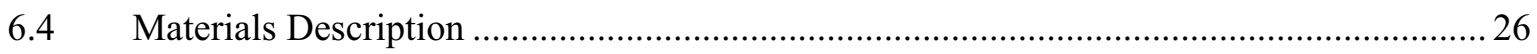


Title: Criticality Analysis for Proposed Maximum Fuel Loading in a Standardized SNF Canister with Type 1a Baskets

7. Calculations

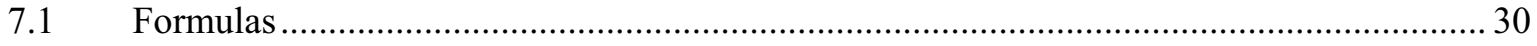

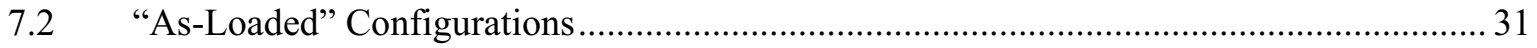

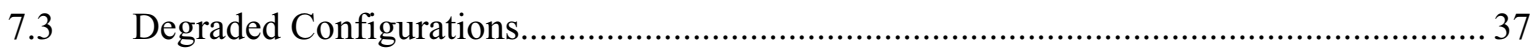

7.3.1 Fuel Debris Separated and Horizontally Reconfigured in Basket Compartments ... 37

7.3.2 Fuel Debris Separated and Vertically Reconfigured in Basket Compartments ........ 40

7.3.3 Basket Grid Plates Fail and Reconfigure Horizontally ......................................... 45

7.3.4 Basket Base Plates Fail and Fuel Debris Reconfigures Vertically ............................ 46

7.3.5 Fuel non-mechanistically separates and assembles in a sphere below basket and cladding material ............................................................................................... 48

7.3.6 Fuel non-mechanistically separates and assembles in a cylinder below basket and

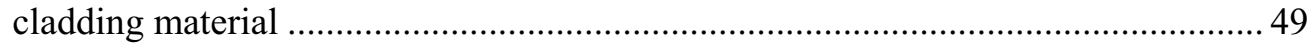

7.3.7 Fuel Debris in a Flooded Canister ..................................................................... 51

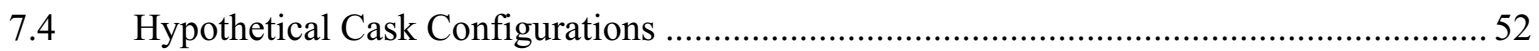

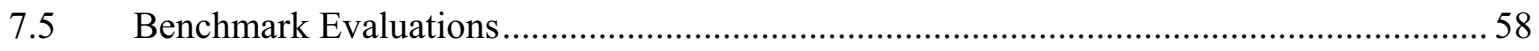

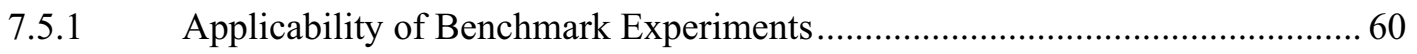

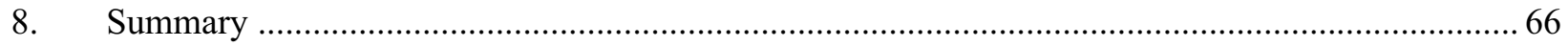

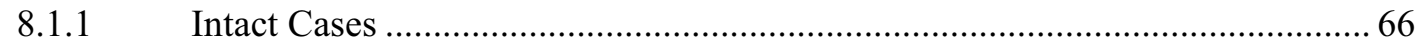

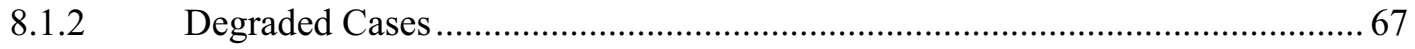

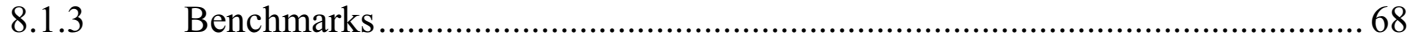

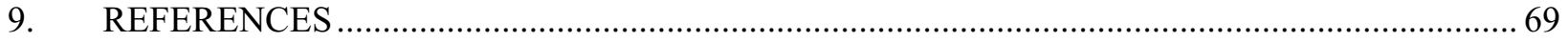

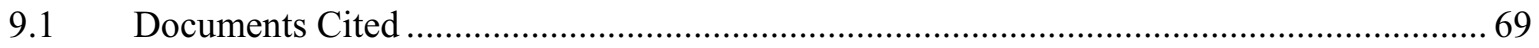

9.2 Codes, Standards, Regulations, and Procedures .......................................................... 71

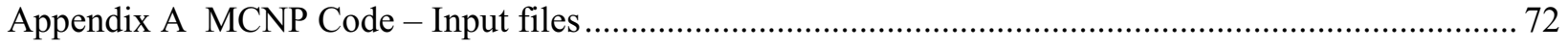

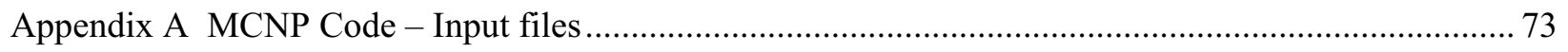

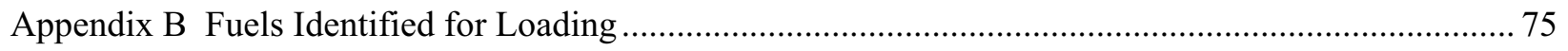

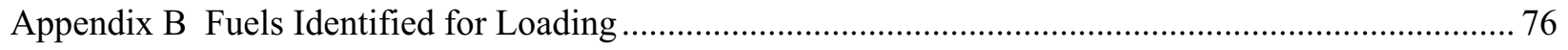


Title: Criticality Analysis for Proposed Maximum Fuel Loading in a Standardized SNF Canister with Type 1a Baskets

B-1 References

\section{FIGURES}

Figure 6.1. Plan view of a typical DOE standardized SNF canister. .................................................. 13

Figure 6.2-1. Cross-sectional schematic of the Type 1a basket structure and sleeve................................ 14

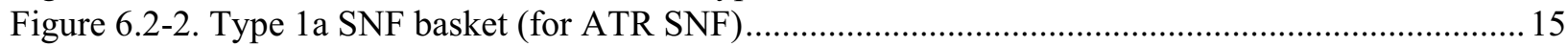

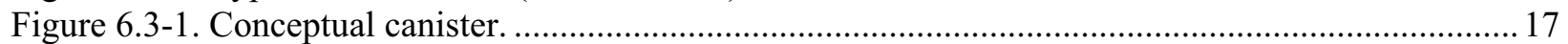

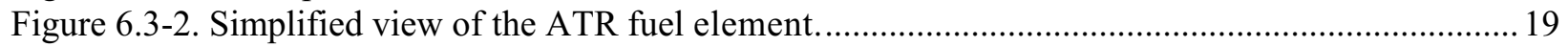

Figure 6.3-3. Simplified view of the MURR fuel element (cropped length)........................................21

Figure 6.3-4. Simplified view of the MIT fuel element (cropped length). ..............................................23

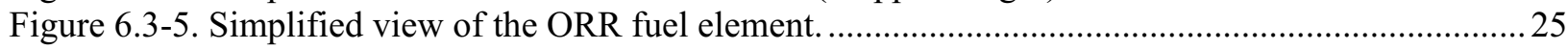

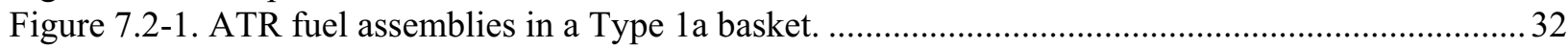

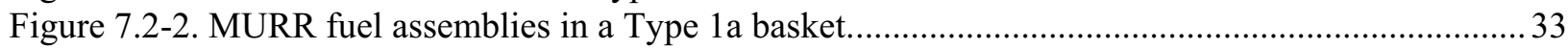

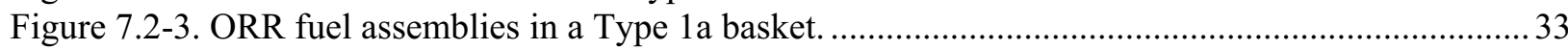

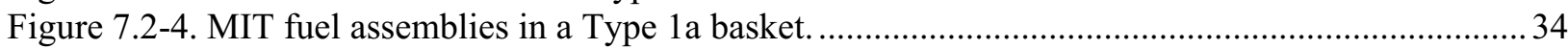

Figure 7.2-5. Gd effect on system reactivity for intact internals in a single, water reflected canister with

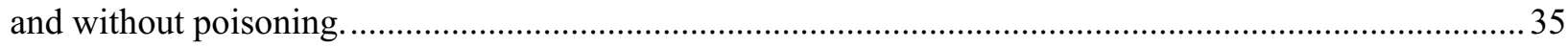

Figure 7.2-6. Calculated reactivities for intact SNF loaded in a fully-flooded canister...........................36

Figure 7.3.1-1 Cross section of canister with fuel debris separated and horizontally reconfigured in a Type

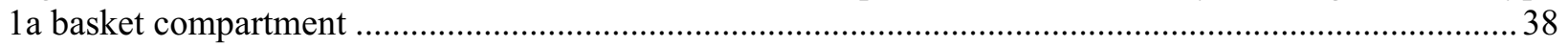

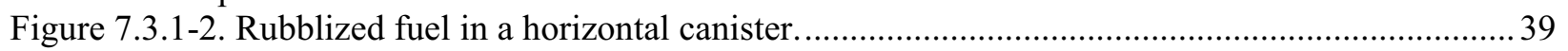

Figure 7.3.2-1. Reactivities of degraded fuel in vertically oriented 18 " canister.................................... 41

Figure 7.3.2-2 Side view cross-section of two stacked, vertically oriented Type 1a basket compartments.

Figure $7.3 .2-3$. Reactivity as a function of void fraction in ATR fuel

Figure 7.3.2-4. Reactivity as a function of void fraction in MURR fuel. ................................................. 44

Figure 7.3.3-1a Conventional ATR spacing within Type 1a basket .......................................................45

Figure 7.3.3-1b Collapsed basket plates constrained by fuel shape .........................................................45

Figure 7.3.4-1 Collapsed basket plates and fuel debris constrained in basket compartments ..................47

Figure 7.3.4-2. Reactivity in a vertically oriented canister with fuel degraded and reconfigured in one set

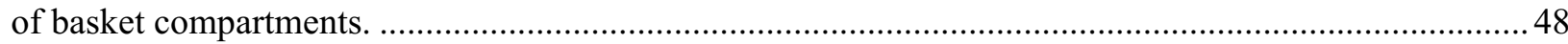

Figure 7.3.5-1. Spherical fuel debris without poison in sphere. .......................................................... 49

Figure 7.3.6-1. Cylindrical fuel debris without poison in cylinder..................................................50

Figure 7.3.6-2. Degraded fuel accumulated in the bottom of a vertically oriented cask. ....................... 51

Figure 7.4-1. Flooded transport cask with degraded fuel in most reactive (cylindrical- vertical) SNF nine-

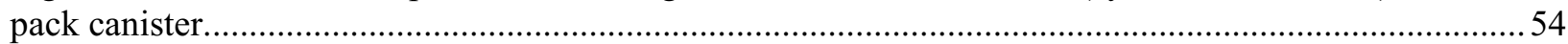

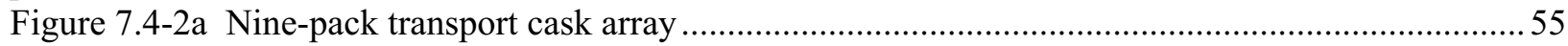

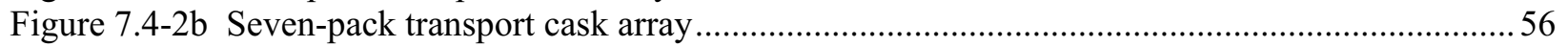

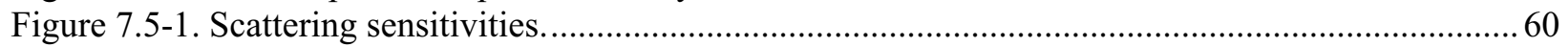

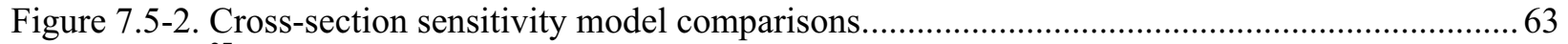

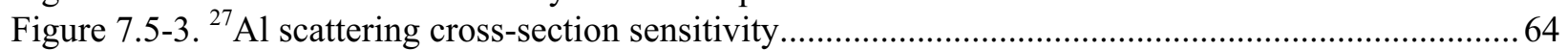

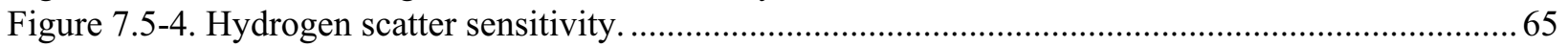



1a Baskets

\section{TABLES}

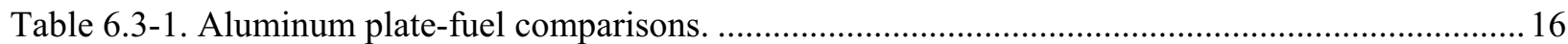

Table 6.3-2. Dimensions and fissile loading for individual plates in ATR fuel element.......................... 19

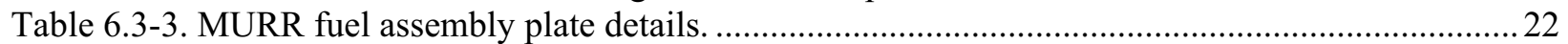

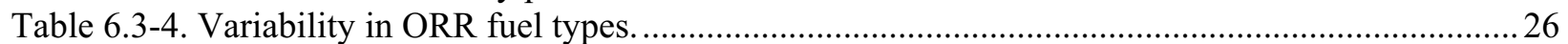

Table 6.4-1. Composition and density of stainless steel 304L (basket material)...........................27

Table 6.4-2. Composition and density of stainless steel 316L. (canister material) ..........................27

Table 6.4-3. Composition and density of carbon steel A516 Grade 70 (canister impact plates) ................28

Table 6.4-4. Composition and density of Ni-Gd alloy. (poison material in basket grid)..........................22

Table 6.4-5. Composition and density of Aluminum 6061. (cladding material) .....................................28

Table 6.4-6. ATR fuel number densities used in this report. ................................................................29

Table 7.2-1. Water-reflected, loaded SNF canister with dry/intact internals......................................... 32

Table 7.2-2. Results of intact fuels in a fully-flooded canister. ............................................................. 36

Table 7.3.1-1. Effect of fuel rubblization in a horizontally oriented basket compartments...................... 39

Table 7.3.2-1. Reactivities for degraded fuel in a vertically oriented canister. ....................................... 40

Table 7.3.2-2. Results for degraded ATR (20) fuel inside vertically oriented basket compartments.........43

Table 7.3.2-3. Results for degraded MURR (24) fuel inside vertically oriented canister compartments... 44

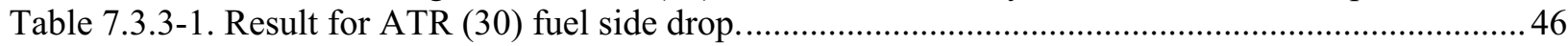

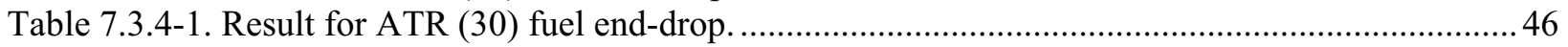

Table 7.3.5-1. Results of degraded spherical fuel matrix mass in SNF canister.......................................49

Table 7.3.6-1. Results of degraded cylindrical fuel matrix mass in SNF canister. ..................................50

Table 7.3.7-1. Results of degraded and flooded ATR fuel matrix mass in SNF canister.........................52

Table 7.4-1. Results of nine aluminum fueled canisters loaded in a cask..............................................53

Table 7.4-2 Reactivities of loaded fuel canisters $\mathrm{w} /$ intact internals inside a transport cask ....................56

Table 7.5-1. Comparison of MCNP and KENO models........................................................................5

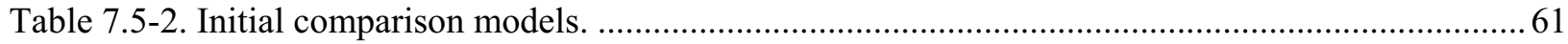

Table 7.5-3. $\mathrm{c}_{\mathrm{k}}$ values and $\mathrm{k}_{\mathrm{eff}}$ 's for application and benchmark experiments. ....................................... 61 
NATIONAL SPENT NUCLEAR FUEL PROGRAM ENGINEERING DESIGN FILE

EDF-NSNF-068

Revision 0

Page 6 of 84

Title: Criticality Analysis for Proposed Maximum Fuel Loading in a Standardized SNF Canister with Type 1a Baskets

\section{ACRONYMS}

AENCF average energy (of) neutrons causing fission

ASME American Society of Mechanical Engineers

ASTM American Society for Testing and Materials

ATR Advanced Test Reactor

BFS big physical stand

BOL beginning of life

BSC Bechtel SAIC, LLC

CRWMS Civilian Radioactive Waste Management System

DOE U.S. Department of Energy

DOE/RW DOE Office of Radioactive Waste

DWG drawing (document type)

EDF engineering design file

ENDF evaluated nuclear data file

FHU fuel-handling unit

HEU highly enriched uranium

HP Hewlett-Packard

$\mathrm{H} / \mathrm{X} \quad$ hydrogen to fissile ratio

ICSBE International Handbook of Evaluated Criticality Safety Benchmark Experiments

INEEL Idaho National Engineering and Environmental Laboratory

INL Idaho National Laboratory

IPPE Institute of Physics and Power Engineering (Russia)

$\mathrm{k}_{\mathrm{eff}} \quad$ Effective neutron multiplication factor

$\mathrm{M} \& \mathrm{O} \quad$ management and operations 
NATIONAL SPENT NUCLEAR FUEL PROGRAM ENGINEERING DESIGN FILE

EDF-NSNF-068

Revision 0

Page 7 of 84

Title: Criticality Analysis for Proposed Maximum Fuel Loading in a Standardized SNF Canister with Type 1a Baskets

MCNP Monte Carlo N-Particle Transport Code

MEU medium-enriched uranium

MIT Massachusetts Institute of Technology

MURR Missouri University Research Reactor

NSNFP National Spent Nuclear Fuel Program

OCRWM Office of Civilian Radioactive Waste Management

ORR Oak Ridge Research Reactor

PC personal computer

SCM software configuration management

SNF Spent Nuclear Fuel

$\mathrm{UAl}_{\mathrm{x}} \quad$ uranium aluminide

UNS Unified Numbering System

YMP Yucca Mountain Project 


\section{PURPOSE}

The objective of these analyses are to demonstrate that DOE SNF canisters loaded for disposal in the national repository with Type 1a baskets can also meet criticality safety under transportation scenarios prescribed by 10CFR71.55. Several DOE SNFs (Appendix B) show which SNFs will be packaged using a Type 1a basket configuration. Of these SNFs, the following four fuel types were considered among the most reactive, either because of their individual fissile loads (per assembly) or what their collective fissile content contributes to a loaded canister:

- $\quad$ Advanced Test Reactor (ATR)

- $\quad$ Oak Ridge Research Reactor (ORR)

- $\quad$ Missouri University Research Reactor (MURR)

- $\quad$ Massachusetts Institute of Technology (MIT).

These four fuel types are evaluated to identify the parameters they represent in terms of criticality safety for a loaded SNF canister, e.g. total fissile, enrichment, and linear fissile loading in a canister. The analyses demonstrate the technical viability of the DOE Standardized SNF canister and associated packaging for addressing transportation issues relative to criticality safety.

The preliminary analyses provide a baseline comparison between the individual fuel types for their proposed loading in single DOE SNF canisters. Analyses address reconfigured fuel (i.e. fuel debris) in both horizontal and vertical orientations of the canister and the debris contained within each basket compartment. Special cases also analyze bounding configurations in which the fuel debris from stacked baskets is consolidated within one set of basket compartments, meaning basket base plates do not keep the fuel debris from consolidating in one lumped mass. Special cases also examine a non-mechanistic case in which fissile material is consolidated in the bottom of the canister and away from any poisoned basket plates. The remaining analyses examine the transport cask cavity relative to an array of canisters with their content in their most reactive configuration and subject to various degrees of flooding.

\section{QUALITY ASSURANCE}

This document was developed and is controlled in accordance with NSNFP procedures. Unless noted otherwise, information must be evaluated for adequacy relative to its specific use if relied on to support design or decisions important to safety or waste isolation.

The NSNFP procedures applied to this activity implement DOE/RW-0333P, Quality Assurance Requirements and Description [DOE 2004a], and are part of the NSNFP Quality Assurance Program. The NSNFP Quality Assurance Program has been assessed and accepted by representatives of the Office of Quality Assurance within the Office of Civilian Radioactive Waste Management for the work scope of the NSNFP. The NSNFP work scope extends to the work represented in this report. 
EDF-NSNF-068

Revision 0

Page 9 of 84

Title: Criticality Analysis for Proposed Maximum Fuel Loading in a Standardized SNF Canister with Type 1a Baskets

The current, principal NSNFP procedures applied to this activity include the following:

- NSNFP 3.03, "Engineering Analysis"

- $\quad$ NSNFP Procedure 3.04, "Engineering Documentation"

- NSNFP Procedure 6.01, "Review and Approval of NSNFP Internal Documents"

- $\quad$ NSNFP Procedure 6.03, "Managing Document Control and Distribution".

\subsection{METHOD}

The method to perform the criticality calculations consists of using the Monte Carlo N-Particle Transport Code (MCNP) Version 4B2 [CRWMS 1998a, 1998b] to calculate the effective neutron multiplication factor of the waste package. The calculations are performed using the continuous-energy, cross-section libraries, which are part of the qualified code system MCNP 4B2 [CRWMS 1998a, 1998b].

\section{ASSUMPTIONS}

\subsection{Neutron Interaction Cross Sections for ${ }^{137} \mathrm{Ba}$}

Assumption: ${ }^{138} \mathrm{Ba}$ cross sections are assumed to adequately represent ${ }^{137} \mathrm{Ba}$ cross sections in the MCNP input..

Rationale: The cross sections of ${ }^{137} \mathrm{Ba}$ are not available in either evaluated nuclear data file ENDF/B-V or ENDF/B-VI cross-section libraries

Confirmation Status: This assumption is conservative, because the thermal neutron capture cross section and the resonance integral of ${ }^{137} \mathrm{Ba}$ (5.1 and 4 barn, respectively) are greater than the thermal neutron capture cross section and the resonance integral of ${ }^{138} \mathrm{Ba}(0.43$ and $0.3 \mathrm{barn}$, respectively) [Parrington et al. 1996, p. 34] and thus does not require further confirmation.

Use in the Calculation: This assumption is used in the analyses used to produce the results given in Section 7.

\subsection{Neutron Interaction Cross Sections for Zinc} input.

Assumption: Al cross sections are assumed to adequately represent zinc cross sections in the MCNP

Rationale: The cross sections of zinc are not available in the MCNP 4B2LV cross-section libraries.

Confirmation Status: This assumption is conservative because the thermal neutron capture cross section and the resonance integral of zinc [Parrington et al., 1996, p. 24] are greater than the thermal neutron 
EDF-NSNF-068

Revision 0

Page 10 of 84

Title: Criticality Analysis for Proposed Maximum Fuel Loading in a Standardized SNF Canister with Type 1a Baskets

capture cross section and the resonance integral of $\mathrm{Al}$ [Parrington et al., 1996, p. 21] and thus does not require further confirmation.

Use in the Calculation: This assumption is used in the analyses used to produce the results given in Section 7.

\subsection{Spent Nuclear Fuel Composition}

Assumption: Beginning-of-life composition is conservatively assumed in the calculations, and no credit is taken for the initial boron neutron absorber present in the fuel.

Rationale: This assumption is conservative, because it results in a higher $\mathrm{k}_{\mathrm{eff}}$ for the system.

Confirmation Status: This assumption does not require further confirmation.

Use in the Calculation: This assumption is used in the analyses used to produce the results given in Section 7.

\subsection{Fissile Content}

Assumption: Because the fuels analyzed are manufactured with various BOL fissile loadings, the highest fissile content is conservatively assumed.

Rationale: This assumption is conservative, because it maximizes the fissile isotope $\left({ }^{235} \mathrm{U}\right)$ content while minimizing the effect of neutron absorption by ${ }^{238} \mathrm{U}$.

Confirmation Status: This assumption does not require further confirmation.

Use in the Calculation: This assumption is used in the analyses used to produce the results given in Section 7.

\subsection{Moderator Saturation of Fissile Matrix Material}

Assumption: Voids within the fuel matrix are assumed to have the following values and conservatively assumed to be completely waterlogged.

- ATR $11 \% \quad$ (resultant $\mathrm{H} / \mathrm{X}$ ratio of $\sim 2.1 ; 89.18 \mathrm{~g} \mathrm{H}_{2} 0 /$ assembly)

- MURR $11 \% \quad$ (resultant $\mathrm{H} / \mathrm{X}$ ratio of $\sim 2.0 ; 58.94 \mathrm{~g} \mathrm{H}_{2} 0 /$ assembly)

- MIT $19.75 \% \quad$ (resultant $\mathrm{H} / \mathrm{X}$ ratio of $\sim 3.4 ; 70.04 \mathrm{~g} \mathrm{H}_{2} 0 /$ assembly)

- ORR $\quad \sim 30 \% \quad$ (resultant $\mathrm{H} / \mathrm{X}$ ratio of $\sim 8.8 ; 116.83 \mathrm{~g} \mathrm{H}_{2} 0$ /assembly)

Rationale: Fuel matrix materials have a production density that is less than theoretical density for the given composition [Knight, pg. 21, Fig. 17] and/or may have undergone fracturing due to radiation 
Page 11 of 84

Title: Criticality Analysis for Proposed Maximum Fuel Loading in a Standardized SNF Canister with Type 1a Baskets

exposure. Water may have become entrained in the fuel matrix interstices during time of immersion in reactor operations and/or wet pool storage because of cladding defects. It is not likely that any fuel drying process will be able to remove this trapped water if present.

Confirmation Status: This assumption is conservative because the assumed water promotes thermal neutron behavior, and because not all of the fuel matrix interstices are water saturated due to drying and the fact that they may not be interconnected. This assumption does not require further confirmation.

Use in the Calculation: This assumption is used in the analyses used to produce the results given in Section 7.

\section{USE OF COMPUTER SOFTWARE}

\subsection{Software}

Microsoft EXCEL Version 2003 Service Pack-2, was used for performing tabular representations and arithmetical manipulations in a spreadsheet environment. KaleidaGraph Version 4.03 was used to create the X-Y plots associated with the tabular data presented in the various sections of this report. These two commercial software packages were installed on a personal computer (PC) Dell Optiplex GX270 operating under Microsoft Windows XP operating system and are exempt from software QA and CM requirements in accordance with NSNFP 19.01, Software Control.

\subsubsection{MCNP}

The MCNP code [CRWMS 1998b] is used to calculate the $\mathrm{k}_{\text {eff }}$ of the waste package. The software specifications are as follows:

- $\quad$ Status: Qualified

- $\quad$ Software name: MCNP

- $\quad$ Software version/revision number: Version 4B2

- $\quad$ Software tracking number (computer software configuration item): 30033 V4B2LV

- $\quad$ Computer type: Hewlett-Packard (HP) 9000 Series workstations

- $\quad$ Operating system: HP-UX 10.20 and 11.00

- $\quad$ Computer processing unit number: Software is installed on the Idaho National Laboratory (INL) workstation 'homer', with property number 352667.

The MCNP software used is (a) appropriate for the application of $\mathrm{k}_{\text {eff }}$ calculations, (b) used only within the range of validation as documented in Civilian Radioactive Waste Management System management and operations [CRWMS 1998a] and Briesmeister [1997], and (c) obtained from the Software Configuration Management in accordance with LP-SI.11 Q-BSC. 
EDF-NSNF-068

Revision 0

Page 12 of 84

Title: Criticality Analysis for Proposed Maximum Fuel Loading in a Standardized SNF Canister with Type 1a Baskets

\subsubsection{SCALE 5.0}

At the time the calculations were performed using KENO V.a/TSUNAMI code from SCALE 5.0, it was recognized that the code had not been validated and verified at the INL for these scoping calculations. The INL subsequently qualified SCALE 5.0 [SQAP] and evaluated the impacts on this work. Because no changes occurred to the SCALE software, e.g. 'patches' or revisions as a result of the validation and qualification process, the NSNFP concluded that the TSUNAMI cases reported in this EDF are valid. However, the initial model analyses were processed on the PC compatible version of SCALE 5.0. Subsequent case verifications reran the models on Sun workstations after the SCALE 5.0 software qualification efforts for those computers were completed.

\section{Description of Canister and Canister Contents}

The canister configurations analyzed will contain either two or three Type 1a baskets containing ATR, MURR, MIT, or ORR SNF. Section 6.1 describes the canister. The Type 1a basket is described in Section 6.2, and each of the four fuel types are described in section 6.3.

Fuel packaging is based on fissile content proposed for repository disposal under fully degraded/moderated conditions in a post-closure scenario that is much more severe than those expected for loading, storage, or transportation. [Ref. CRWMS 2004] Gd poisoning in the basket material is installed to address these post-closure repository scenarios.

\subsection{DOE Standardized SNF Canister}

The conceptual design for the 18" standardized DOE SNF canister is taken from DOE [1999, p. 5 and A-2]. The DOE SNF canister is a right circular cylinder made from stainless steel pipe (Type 316L, Unified Numbering System [UNS] S31603) with an outside diameter of 18 in. $(457.2 \mathrm{~mm})$ and a wall thickness of $0.375 \mathrm{in} .(9.525 \mathrm{~mm})$. The minimum internal length of the short canister is $100 \mathrm{in} .(2,540.0 \mathrm{~mm})$, and the nominal overall length is $10 \mathrm{ft}$ (approximately 3,000.0 mm). There is a curved carbon steel (American Society for Testing and Materials [ASTM] A 516 Grade 70) impact plate, $50.8 \mathrm{~mm}$ (2.0 in.) thick, at the top and bottom boundaries of the canister. Dished heads seal the ends of the DOE SNF canister. The maximum loaded mass is $2,270 \mathrm{~kg}$ for the short canister [DOE 1999, Table 3.2]. A sketch of the canister is shown in Figure 6.1. 
EDF-NSNF-068

Revision 0

Page 13 of 84

Title: Criticality Analysis for Proposed Maximum Fuel Loading in a Standardized SNF Canister with Type 1a Baskets

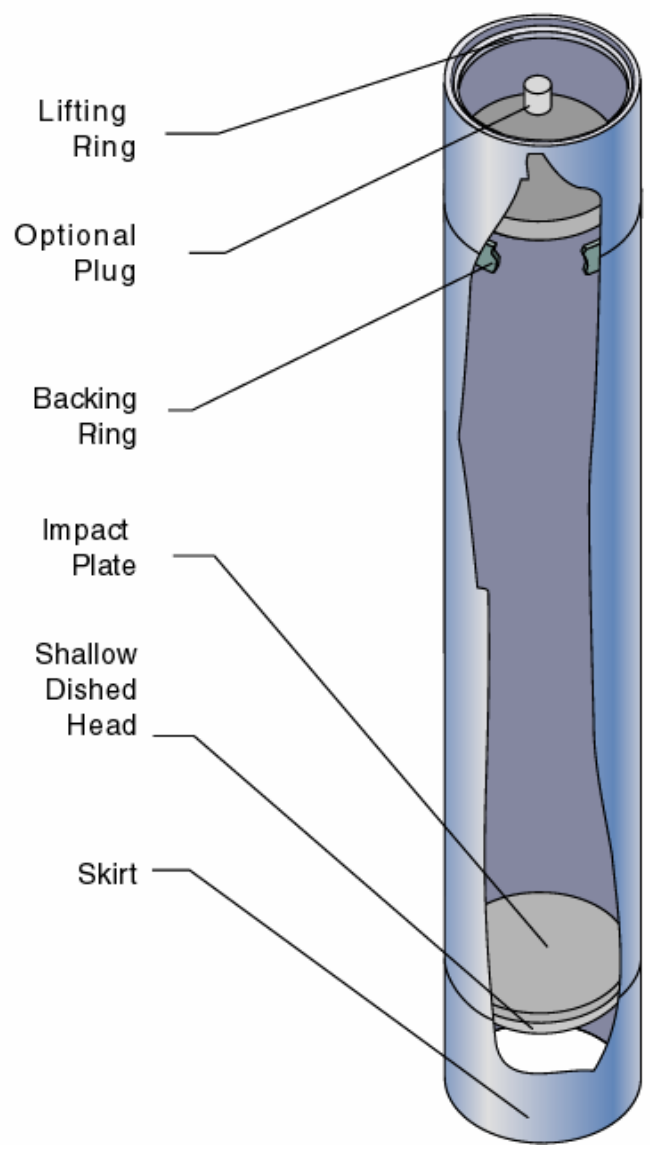

\author{
Nominal Outside Diameters: \\ 18 in. and 24 in. \\ Wall Thickness: \\ $3 / 8$ in. for 18 in. canister \\ $1 / 2$ in. for 24 in. canister \\ Maximum Weight with Fuel: \\ 5,000 to $10,000 \mathrm{lbs}$. \\ External Lengths: \\ Short Canister: 118.11 in. \\ Long Canister: 179.92 in. \\ Material: \\ Canister Body: SS316 L
}

GTO0 0119

Figure 6.1. Plan view of a typical DOE standardized SNF canister.

At the present time, use of the Type 1a basket is intended for use only in the 18-in. diameter canister. Stacking of baskets within a canister will be dictated by the individual fuel lengths and thereby determine the use of $10-\mathrm{ft}$. or $15-\mathrm{ft}$ long canisters.

\subsection{Type 1a Basket}

The DOE SNF canister typically contains a basket structure to hold the spent fuel. The basket is not a part of the DOE SNF canister. The basket structure provides material for controlling criticality, provides structural support, and acts as a guide for assemblies during loading. The basket structure to be used for packaging ATR SNF is designated as a Type 1a basket and is shown in Figures 6.2-1 and 6.2-2. Its length is specified to accommodate the length of the specific fuel to be loaded. The basket compartment dividers are made of low-C-Ni-Cr-Mo-Gd alloy (UNS N06464) with a Gd content of $2.0 \mathrm{wt} \%$ [DOE 2004b, pp. 53-55]. The basket structure contains two axial identical sections (layers) each with a circular base plate. The length of each ATR basket is 51-3/4 in. (1,341.45 mm). All Gd alloy plates and the 304L base plate used a thickness of 0.375 in. $(9.525 \mathrm{~mm})$. A cross-sectional view is shown in Figure 6.2-1 [DOE 2004b, p. 53]. The basket grid structure is surrounded by a type 304L stainless steel sleeve with an outer diameter of 16.90 in. $(429.26 \mathrm{~mm})$ and a thickness of $0.0625 \mathrm{in} .(1.587 \mathrm{~mm})$. The Type 1a basket contains 10 
Revision 0

Page 14 of 84

Title: Criticality Analysis for Proposed Maximum Fuel Loading in a Standardized SNF Canister with Type 1a Baskets

compartments. The basket compartments are defined by horizontal and vertical plates as shown in Figures 6.2-1 and 6.2.-2.

Baskets will be stacked on one another in the canister (see Figure 6.3-1). Canisters will then be seal-welded per American Society of Mechanical Engineers (ASME) Division 3 code qualifications. A similar approach will be taken with other fuels in terms of loading in a Type 1a basket. In the case of the shorter fuels, such as the MURR, MIT, and ORR fuels, the basket length will be commensurately shorter but will also be stacked three-high inside an 18-in. diameter, 10-ft long SNF canister.

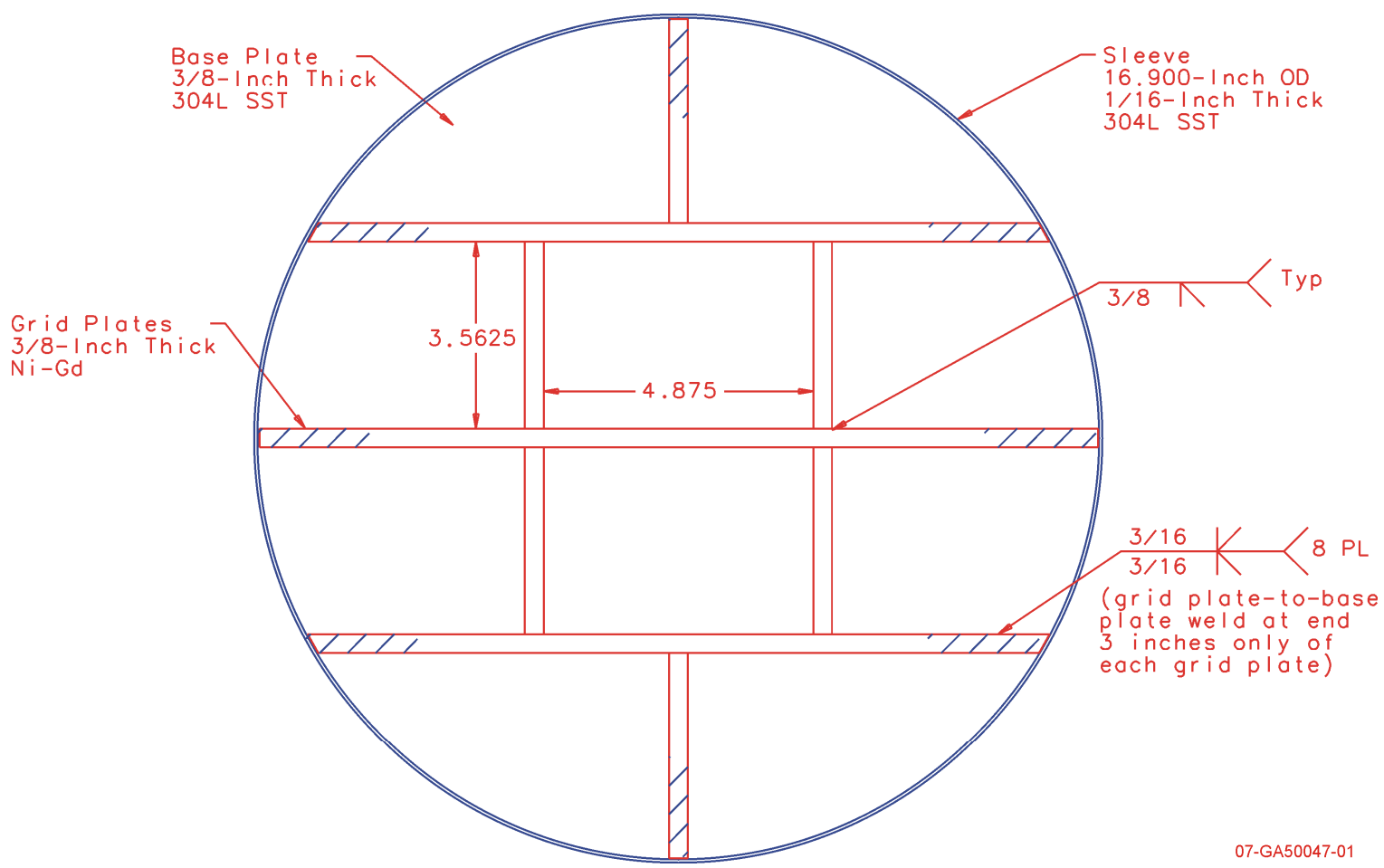

Figure 6.2-1. Cross-sectional schematic of the Type 1a basket structure and sleeve. 
NATIONAL SPENT NUCLEAR FUEL PROGRAM ENGINEERING DESIGN FILE

EDF-NSNF-068

Revision 0

Page 15 of 84

Title: Criticality Analysis for Proposed Maximum Fuel Loading in a Standardized SNF Canister with Type 1a Baskets

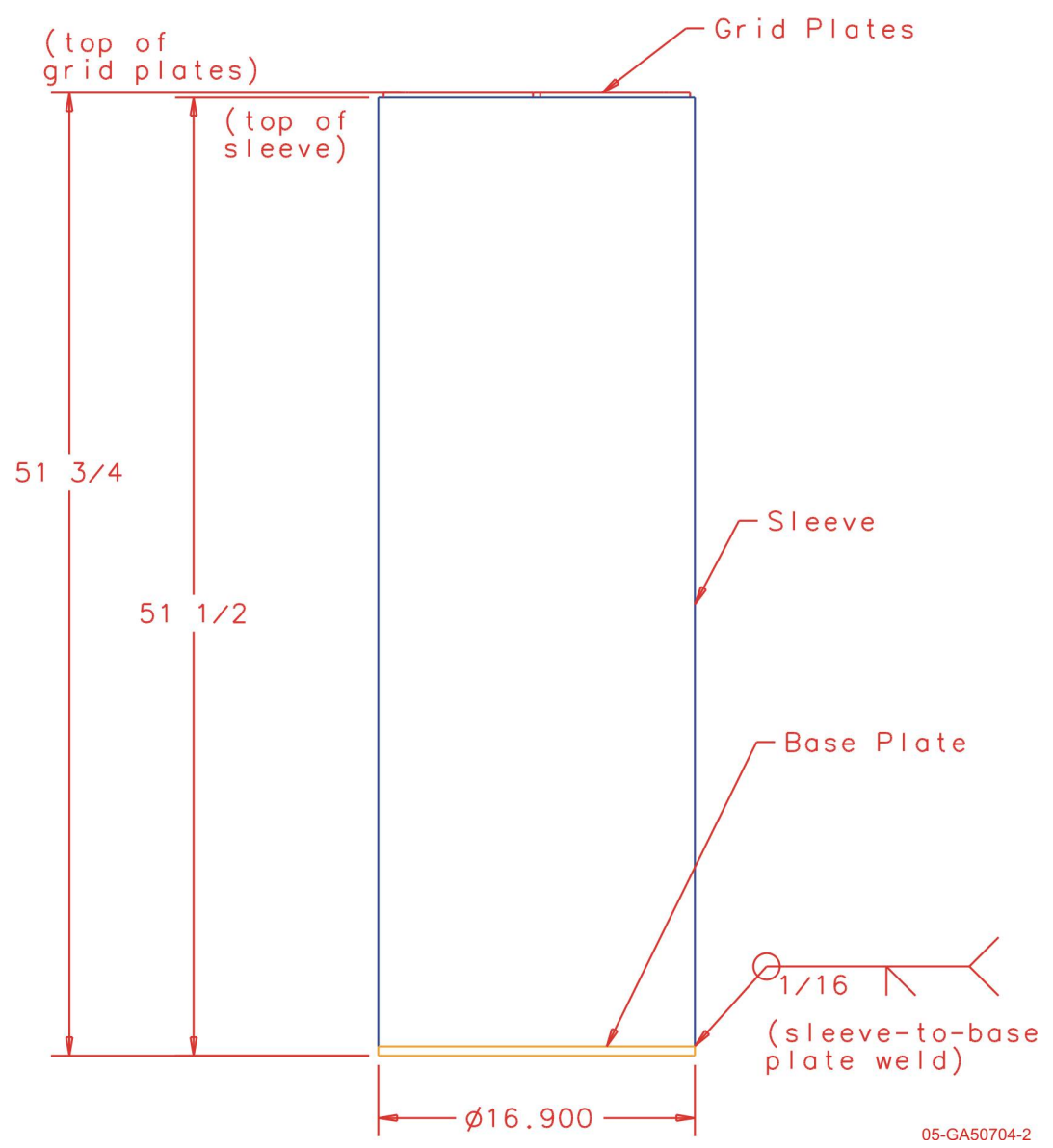

Figure 6.2-2. Type 1a SNF basket (for ATR SNF)

\subsection{Spent Nuclear Fuel}

The U.S. Department of Energy (DOE) SNF inventory is comprised of more than 250 types of fuels with differing shapes, fuel matrix compositions, fissile isotopes, cladding, and enrichments. In order to streamline the criticality analyses needed to qualify these fuels for acceptance into the national repository, the fuels were grouped by the primary common parameter of the fuel matrix material and the secondary parameter of enrichment. Packaging concepts were developed to satisfy handling requirements in the surface facility (including drop accidents) and post-closure repository conditions that included criticality analyses for waste package breaches. Eventually, the criticality analyses evolved into development of a limited number of generic basket designs, each capable of accommodating a variety of fuels based on their physical size. Regardless of the fuel type, the canister loadings, and any included poisons, are predicated on remaining below the subcritical limit for a degraded canister inside a flooded waste package in a horizontal orientation within the repository. 
Page 16 of 84

Title: Criticality Analysis for Proposed Maximum Fuel Loading in a Standardized SNF Canister with Type 1a Baskets

In the case of the fuel grouping that will be packaged into a canister using a Type 1a basket, four fuels were selected for these criticality analyses based on their fissile content and linear loading. The intent was to identify the bounding criticality analyses for these four fuel types as the basis for demonstrating criticality safety under prescribed transportation scenarios. The analyses would also identify any controls that may be necessary during canister loading to ensure that these analyses bound all loaded configurations. Prior to loading, all the different and disparate fuels identified for loading in a Type 1a basket will have to undergo their own criticality safety evaluation (CSE) based on their as-loaded condition, both dry and flooded. Specific parameters such as total fissile, linear fissile loading, calculated $\mathrm{k}_{\mathrm{eff}}$, and thermal output will have to demonstrate lesser values than those of the as-loaded, baseline ATR fuel.

A summary of the fuel loadings for these four fuels in a standardized SNF canister is shown in Table 6.3-1.

Table 6.3-1. Aluminum plate-fuel comparisons.

\begin{tabular}{|c|c|c|c|c|c|c|}
\hline Fuel identifier $\rightarrow$ & $\begin{array}{c}\text { ATR } \\
(\mathrm{HEU} / \\
\left.\mathrm{UAl}_{\mathrm{x}}\right) \\
{\left[10^{\prime}\right.} \\
\text { canister] }\end{array}$ & $\begin{array}{c}\text { ATR } \\
(\mathrm{HEU} / \\
\left.\mathrm{UAl}_{\mathrm{x}}\right)[15 \\
\text { canister] }\end{array}$ & $\begin{array}{c}\text { ORR } \\
\text { (MEU/ } \\
\text { U-Al-Si) }\end{array}$ & $\begin{array}{c}\text { ORR (HEU } \\
\left./ \mathrm{U}_{3} \mathrm{O}_{8}\right) \\
\end{array}$ & $\begin{array}{l}\text { MIT }(\mathrm{HEU} / \\
\left.\mathrm{UAl}_{\mathrm{x}}\right)\end{array}$ & $\begin{array}{l}\text { MURR } \\
(\mathrm{HEU} / \\
\left.\mathrm{UAl}{ }_{\mathrm{x}}\right) \\
\end{array}$ \\
\hline BOL \% enrichment & 93.15 & 93.15 & 20.56 & 93.15 & 93.15 & 93.15 \\
\hline Assemblies/canister & 20 & 30 & 30 & 30 & 30 & 24 \\
\hline Fissile/assembly (kg) & 1.085 & 1.085 & 0.347 & 0.300 & 0.525 & 0.783 \\
\hline Fissile/canister (kg) & 21.70 & 32.55 & 10.41 & 9.00 & 15.75 & 18.79 \\
\hline $\begin{array}{l}\text { Canister fissile linear } \\
\text { loading }(\mathrm{g} / \mathrm{cm})\end{array}$ & 78.619 & 78.619 & 41.001 & 35.447 & 62.003 & 73.990 \\
\hline $\begin{array}{l}\text { 'Homogenized' fissile } \\
\text { atom-density/ canister } \\
\text { (atom/b-cm) }\end{array}$ & $1.45 \mathrm{E}-04$ & $1.45 \mathrm{E}-04$ & $6.79 \mathrm{E}-05$ & $6.02 \mathrm{E}-05$ & $1.05 \mathrm{E}-04$ & $1.26 \mathrm{E}-04$ \\
\hline
\end{tabular}

\subsubsection{Advance Test Reactor Fuel}

The ATR fuel assemblies will be inserted in each one of 10 compartments in a Type 1a basket, and the baskets will be stacked three high in a 15' canister. Previous criticality analyses had examined ATR assemblies 'two-stacked' in a 10-ft. canister when their cropped length was quoted as $<49.5$-in. (1257.3 $\mathrm{mm}$ ). Subsequent information [FRC-0022] revealed a longer assembly length was possible, thereby necessitating longer baskets stacked three-deep in a 15 -ft. canister. This resulted in an attendant 50\% increase in the fissile load per canister, but no change in the linear fissile load. The 'three-stack' analyses examined the fuel assemblies as though they met the earlier maximum dimension of 49.5-in.; this represents the more conservative (most reactive) case with respect to neutron interaction between assemblies. 
EDF-NSNF-068

Revision 0

Page 17 of 84

Title: Criticality Analysis for Proposed Maximum Fuel Loading in a Standardized SNF Canister with Type 1a Baskets

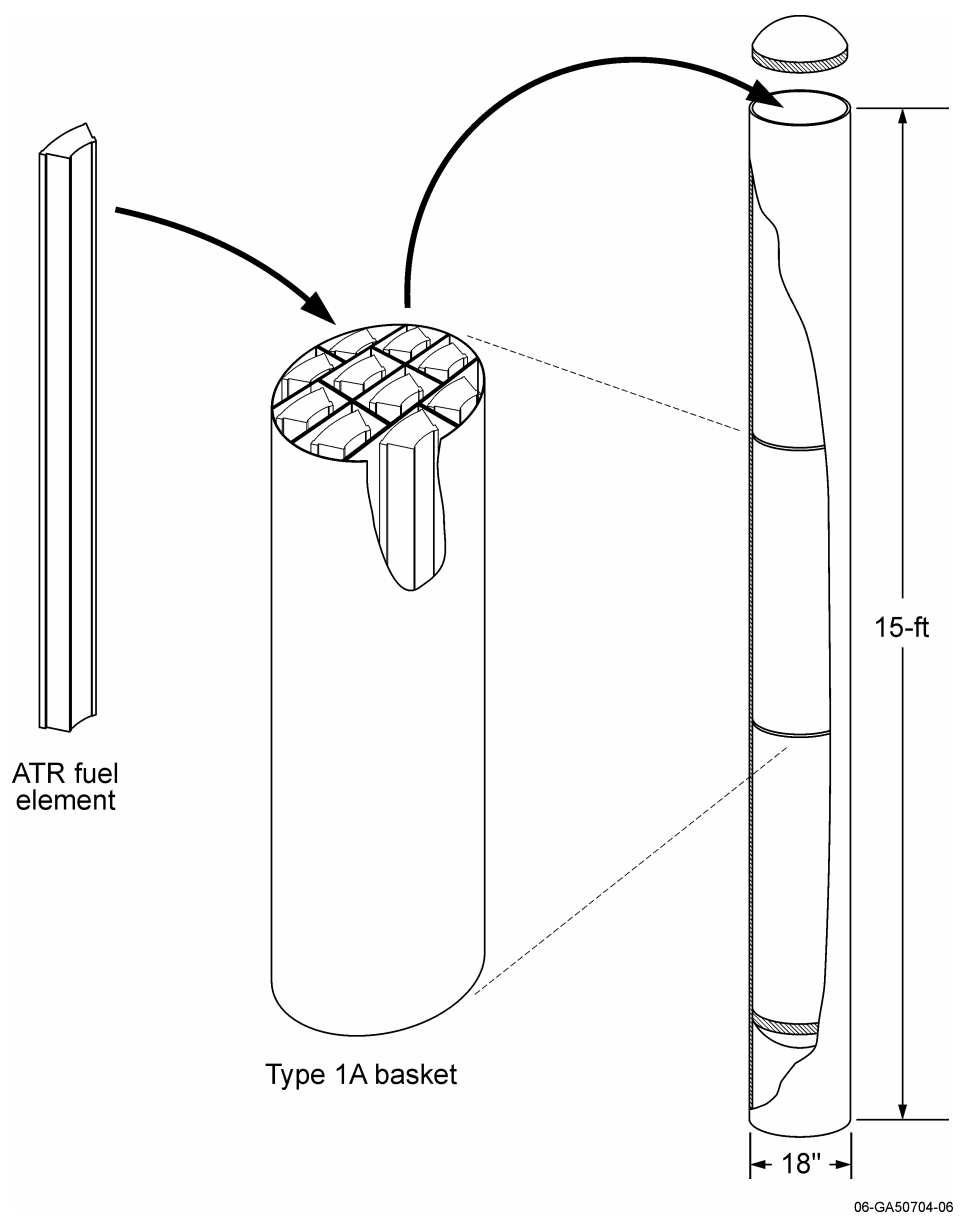

Figure 6.3-1. Conceptual canister.

A typical ATR fuel element consists of 19 curved Al-clad uranium aluminide $\left(\mathrm{UAl}_{\mathrm{x}}\right)$ plates containing highly enriched uranium (HEU) $\left(93 \pm 1 \mathrm{wt} \%{ }^{235} \mathrm{U}\right)$ [Reed et al. 1992]. The nominal fissile loading $\left({ }^{235} \mathrm{U}\right)$ of the fresh fuel element is $1,075 \mathrm{~g}$ [Paige 1969]. The allowable uncertainty in the fuel loading is $1 \%$ or $10.75 \mathrm{~g}$ [INEEL 2003]. The highest fissile loading of $1,085.75 \mathrm{~g}$ was conservatively used in the present analysis.

Figure 6.3-2 presents a simplified view of a typical ATR fuel element. The fuel elements are cropped to the length of the fuel plates by removing the upper and lower end boxes. The fuel plates are $49.5 \mathrm{in}$. (1,257.3 mm) long with a fuel zone that is $48.76 \mathrm{in}$. $(1,238.504 \mathrm{~mm})$ long. The cropped length of a fuel assembly can range from $49.5 \mathrm{in} .(1,257,30 \mathrm{~mm})$ up to $51.0 \mathrm{in}(1,295.40 \mathrm{~mm})$. [FRC-0022]

The following data are characteristics for the ATR 7F fuel elements [Paige 1969]. The thickness of each plate is $0.05 \mathrm{in} .(1.27 \mathrm{~mm})$ except plates 1 and 19 , which are $0.08 \mathrm{in} .(2.03 \mathrm{~mm})$ and $0.1 \mathrm{in}$. $(2.54 \mathrm{~mm})$, respectively. The fuel matrix section in each plate is $0.02 \mathrm{in} .(0.51 \mathrm{~mm})$ thick. The cladding is made of aluminum (T-6061). The plates are held in place by aluminum side plates that are $2.55 \mathrm{in}$. $(64.77 \mathrm{~mm})$ wide (radial thickness of the fuel assembly), $0.187 \mathrm{in.}(4.75 \mathrm{~mm})$ thick, and $49.5 \mathrm{in}$. $(1,257.3 \mathrm{~mm})$ long. When assembled, the angle of curvature of the fuel elements is $45^{\circ}$ with an inner 
Revision 0

Page 18 of 84

Title: Criticality Analysis for Proposed Maximum Fuel Loading in a Standardized SNF Canister with Type 1a Baskets

radius of $2.964 \mathrm{in} .(75.29 \mathrm{~mm})$ and an outer radius of $5.513 \mathrm{in.}(140.03 \mathrm{~mm})$. The detailed dimensions of each fuel plate and fuel matrix are presented in Table 6.1-1.

Analysis of the ATR fuels is based on the compositions provided for the ATR-7F elements from contract C-285, which requires $1,075 \mathrm{~g}{ }^{235} \mathrm{U}$ nominal and $1,085.75 \mathrm{~g}{ }^{235} \mathrm{U}$ [max] loading. The uranium loading varies by fuel plate by the following amounts:

- $\quad$ Plates $1,2,18$, and 19 at 32.5 to $33.5 \mathrm{wt} \% \mathrm{U}$

- $\quad$ Plates $3,4,16$, and 17 at 38.1 to $38.8 \mathrm{wt} \% \mathrm{U}$

- $\quad$ Plates $10,11,12,13,14$, and 15 at 44.4 to $44.6 \mathrm{wt} \% \mathrm{U}$

- $\quad$ Plates 5, 6, 7, 8, and 9 at 44.8 to $45.2 \mathrm{wt} \% \mathrm{U}$.

Element weight is comprised of type $6061 \mathrm{Al}$ side plates $(1.17 \mathrm{~kg})$, type $6061 \mathrm{Al}(0.6 \mathrm{wt} \% \mathrm{Si})$ clad and type $1100 \mathrm{Al}(0.1 \mathrm{wt} \% \mathrm{Si})$ frame $(4.42 \mathrm{~kg})$, and fuel matrix $(3.02 \mathrm{~kg})$ for a total assembly weight of $8.61 \mathrm{~kg}$. The density of the $\mathrm{T} 6061 \mathrm{Al}$ side plate is $2.7 \mathrm{~g} / \mathrm{cm}^{3}$. 
EDF-NSNF-068

Revision 0

Page 19 of 84

Title: Criticality Analysis for Proposed Maximum Fuel Loading in a Standardized SNF Canister with Type 1a Baskets

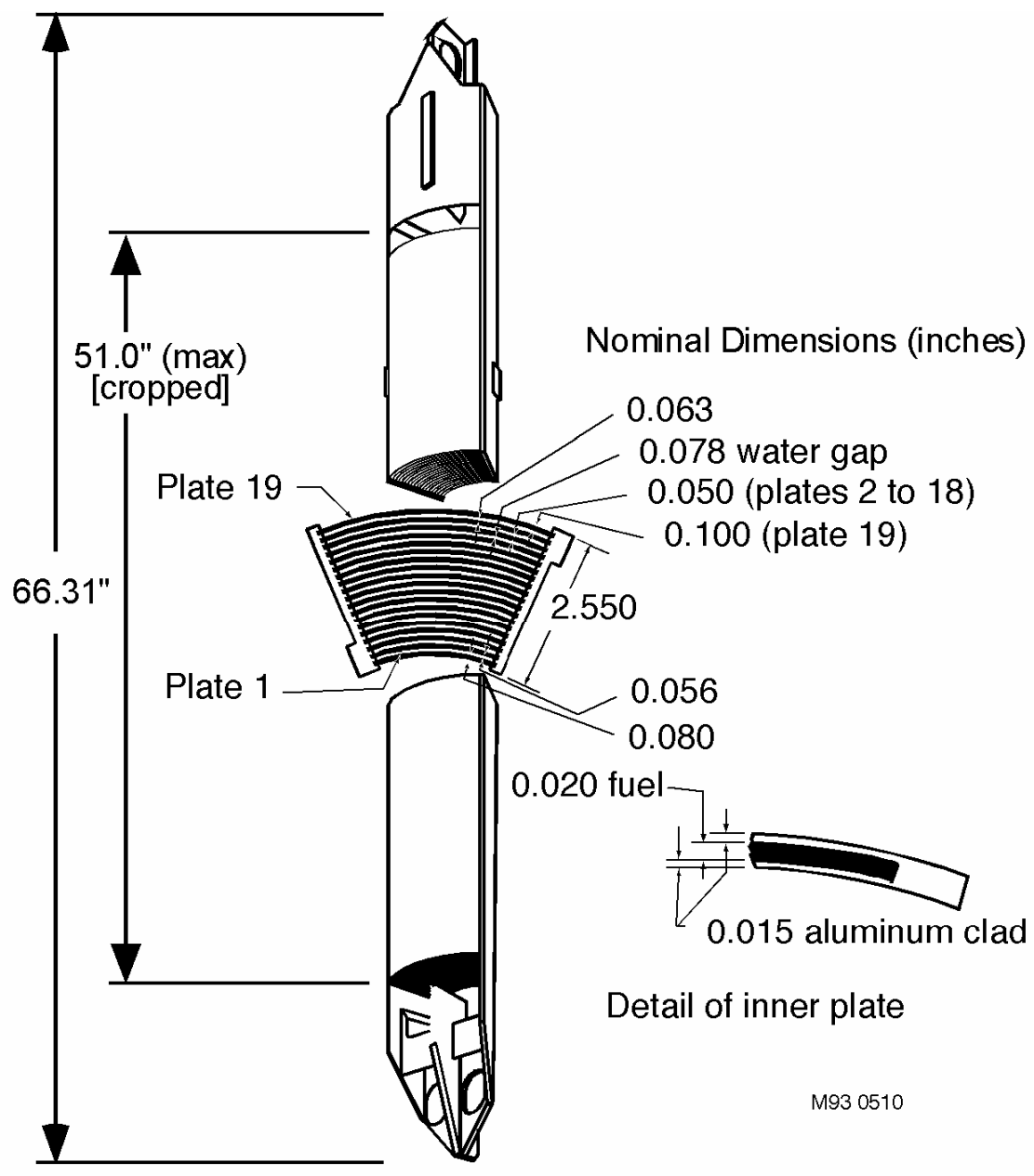

ATR Fuel

Figure 6.3-2. Simplified view of the ATR fuel element.

Table 6.3-2. Dimensions and fissile loading for individual plates in ATR fuel element.

\begin{tabular}{cccccc} 
Plate Number & $\begin{array}{c}\text { Inner Radius } \\
(\mathrm{mm})\end{array}$ & $\begin{array}{c}\text { Outer Radius } \\
(\mathrm{mm})\end{array}$ & $\begin{array}{c}\text { Plate Arc } \\
\text { Length } \\
(\mathrm{mm})\end{array}$ & $\begin{array}{c}\text { Fuel Meat Arc } \\
\text { Length } \\
(\mathrm{mm})\end{array}$ & $\begin{array}{c}{ }^{235} \text { U content, } \\
\text { gms (max })\end{array}$ \\
\hline 1 & 76.5810 & 78.6130 & 54.1020 & 41.3258 & 24.543 \\
2 & 80.5942 & 81.8642 & 55.4228 & 49.2506 & 29.391 \\
3 & 83.8454 & 85.1154 & 57.9882 & 51.8160 & 39.087 \\
4 & 87.0966 & 88.3666 & 60.5028 & 54.3306 & 40.804 \\
5 & 90.3478 & 91.6178 & 63.0936 & 56.9214 & 52.621 \\
6 & 93.5990 & 94.8690 & 65.6336 & 59.4614 & 55.146
\end{tabular}


EDF-NSNF-068

Revision 0

Page 20 of 84

Title: Criticality Analysis for Proposed Maximum Fuel Loading in a Standardized SNF Canister with Type 1a Baskets

\begin{tabular}{cccccc}
\hline Plate Number & $\begin{array}{c}\text { Inner Radius } \\
(\mathrm{mm})\end{array}$ & $\begin{array}{c}\text { Outer Radius } \\
(\mathrm{mm})\end{array}$ & $\begin{array}{c}\text { Plate Arc } \\
\text { Length } \\
(\mathrm{mm})\end{array}$ & $\begin{array}{c}\text { Fuel Meat Arc } \\
\text { Length } \\
(\mathrm{mm})\end{array}$ & $\begin{array}{c}{ }^{235} \text { U content, } \\
\text { gms (max })\end{array}$ \\
\hline 7 & 96.8502 & 98.1202 & 68.1990 & 62.0268 & 57.570 \\
8 & 100.1014 & 101.3714 & 70.7390 & 64.5668 & 59.994 \\
9 & 103.3526 & 104.6226 & 73.3044 & 67.1322 & 62.418 \\
10 & 106.6038 & 107.8738 & 75.8444 & 69.6722 & 64.842 \\
11 & 109.8550 & 111.1250 & 78.4098 & 72.2376 & 67.266 \\
12 & 113.1062 & 114.3762 & 80.9752 & 74.8030 & 69.690 \\
13 & 116.3574 & 117.6274 & 83.5152 & 77.3430 & 72.114 \\
14 & 119.6086 & 120.8786 & 86.0806 & 79.9084 & 74.538 \\
15 & 122.8598 & 124.1298 & 88.6206 & 82.4484 & 77.063 \\
16 & 126.1110 & 127.3810 & 91.1860 & 85.0138 & 64.640 \\
17 & 129.3622 & 130.6322 & 93.7260 & 87.5538 & 66.559 \\
18 & 132.6134 & 133.8834 & 96.2914 & 88.8492 & 54.338 \\
19 & 135.8646 & 138.4046 & 100.8634 & 88.0872 & 53.126 \\
\hline & & & & Total ${ }^{235} \mathrm{U}:$ & $1085.75 \mathrm{gms}$
\end{tabular}

Source: Paige (1969), ATR 7F fuel element

\subsubsection{Missouri University Research Reactor Fuel}

The details of the MURR fuel were obtained from the MURR fuel specification [DWG 237]. The MURR fuel assembly is constructed from 24 fuel plates, two side plates, two combs, and several smaller pieces of hardware (screws, nuts, pins, and rivets). The fuel plates are attached to the fuel sections by riveting. Combs are attached to the fuel plates by pinning.

The overall length of a new fuel assembly is $32.5 \mathrm{in}$. (825.50 mm) [DWG 409] [CRWMS 1997a] with a cropped length of approximately $26.5 \mathrm{in} .(673.10 \mathrm{~mm})$ [OBU 2003] after removing the top and bottom ends of the assembly, which do not contain uranium materials. Figure 6.3-3 depicts a simplified view for both length and cross section of a cropped fuel element. 
EDF-NSNF-068

Revision 0

Page 21 of 84

Title: Criticality Analysis for Proposed Maximum Fuel Loading in a Standardized SNF Canister with Type 1a Baskets
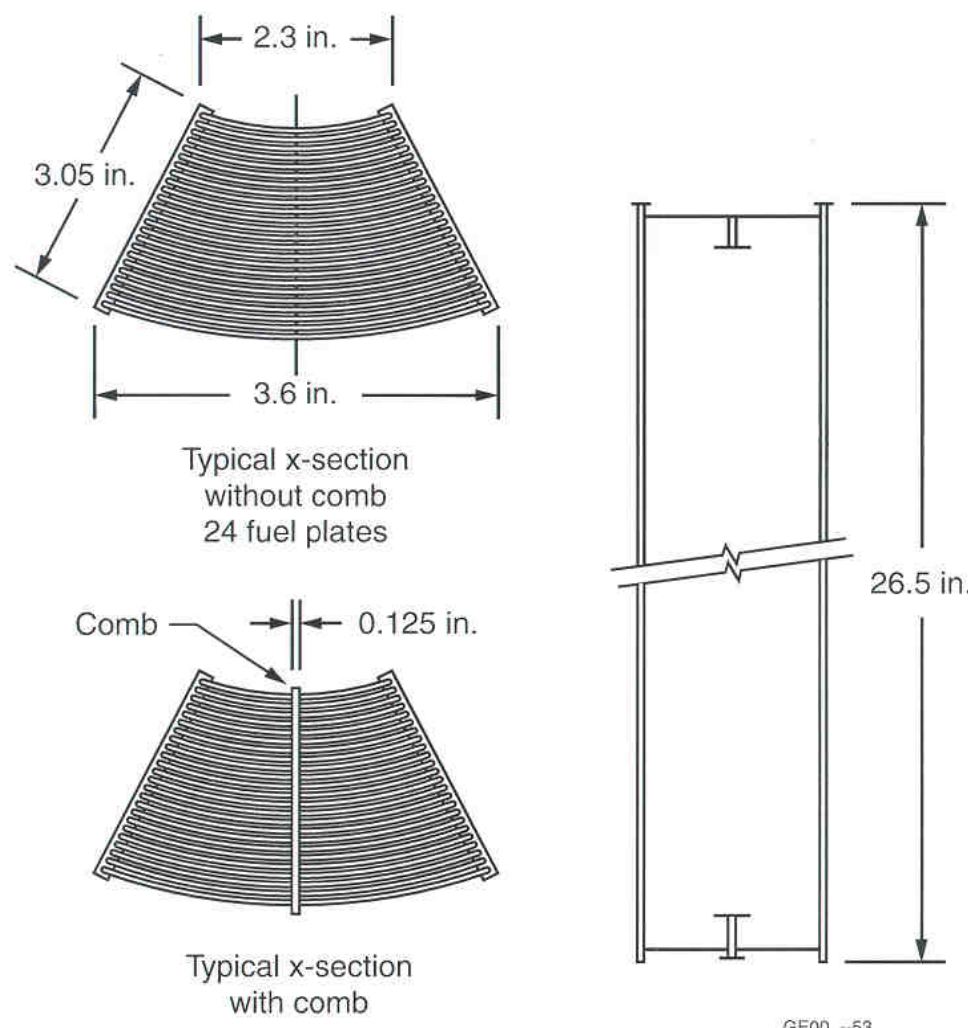

GE00_-53

Figure 6.3-3. Simplified view of the MURR fuel element (cropped length).

The fueled portion of each plate can range from 23.25 to $24.75 \mathrm{in}$. (590.55 to $628.65 \mathrm{~mm}$ ) [DWG 409]. The fuel matrix alloy is $0.020 \mathrm{in} .(0.51 \mathrm{~mm})$ thick, with an aluminum cladding thickness of 0.015 in. $(0.38 \mathrm{~mm})$, for total plate thicknesses of 0.050 in. $(1.27 \mathrm{~mm})$ [DWG 237].

The width of the individual plates is variable between 1.9929 to 4.3421 in. (50.62 to $110.29 \mathrm{~mm}$ ), because the fuel element employs $45^{\circ}$ wedge shaped construction with curved plates using an outer radius

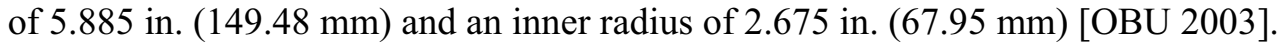

Density of the aluminum used for the fuel plate cladding is $2.7 \mathrm{~g} / \mathrm{cm}^{3}$ [CRWMS 1997a]. Table 6.33 provides the fissile loading for each plate (element) in the assembly. This fuel matrix material consists of $93 \pm 1.0 \%$ enriched $\mathrm{U}$ as a $\mathrm{UAl}_{\mathrm{x}}$ powder which is in turn dispersed in $\mathrm{Al}$ powder and sintered together. Density of this Al powder used in the fuel matrix is $2.7 \mathrm{~g} / \mathrm{cm}^{3}$ [CRWMS 1997a] and density of the $\mathrm{UAl}_{\mathrm{x}}$ matrix is $6.4 \mathrm{~g} / \mathrm{cm}^{3}$ [Knight 1993]. 
Page 22 of 84

Title: Criticality Analysis for Proposed Maximum Fuel Loading in a Standardized SNF Canister with Type 1a Baskets

Table 6.3-3. MURR fuel assembly plate details.

\begin{tabular}{|c|c|c|c|c|}
\hline $\begin{array}{c}\text { Plate/ } \\
\text { Element No. }\end{array}$ & $\begin{array}{c}\mathrm{UAl}_{\mathrm{x}}, \mathrm{Wt} . \\
(\mathrm{g}) \pm 3 \%\end{array}$ & $\begin{array}{l}\text { Al Matrix Wt. (g) } \\
\text { [excluding Al } \\
\left.\text { in } \mathrm{UAl}_{\mathrm{x}}\right]_{ \pm 3} \%\end{array}$ & $\begin{array}{c}\text { Al Clad Wt } \\
\text { (g) } \pm 5 \%\end{array}$ & $\begin{array}{c}{ }^{235} \text { U Content } \\
\text { (g) } \pm 1 \%\end{array}$ \\
\hline 1 & 29.0 & 21.0 & 80.0 & 19.260 \\
\hline 2 & 30.9 & 22.0 & 86.0 & 20.393 \\
\hline 3 & 32.7 & 23.3 & 89.0 & 21.526 \\
\hline 4 & 34.6 & 24.9 & 93.0 & 22.659 \\
\hline 5 & 36.2 & 26.3 & 100.0 & 23.793 \\
\hline 6 & 37.9 & 27.5 & 106.0 & 24.926 \\
\hline 7 & 39.5 & 28.8 & 108.0 & 26.059 \\
\hline 8 & 41.2 & 29.7 & 113.0 & 27.192 \\
\hline 9 & 43.0 & 31.4 & 116.0 & 28.325 \\
\hline 10 & 44.6 & 32.8 & 120.0 & 29.459 \\
\hline 11 & 46.6 & 33.9 & 123.0 & 30.592 \\
\hline 12 & 48.1 & 35.3 & 128.0 & 31.725 \\
\hline 13 & 49.9 & 36.6 & 131.0 & 32.858 \\
\hline 14 & 51.5 & 38.0 & 131.0 & 33.992 \\
\hline 15 & 53.3 & 38.6 & 136.0 & 35.125 \\
\hline 16 & 55.0 & 40.5 & 138.0 & 36.258 \\
\hline 17 & 56.8 & 41.0 & 138.0 & 37.391 \\
\hline 18 & 58.5 & 42.3 & 140.0 & 38.524 \\
\hline 19 & 60.2 & 43.5 & 143.0 & 39.658 \\
\hline 20 & 61.9 & 44.8 & 147.0 & 40.791 \\
\hline 21 & 63.6 & 46.0 & 150.0 & 41.924 \\
\hline 22 & 65.6 & 47.3 & 154.0 & 43.057 \\
\hline 23 & 67.3 & 48.5 & 170.0 & 44.191 \\
\hline 24 & 69.0 & 49.7 & 172.0 & 45.324 \\
\hline Totals & 1176.9 & 853.7 & 3012.0 & 775.0 \\
\hline
\end{tabular}

\subsubsection{Massachusetts Institute of Technology Fuel}

The details of the MIT fuel were obtained from CRWMS [1997b]. The MIT SNF plate/assembly drawing is found in drawing (DWG) 419486 [DWG 419]. The MIT fuel assembly is constructed from 15 flat plates tilted at a $60^{\circ}$ angle so that the resulting assembly has a rhomboidal (equilateral parallelogram with $60^{\circ}$ acute angles) cross section, instead of the more common square or partial-arc cross section. Figure 6.3-4 depicts the MIT fuel assembly. The MIT fuel length values used in these analyses are shorter than the original as-built length of the MIT assembly, because the top and bottom ends of the assembly, which do not contain uranium materials, have been removed by cutting. 
Revision 0

Page 23 of 84

Title: Criticality Analysis for Proposed Maximum Fuel Loading in a Standardized SNF Canister with Type 1a Baskets

The flat plates are $2.552+0.000,-0.002$ in. $(64.82+0.0,-0.05 \mathrm{~mm})$ wide and 23 in.

$(584.20 \mathrm{~mm})$ long. All 15 plates are the same and have a finned cladding surface with a total thickness of $0.80 \pm 0.003$ in. $(20.32 \pm 0.08 \mathrm{~mm})$ including a fin height of $0.010 \pm 0.002 \mathrm{in} .(0.25 \pm 0.05 \mathrm{~mm})$ on both faces. The fuel alloy is $0.030+0.000,-0.002$ in. $(0.76+0.0,-0.05 \mathrm{~mm})$ thick, $2.177+0.000,-0.1875 \mathrm{in}$. $(55.30+0.0,-4.76 \mathrm{~mm})$ wide, and $23.75 \pm 0.233 \mathrm{in} .(603.25 \pm 5.92 \mathrm{~mm})$ long [DWG 419].
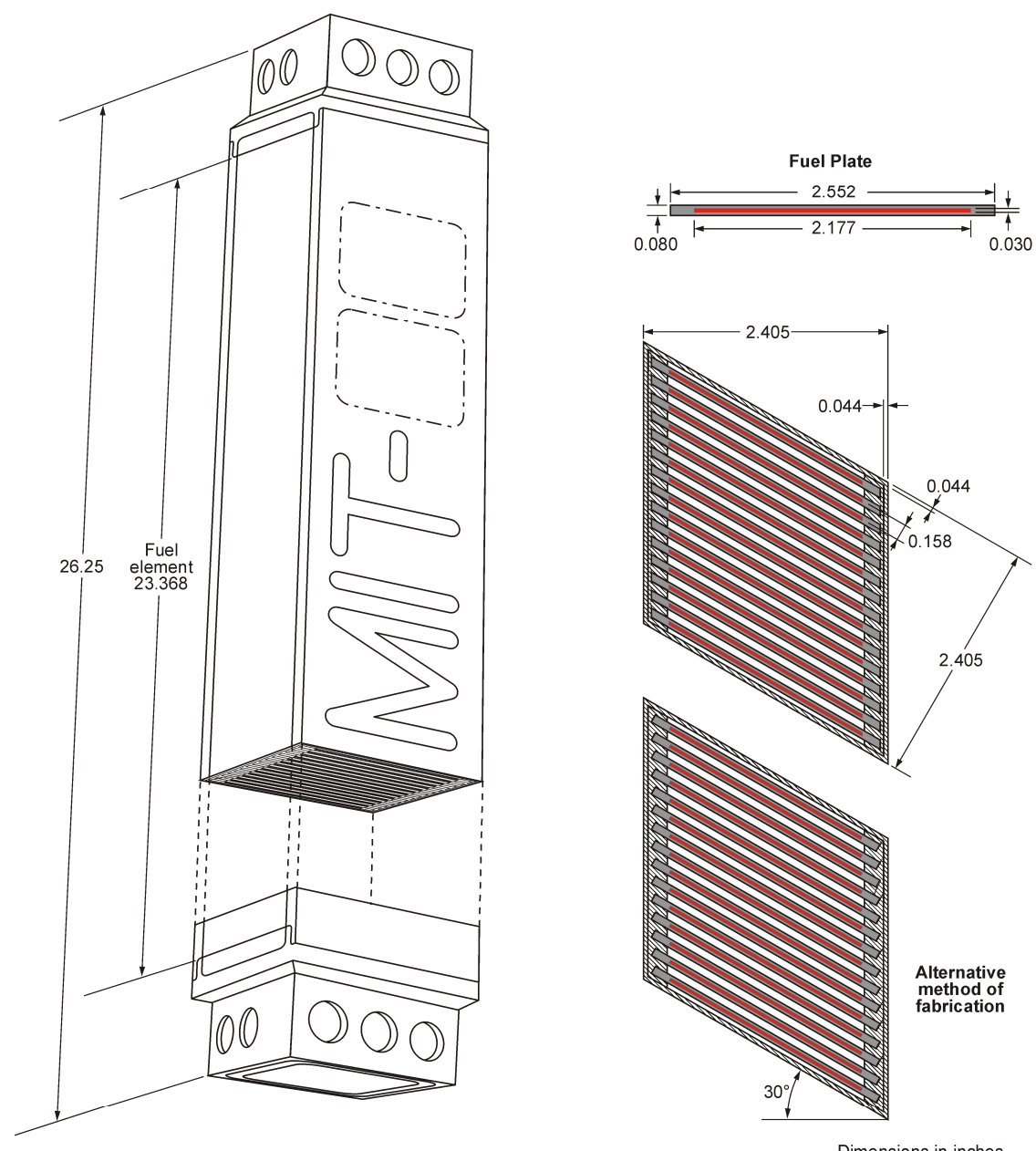

Dimensions in inches

Figure 6.3-4. Simplified view of the MIT fuel element (cropped length). 
Title: Criticality Analysis for Proposed Maximum Fuel Loading in a Standardized SNF Canister with Type 1a Baskets

The aluminum outer shroud that encloses the 15 fuel plates on 4 sides is a 2.405 in. $(61.09 \mathrm{~mm})$ outside dimension rhomboid with a $0.044 \mathrm{in.}(1.12 \mathrm{~mm})$ thick wall parallel with the fuel plates and a $0.188 \mathrm{in} .(4.78 \mathrm{~mm})$ thick comb plate at $60^{\circ}$ to the fuel plates, and a nominal length (after cutting) of $23.368 \mathrm{in} .(593.55 \mathrm{~mm})$. The fuel plates are centered within this rhomboid angled $60^{\circ}$ off the comb plate. The plates are fixed relative to each other by comb plates along two sides and the lip of the end fittings across the top and bottom. Drawing 419486 [DWG 419] shows a fuel plate center-to-center spacing of 0.158 in. $(4.01 \mathrm{~mm})$, which is the spacing of the notches on the comb plates [CRWMS 1997b].

The fuel plates consist of an aluminum cladding over $\mathrm{UAl}_{\mathrm{x}}$ alloy. The maximum fuel mass for the MIT assembly is $514.25 \mathrm{~g}$ of ${ }^{235} \mathrm{U}$ with an enrichment of $93.5 \mathrm{wt} \%$, and $1 \mathrm{wt} \%$ of $\mathrm{U}^{234}$. The fissile atomdensities are not tabulated in this case, as all the fissile material is uniformly distributed over each plate in the assembly. The $\mathrm{Al}$ present in the $\mathrm{UAl}_{\mathrm{x}}$ alloy is $30.5 \mathrm{wt} \%$. The $\mathrm{UAl}_{\mathrm{x}}$ alloy has a significant void volume if distributed over the maximum dimensions of the assembly, and thus can become waterlogged with a resultant increase in reactivity. The maximum void volume fraction in the fuel assembly, including space between the plates, is 0.6353 [CRWMS 1997b].

\subsubsection{Oak Ridge Research Reactor Fuel}

Details for the construction of the ORR fuel element are contained in drawings [OR-001], [OR003], and [OR-004]; a simplified depiction of a fuel assembly appears in Figure 6.3-5. The element is constructed from 19 curved fuel plates that are held within two opposing aluminum comb plates. The ORR fuel length values used in these analyses are shorter than the original as-built length of the ORR assembly, because the top and bottom ends of the assembly, which do not contain uranium materials, have been removed by cutting. The ORR fuel description [CRWMS 1997b] contains the material information. The maximum fuel mass used for the ORR analysis is $347 \mathrm{~g}$ (see clarification following Table 6.3-4) of ${ }^{235} \mathrm{U}$ at an enrichment of $20.56 \mathrm{wt} \%$. The uranium present in the U-Si-Al alloy is 77.5 $\mathrm{wt} \%$. There are two atoms of Si per three atoms of $\mathrm{U}$, and Al completes the bulk of the fuel material. The $\mathrm{U}-\mathrm{Si}$-Al has a significant void volume if distributed over the assembly dimensions; the maximum void volume fraction in the assembly (including plate spacing) is 0.4064 [CRWMS 1997b].

The curved plates are. $2.776+/-.01$ in. $(70.32+/-.07 \mathrm{~mm})$ maximum wide with a 5.5 in. $(139.70$ $\mathrm{mm}$ ) inner radius of curvature. Seventeen of the plates comprise the inner plates, with a thickness of 0.0494 to 0.0510 in. $(1.25$ to $1.30 \mathrm{~mm})$ and a $0.0105 \mathrm{in}$. $(0.27 \mathrm{~mm})$ minimum aluminum cladding on both sides of a $0.020 \mathrm{in}$. $(0.51 \mathrm{~mm})$ nominal fuel foil. A plate tolerance of $0.005 \mathrm{in}$. $(0.13 \mathrm{~mm})$ is the default value shown on the drawing. The two outer plates have a thickness of 0.063 to 0.066 in. (1.60 to 1.68 $\mathrm{mm})$ with a $0.018 \mathrm{in} .(0.46 \mathrm{~mm})$ minimum cladding on both sides of a $0.020 \mathrm{in} .(0.51 \mathrm{~mm})$ nominal fuel foil. The inner and outer fuel plates are manufactured as flat laminated sheets with a 2.7925 in. (70.93 $\mathrm{mm})$ minimum and $2.7955 \mathrm{in}$. $(71.01 \mathrm{~mm})$ maximum width that are formed to the $5.5 \mathrm{in} .(139.70 \mathrm{~mm})$ radius curvature. The fuel foil is not as wide as the aluminum cladding, and an aluminum strip is used to close each side of the finished fuel plate. For the inner fuel plates, the width of the fuel foil allows a 0.126 to 0.200 in. (3.20 to $5.08 \mathrm{~mm}$ ) inset from the edge of the plate on both sides. The overall length of the outer plate is 27.120 to 27.130 in. (688.85 to $689.10 \mathrm{~mm}$ ), and the fuel foil is centered within the plate longitudinally, with an inset at each end of 1.574 to 2.011 in. (39.98 to $51.08 \mathrm{~mm}$ ). The top and bottom ends of the inner and outer fuel foils are chamfered, but this trimming of the fuel material was neglected [CRWMS 1997b]. 
EDF-NSNF-068

Revision 0

Page 25 of 84

Title: Criticality Analysis for Proposed Maximum Fuel Loading in a Standardized SNF Canister with Type 1a Baskets

The aluminum comb plates enclose the 19 fuel plates on two sides, creating an approximate 3.25 in. $(82.55 \mathrm{~mm})$ by 3.00 in. $(76.20 \mathrm{~mm})$ outside dimension rectangle and a nominal length (after cutting) of $27.125 \mathrm{in} .(688.98 \mathrm{~mm})$. The fuel plates are centered within this box and form a square fuel/water region with a 3.169 in. $(80.49 \mathrm{~mm}$ ) reference dimension (the longitudinal comb plate width). The plates are fixed relative to each other by comb plates along two sides and by a comb strap across the top and bottom. Drawing M-11495-OR-003, "Misc. Details for ORR Fuel Element", shows a fuel plate edge-to-edge spacing of 0.166 in. $(4.22 \mathrm{~mm})$, which is the spacing of the notches on the comb plates [CRWMS 1997b].

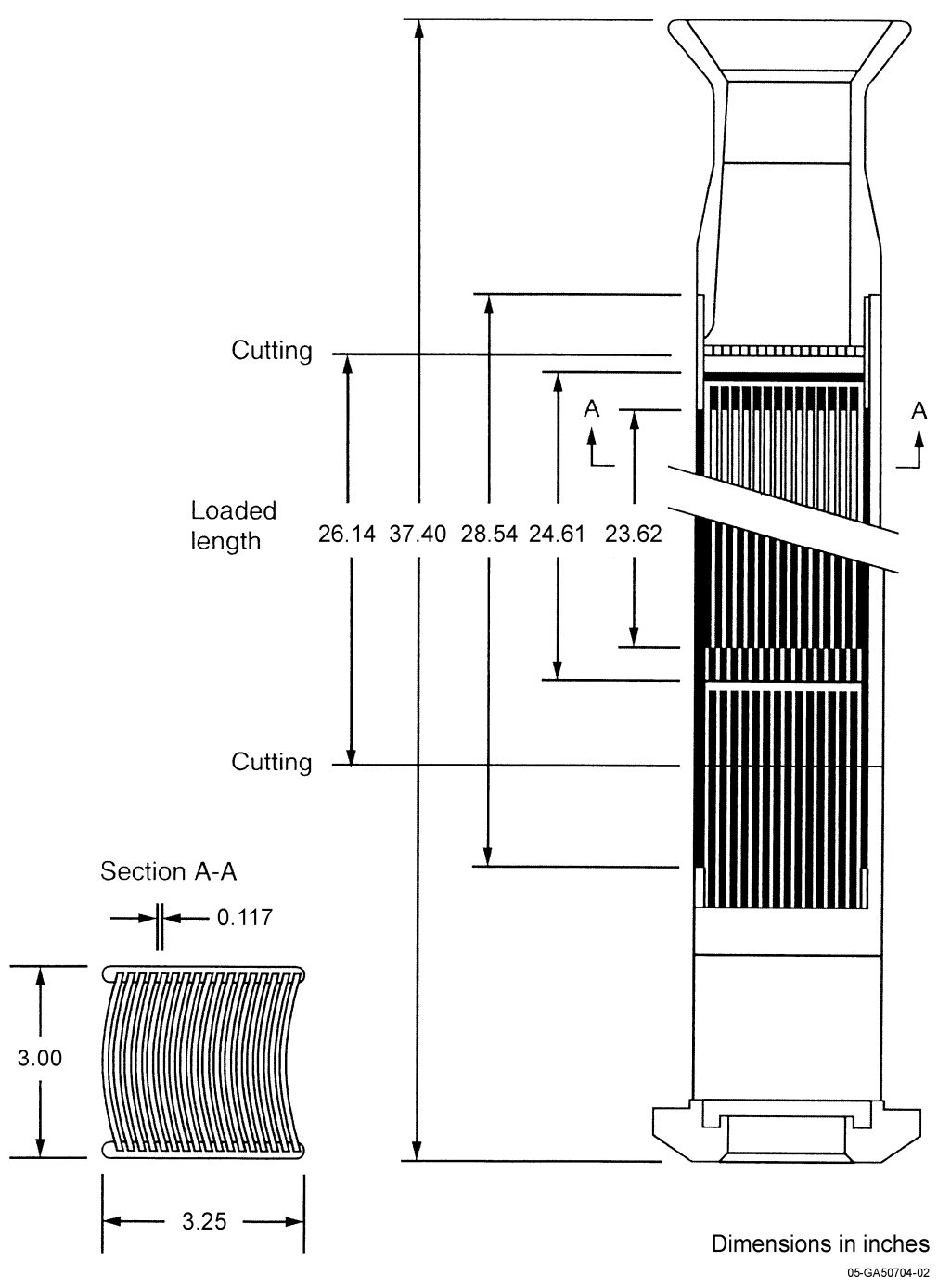

Figure 6.3-5. Simplified view of the ORR fuel element. 
EDF-NSNF-068

Revision 0

Page 26 of 84

Title: Criticality Analysis for Proposed Maximum Fuel Loading in a Standardized SNF Canister with Type 1a Baskets

The ORR fuel Appendix A [OBU 2003] contains the material information associated with these fuels. The ORR fuel is an example of the variability that can exist across a fuel group. A summary of these variables (plate count per assembly, matrix composition, or enrichment) is reflected in Table 6.3-4 [OBU 2003].

Table 6.3-4. Variability in ORR fuel types.

\begin{tabular}{|c|c|c|c|c|c|c|c|}
\hline \multirow[b]{2}{*}{ No. } & \multirow[b]{2}{*}{ Type } & \multicolumn{2}{|c|}{ *BOL (per plate) } & \multirow[b]{2}{*}{$\begin{array}{c}\text { Enrichment } \\
(\%)\end{array}$} & \multirow[b]{2}{*}{$\begin{array}{c}\text { Plates } \\
(\#)\end{array}$} & \multicolumn{2}{|c|}{ BOL (per assembly) } \\
\hline & & $\begin{array}{l}{ }^{235} \mathrm{U} \\
(\mathrm{g})\end{array}$ & $\begin{array}{c}\text { Total U } \\
(\mathrm{g})\end{array}$ & & & $\begin{array}{l}{ }^{235} \mathrm{U} \\
(\mathrm{g})\end{array}$ & $\begin{array}{c}\text { Total U } \\
(\mathrm{g})\end{array}$ \\
\hline 1 & 19 plate $\mathrm{U}_{3} \mathrm{O}_{8} \mathrm{MEU}^{* *}$ & 17.9 & 90.63 & $19.75 \%$ & 19 & 340 & 1721.5 \\
\hline 2 & 19 plate $\mathrm{U}_{3} \mathrm{O}_{8} \mathrm{HEU}^{* * *}$ & 15 & 16.13 & $92.99 \%$ & 19 & 285 & 306.47 \\
\hline 3 & 15 plate $\mathrm{U}_{3} \mathrm{O}_{8} \mathrm{HEU}$ & 11.13 & 11.97 & $92.98 \%$ & 15 & 166.95 & 179.55 \\
\hline 4 & 19 plate $\mathrm{UAl}_{\mathrm{x}} \mathrm{HEU}$ & 21.85 & 48.65 & $44.91 \%$ & 19 & 415.15 & 924.35 \\
\hline 5 & 13 plate $\mathrm{UAl}_{\mathrm{x}} \mathrm{MEU}$ & 24 & 121.21 & $19.80 \%$ & 13 & 312 & 1575.73 \\
\hline 6 & 13 plate $\mathrm{U}_{3} \mathrm{O}_{8} \mathrm{MEU}$ & 26.17 & 133.38 & $19.62 \%$ & 13 & 340.21 & 1733.94 \\
\hline 7 & 19 plate $\mathrm{U}_{3} \mathrm{Si}_{2} \mathrm{MEU}$ & 17.89 & 90.58 & $19.75 \%$ & 19 & 339.91 & 1721.02 \\
\hline 8 & 17 plate $\mathrm{U}_{3} \mathrm{Si}_{2} \mathrm{MEU}$ & 17.89 & 90.58 & $19.75 \%$ & 17 & 304.13 & 1539.86 \\
\hline 9 & 15 plate $\mathrm{U}_{3} \mathrm{Si}_{2} \mathrm{MEU}$ & 13.33 & 67.49 & $19.75 \%$ & 15 & 199.95 & 1012.35 \\
\hline 10 & 11 plate $\mathrm{U}_{3} \mathrm{Si}_{2} \mathrm{MEU}$ & 18 & 90.9 & $19.80 \%$ & 11 & 198 & 999.9 \\
\hline
\end{tabular}

The analyses done for the ORR fuels used two different fuels from this list in Table 6-17 (No. 2 and No. 6). Fuel No. 2 lists a ${ }^{235} \mathrm{U}$ content of $285 \mathrm{~g}$ assembly with a fissile enrichment of $92.99 \%$. The analysis applied an increased fissile loading of $300 \mathrm{~g}{ }^{235} \mathrm{U}$ per assembly at the same enrichment; use of this fuel in the analysis will be denoted as ORR HEU. Fuel No. 6 used $347 \mathrm{~g}{ }^{235} \mathrm{U}$ rather than the listed $340.21 \mathrm{~g}$ with its $19.62 \%$ enrichment; use of this fuel in the analysis will be denoted as ORR medium-enriched uranium (MEU). Where all of these fuels were irradiated in the same reactor using the same control rods, reactivity should be considered relatively consistent between assembly types.

\subsection{Materials Description}

Tables 6.4-1 through 6.4-6 show the composition of the material used in the models. Material nomenclature for the materials used throughout this document includes: UNS S31603 stainless steel (referred to as 316L stainless steel); UNS S31600 stainless steel (referred to as 316 stainless steel); UNS S30403 stainless steel (referred to as 304L stainless steel); UNS K02700 carbon steel (referred to as A516 Grade 70 carbon steel); UNS N06464 low-C-Ni-Cr-Mo-Gd alloy (also referred to as Ni-Gd alloy); and UNS A96061 Al (referred to as Aluminum 6061). 
Title: Criticality Analysis for Proposed Maximum Fuel Loading in a Standardized SNF Canister with Type 1a Baskets

Table 6.4-1. Composition and density of stainless steel 304L. (basket material)

\begin{tabular}{llcc}
\multicolumn{1}{c}{ Element } & $\begin{array}{c}\text { Composition } \\
(\mathrm{wt} \%)\end{array}$ & $\begin{array}{c}\text { Value Used } \\
(\mathrm{wt} \%)\end{array}$ & $\begin{array}{c}\text { Number Density } \\
\text { [atom/(cm.b)] }\end{array}$ \\
\hline Carbon (C) & 0.03 (max.) & 0.03 & $1.1943 \mathrm{E}-04$ \\
Manganese (Mn) & 2.00 (max.) & 2.00 & $1.7407 \mathrm{E}-03$ \\
Phosphorus (P) & 0.045 (max.) & 0.045 & $6.9467 \mathrm{E}-05$ \\
Sulfur (S) & 0.03 (max.) & 0.03 & $4.4869 \mathrm{E}-05$ \\
Silicon (Si) & 0.75 (max.) & 0.75 & $1.2769 \mathrm{E}-03$ \\
Chromium (Cr) & $18.00-20.00$ & 19.00 & $1.7472 \mathrm{E}-02$ \\
Nickel (Ni) & $8.00-12.00$ & 10.00 & $8.1467 \mathrm{E}-03$ \\
Nitrogen (N) & 0.1 & 0.10 & $3.4138 \mathrm{E}-04$ \\
Iron (Fe) & Balance & 68.045 & $5.8262 \mathrm{E}-02$ \\
\hline $\begin{array}{l}\text { Source: ASTM A 240/a 240M-97a, p.2. (UNS S30403) } \\
\text { Density = 7.94 g/cm }{ }^{3} \text {. }\end{array}$ & & \\
\hline
\end{tabular}

Table 6.4-2. Composition and density of stainless steel 316L. (canister material)

\begin{tabular}{lccc}
\multicolumn{1}{c}{ Element } & $\begin{array}{c}\text { Composition } \\
(\mathrm{wt} \%)\end{array}$ & $\begin{array}{c}\text { Value Used } \\
(\mathrm{wt} \%)\end{array}$ & $\begin{array}{c}\text { Number Density } \\
{[\text { atom/(cm.b) }}\end{array}$ \\
\hline Carbon (C) & 0.03 (max.) & 0.03 & $1.2003 \mathrm{E}-04$ \\
Manganese (Mn) & 2.00 (max.) & 2.00 & $1.7495 \mathrm{E}-03$ \\
Phosphorus (P) & 0.045 (max.) & 0.045 & $6.9819 \mathrm{E}-05$ \\
Sulfur (S) & 0.03 (max.) & 0.03 & $4.5092 \mathrm{E}-05$ \\
Silicon (Si) & 1.00 (max.) & 1.0 & $1.7111 \mathrm{E}-03$ \\
Chromium (Cr) & $16.00-18.00$ & 17.00 & $1.5712 \mathrm{E}-02$ \\
Nickel (Ni) & $10.00-14.00$ & 12.00 & $9.8253 \mathrm{E}-03$ \\
Molybdenum (Mo) & $2.00-3.00$ & 2.50 & $1.2523 \mathrm{E}-03$ \\
Nitrogen (N) & 0.10 (max.) & 0.10 & $3.4310 \mathrm{E}-04$ \\
Iron (Fe) & Balance & 65.295 & $5.6189 \mathrm{E}-02$ \\
\hline Source: ASTM A 276-91a, p.2 (UNS S31603) & & \\
Density = 7.98 g/cm ${ }^{3}$. & & & \\
\hline
\end{tabular}


Revision 0

Page 28 of 84

Title: Criticality Analysis for Proposed Maximum Fuel Loading in a Standardized SNF Canister with Type 1a Baskets

Table 6.4-3. Composition and density of carbon steel A516 Grade 70 (canister impact plates)

\begin{tabular}{llcc}
\multicolumn{1}{c}{ Element } & \multicolumn{1}{c}{$\begin{array}{c}\text { Composition } \\
(\mathrm{wt} \%)\end{array}$} & $\begin{array}{c}\text { Value Used } \\
(\mathrm{wt} \%)\end{array}$ & $\begin{array}{c}\text { Number Density } \\
{[\text { atom/(cm.b)] }}\end{array}$ \\
\hline Carbon (C) & 0.30 (max.) & 0.30 & $1.1021 \mathrm{E}-03$ \\
Manganese (Mn) & $0.85-1.20$ & 1.025 & $8.9921 \mathrm{E}-04$ \\
Phosphorous (P) & 0.035 max.) & 0.035 & $5.3419 \mathrm{E}-05$ \\
Sulfur (s) & 0.035 (max.) & 0.035 & $5.1751 \mathrm{E}-05$ \\
Silicon (Si) & $0.15-0.40$ & 0.275 & $4.8813 \mathrm{E}-04$ \\
Iron (Fe) & Balance & 98.33 & $8.3225 \mathrm{E}-02$ \\
\hline
\end{tabular}

Source: ASTM A 516/A 516M-90, Table 1 (UNS K02700); >2" to 4" thick plate Density $=7.85 \mathrm{~g} / \mathrm{cm}^{3}$.

Table 6.4-4. Composition and density of Ni-Gd alloy. (poison material in basket grid)

\begin{tabular}{|c|c|c|}
\hline Element & $\begin{array}{c}\text { Composition (Value Used) } \\
(\mathrm{wt} \%)\end{array}$ & $\begin{array}{l}\text { Number Density } \\
{[\text { atom } /(\mathrm{cm} \cdot \mathrm{b})]}\end{array}$ \\
\hline $\mathrm{Gd}$ & 2 & $6.7096 \mathrm{E}-04$ \\
\hline Mo & 14.55 & $8.0005 \mathrm{E}-03$ \\
\hline $\mathrm{Cr}$ & 15.8 & $1.6030 \mathrm{E}-02$ \\
\hline $\mathrm{Fe}$ & 1 & $9.4465 \mathrm{E}-04$ \\
\hline $\mathrm{Co}$ & 1 & $8.9515 \mathrm{E}-04$ \\
\hline $\mathrm{Ni}$ & 65.65 & $5.9007 \mathrm{E}-02$ \\
\hline $\begin{array}{l}\text { Density }=8.73 \mathrm{~g} / \mathrm{cn} \\
\text { Source: ASTM B } 9 \\
\end{array}$ & Table 1 (UNS N06464). & \\
\hline
\end{tabular}

Table 6.4-5. Composition and density of Aluminum 6061. (cladding material)

\begin{tabular}{lll}
\hline Element & $\begin{array}{c}\text { Composition } \\
(\mathrm{wt} \%)\end{array}$ & $\begin{array}{c}\text { Value Used } \\
(\mathrm{wt} \%)\end{array}$ \\
\hline $\mathrm{Mg}$ & $0.8-1.2$ & 1 \\
$\mathrm{Si}$ & $0.4-0.8$ & 0.6 \\
$\mathrm{Fe}$ & $0.7(\max )$ & 0.7 \\
$\mathrm{Cu}$ & $0.15-0.4$ & 0.275 \\
$\mathrm{Cr}$ & $0.04-0.35$ & 0.195 \\
$\mathrm{Mn}$ & $0.15(\max )$ & 0.15 \\
$\mathrm{Zn}$ Note a & $0.25(\max )$ & 0.25 \\
$\mathrm{Ti}$ & $0.15(\max )$ & 0.15 \\
$\mathrm{Al}$ & Balance & 96.68 \\
\hline
\end{tabular}


Title: Criticality Analysis for Proposed Maximum Fuel Loading in a Standardized SNF Canister with Type 1a Baskets

\begin{tabular}{|c|c|c|}
\hline Element & $\begin{array}{c}\text { Composition }^{\mathrm{a}} \\
(\mathrm{wt} \%)\end{array}$ & $\begin{array}{l}\text { Value Used } \\
\left(w t^{0} \%\right)\end{array}$ \\
\hline \multicolumn{3}{|c|}{$\begin{array}{l}\text { Density }{ }^{\mathrm{b}}=2.7065 \mathrm{~g} / \mathrm{cm}^{3} \\
\text { Source: a. ASM International 1990, p. 102; b. ASTM G 1-90, Table X1 indicates } 2.7 \\
\mathrm{~g} / \mathrm{cm}^{3} ; \text { ASME 2001, Section II, Table NF-2 indicates a converted value from } 0.098 \mathrm{lb} / \mathrm{in}^{3}{ }^{3} \\
\text { of } 2.713 \mathrm{~g} / \mathrm{cm}^{3} \text {; therefore, the midpoint was used. }\end{array}$} \\
\hline NOTE: See Assun & & \\
\hline
\end{tabular}

Table 6.4-6. ATR fuel number densities used in this report.

Number densities used in this evaluation $[$ atom $/(\mathrm{cm} \cdot \mathrm{b})]$

\begin{tabular}{|c|c|c|c|c|}
\hline Plate No. & ${ }^{235} \mathrm{U}$ & ${ }^{238} \mathrm{U}$ & ${ }^{234} \mathrm{U}$ & $\mathrm{Al}$ \\
\hline 1 & $2.5677 \mathrm{E}-03$ & $1.0917 \mathrm{E}-04$ & $3.2902 \mathrm{E}-05$ & $5.0781 \mathrm{E}-02$ \\
\hline 2 & $2.4883 \mathrm{E}-03$ & $1.0580 \mathrm{E}-04$ & $3.1885 \mathrm{E}-05$ & $5.0875 \mathrm{E}-02$ \\
\hline 3 & $3.1422 \mathrm{E}-03$ & $1.3360 \mathrm{E}-04$ & 4.0264E-05 & $5.0098 \mathrm{E}-02$ \\
\hline 4 & $3.1228 \mathrm{E}-03$ & $1.3277 \mathrm{E}-04$ & 4.0015E-05 & $5.0121 \mathrm{E}-02$ \\
\hline 5 & $3.8426 \mathrm{E}-03$ & $1.6338 \mathrm{E}-04$ & 4.9239E-05 & $4.9266 \mathrm{E}-02$ \\
\hline 6 & $3.8506 \mathrm{E}-03$ & $1.6372 \mathrm{E}-04$ & 4.9341E-05 & 4.9256E-02 \\
\hline 7 & $3.8512 \mathrm{E}-03$ & $1.6374 \mathrm{E}-04$ & 4.9348E-05 & 4.9256E-02 \\
\hline 8 & $3.8517 \mathrm{E}-03$ & $1.6377 \mathrm{E}-04$ & 4.9355E-05 & $4.9255 \mathrm{E}-02$ \\
\hline 9 & $3.8522 \mathrm{E}-03$ & $1.6379 \mathrm{E}-04$ & 4.9361E-05 & 4.9255E-02 \\
\hline 10 & $3.8526 \mathrm{E}-03$ & $1.6381 \mathrm{E}-04$ & 4.9367E-05 & 4.9254E-02 \\
\hline 11 & $3.8531 \mathrm{E}-03$ & $1.6383 \mathrm{E}-04$ & 4.9372E-05 & 4.9253E-02 \\
\hline 12 & $3.8535 \mathrm{E}-03$ & $1.6384 \mathrm{E}-04$ & 4.9378E-05 & 4.9253E-02 \\
\hline 13 & $3.8538 \mathrm{E}-03$ & $1.6386 \mathrm{E}-04$ & 4.9383E-05 & 4.9253E-02 \\
\hline 14 & $3.8542 \mathrm{E}-03$ & $1.6387 \mathrm{E}-04$ & 4.9387E-05 & 4.9252E-02 \\
\hline 15 & $3.8596 \mathrm{E}-03$ & $1.6410 \mathrm{E}-04$ & 4.9456E-05 & 4.9246E-02 \\
\hline 16 & $3.1388 \mathrm{E}-03$ & $1.3346 \mathrm{E}-04$ & $4.0220 \mathrm{E}-05$ & $5.0102 \mathrm{E}-02$ \\
\hline 17 & $3.1365 \mathrm{E}-03$ & $1.3336 \mathrm{E}-04$ & 4.0190E-05 & $5.0105 \mathrm{E}-02$ \\
\hline 18 & $2.5232 \mathrm{E}-03$ & $1.0728 \mathrm{E}-04$ & $3.2331 \mathrm{E}-05$ & $5.0834 \mathrm{E}-02$ \\
\hline 19 & $2.5234 \mathrm{E}-03$ & $1.0729 \mathrm{E}-04$ & $3.2334 \mathrm{E}-05$ & $5.0834 \mathrm{E}-02$ \\
\hline
\end{tabular}


Page 30 of 84

Title: Criticality Analysis for Proposed Maximum Fuel Loading in a Standardized SNF Canister with Type 1a Baskets

Fuel constituents such as boron are not included. The fissile number densities represent a slightly increased value for incorporating added conservatism into the model, e.g. 94\% enrichment with $1085.75 \mathrm{~g}$ ${ }^{235} \mathrm{U}$ per assembly.

\section{Calculations}

This section describes the calculations performed to evaluate the $\mathrm{k}_{\text {eff }}$ of a sealed SNF canister containing one or more Type 1a baskets containing either ATR, MURR, MIT, or ORR fuels. Section 6.1 and 6.2 provide the details of the SNF canister and canister basket respectively. Section 6.3 covered the various fuels and their characteristics. Section 6.4 gives the composition of the materials used in the following calculations. The basic formulas used in these calculations are listed in Section 7.1. The intact, loaded configurations of the SNF canisters are outlined in Section 7.2, and Section 7.3 describes the various degraded conditions of the SNF canister internals that were evaluated.

Avogadro's number and atomic weights are from the chart of the radionuclides in Parrington et al. [1996]. The number of digits in the values cited here may be the result of a calculation or may reflect the input from another source; consequently, the number of digits should not be interpreted as an indication of accuracy. The metric units used in this document are calculated using the English units given in the cited references. The differences that might exist between the metric units calculated and any metric units cited in references have negligible effect on the calculations, and should not be interpreted as an indication of accuracy.

\subsection{Formulas}

The basic equation used to calculate the number density values for materials composed of one or more elements/isotopes is shown below. It is used in the calculations used to produce the results summarized in the section 7:

$$
N_{i}=\left(m_{i} / m\right) * \rho * N_{a} / M_{i}=\left(V_{i} / V\right) * \rho_{i} * N_{\mathrm{a}} / M_{i}
$$

Where:

$$
\begin{aligned}
& N_{i}=\text { the number density in atoms } / \mathrm{cm}^{3} \text { of the } i^{\text {th }} \text { element/isotope } \\
& m_{i}=\text { the mass in grams of the } i^{t h} \text { element/isotope in the material } \\
& m \quad=\quad \text { the mass in grams of the material; note that } m=\sum_{i} \\
& N_{a}=\text { the Avogadro's number }\left(6.022 * 10^{23}\right. \text { atoms/mole [Parrington et al. 1996, p. 59]) } \\
& M_{i}=\text { the atomic mass in } \mathrm{g} / \text { mole of the } i^{\text {th }} \text { element/isotope } \\
& M \quad=\quad \text { the atomic mass in } \mathrm{g} / \mathrm{mole} \text { of the material } \\
& V_{i}=\text { the volume in } \mathrm{cm}^{3} \text { of the } \mathrm{i}^{\text {th }} \text { element/isotope in the material }
\end{aligned}
$$


Page 31 of 84

Title: Criticality Analysis for Proposed Maximum Fuel Loading in a Standardized SNF Canister with Type 1a Baskets

$$
\begin{aligned}
& V \quad=\text { the volume in } \mathrm{cm}^{3} \text {; note that } V=\sum_{V_{i}} \\
& \rho_{i}=\text { the density of the } i^{\text {th }} \text { element/isotope }\left(\mathrm{g} / \mathrm{cm}^{3}\right) \\
& \rho \quad=\quad \text { the density of the material }\left(\mathrm{g} / \mathrm{cm}^{3}\right) \text {; note that } \rho=\sum \rho_{i} *\left(V_{i} / V\right) .
\end{aligned}
$$

Volumes of cylinder segments (volume $=$ area of circle segment $\mathrm{x}$ length of the cylinder) are also calculated, based on the equation for the area of a segment of a circle shown below [Beyer 1987, p. 125]:

$$
\text { Area of a segment of a circle }=\left(R^{2} \cos ^{-1}\left(\frac{R-h}{R}\right)-(R-h) \sqrt{2 R h-h^{2}}\right)
$$

Where:

$$
\begin{aligned}
& R=\quad \text { the cylinder radius } \\
& h=\quad \text { the height of the segment. }
\end{aligned}
$$

\section{2 “As-Loaded” Configurations}

In the "as-loaded" configuration, the fuel, the canister, and its internal components are considered to be in their intended configuration. Modeling of the end structure of the DOE SNF canister treats both the impact plate and the dished head as a single piece that serves as an end reflector. The curved gap between the impact plate and the dished head is conservatively modeled as filled with carbon steel. Unless noted otherwise, the unoccupied spaces inside the DOE SNF canister are dry with the exception of an assumed water-logging of the fuel matrices - see Assumption 4.5.

Figure 7.2-1 presents a cross-sectional view of the baseline intact ATR (20) configuration modeled with MCNP. Figures 7.2-2 through 7.2-4 reflect the baseline model configuration for the other aluminum plate fuels in their as-loaded configurations inside a Type 1a basket. For conservatism, the fuels are placed artificially close to one another in the basket compartments for calculating maximum reactivity. Reality suggests a less optimal positioning of the fuel assemblies within the basket compartments at time of loading.

Analyses address the as-loaded configuration for single-canister scenarios, and three different scenarios involving an array of canisters in a hypothetical transportation cask (see section 7.4).

The results presented in Table 7.2-1 and Figures 7.2-1 through 7.2-4 show the relatively insignificant reactivities for single canisters, even when water-reflected. Both fuel and canister baskets are intact in these baseline analyses. The table and figures also show the small increase to single canister reactivity with the omission of Gd inside a water reflected canister. 
Revision 0

Page 32 of 84

Title: Criticality Analysis for Proposed Maximum Fuel Loading in a Standardized SNF Canister with Type 1a Baskets

The loading of the MURR fuels will utilize a Type 1a basket configuration that precludes loading the assemblies in the two center compartments (the MURR (24) center void). The results of these analyses are plotted in Figure 7.2-5.

Table 7.2-1. Water-reflected, loaded SNF canister with dry/intact internals.

\begin{tabular}{lcccc}
\multicolumn{1}{c}{ Fuel Type } & Code Case with Gd & $\mathrm{k}_{\mathrm{eff}}+2 \sigma$ & Code Case without Gd & $\mathrm{k}_{\mathrm{eff}}+2 \sigma$ \\
\hline ATR $\left(20^{*}\right)$ & atr20.o & 0.1341 & atr20-nogd.o & 0.1825 \\
ATR $\left(30^{* *}\right)$ & atr30.o & 0.1367 & atr30-nogd.o & 0.1857 \\
MURR $\left(24^{*}\right)$ & mu24c.o & 0.1583 & mu24c-nogd.o & 0.2016 \\
MIT $\left(30^{*}\right)$ & mit30.o & 0.1277 & mit30-nogd.o & 0.1742 \\
ORR-HEU $\left(30^{*}\right)$ & orr30.o & 0.1115 & orr30-nogd.o & 0.1549 \\
* SNF count in a 10-ft canister & & & & \\
** SNF count in a 15-ft canister & & & &
\end{tabular}

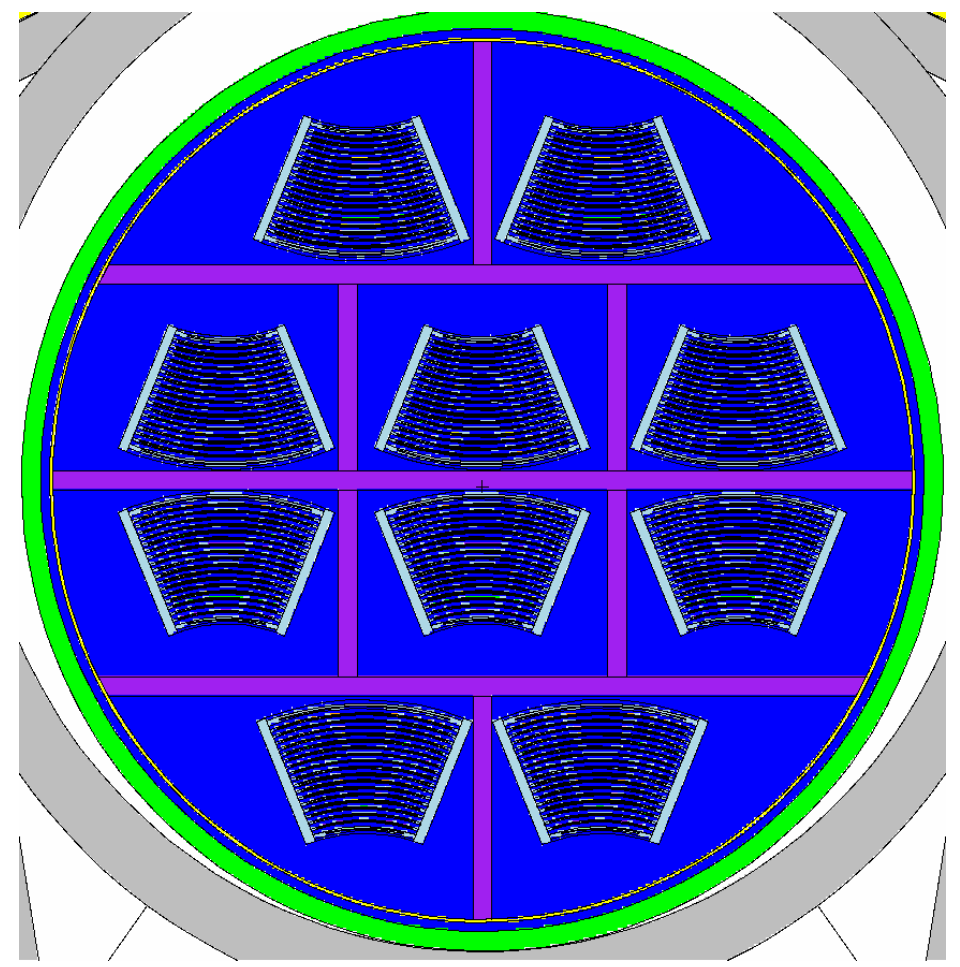

Figure 7.2-1. ATR fuel assemblies in a Type 1a basket. 
Revision 0

Page 33 of 84

Title: Criticality Analysis for Proposed Maximum Fuel Loading in a Standardized SNF Canister with Type 1a Baskets

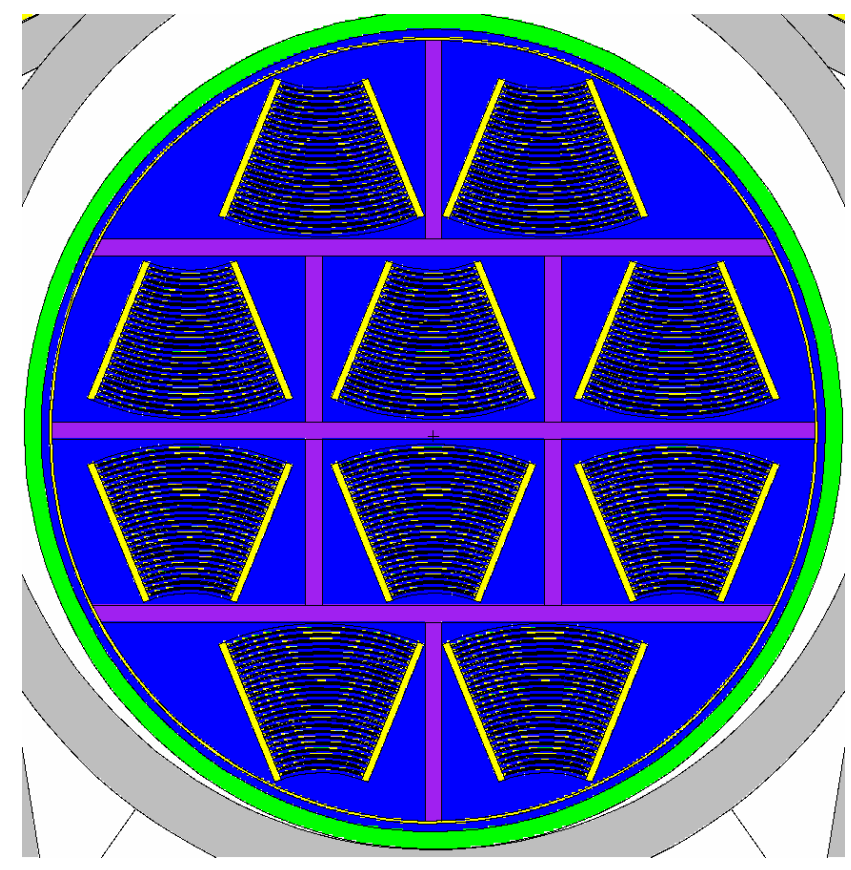

Figure 7.2-2. MURR fuel assemblies in a Type 1a basket.

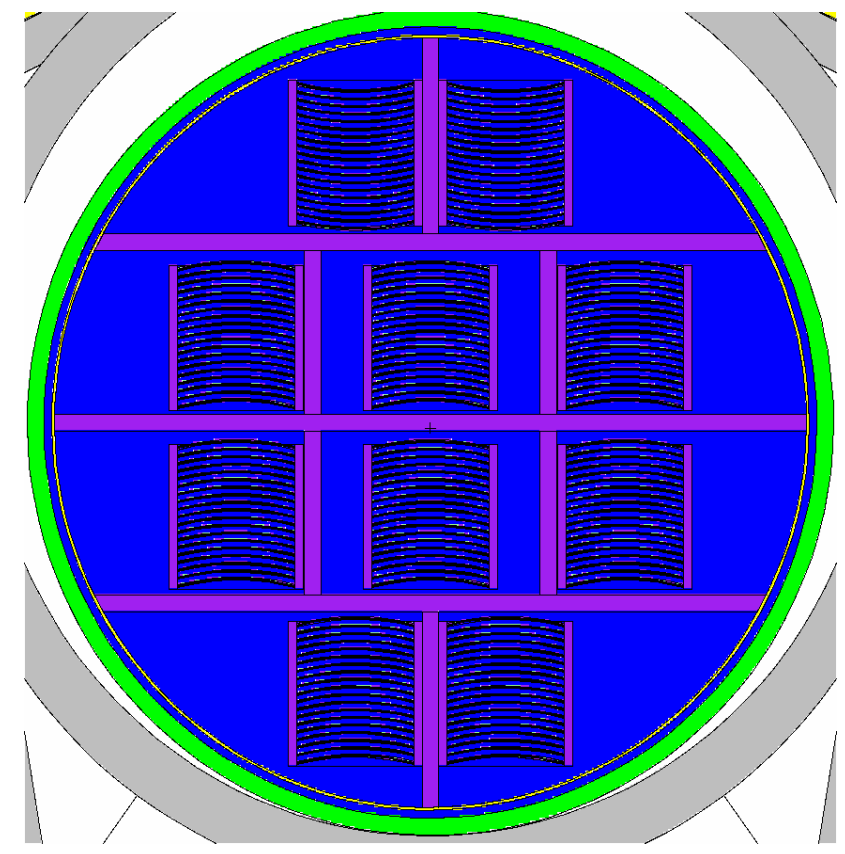

Figure 7.2-3. ORR fuel assemblies in a Type 1a basket. 
NATIONAL SPENT NUCLEAR FUEL PROGRAM ENGINEERING DESIGN FILE

EDF-NSNF-068

Revision 0

Page 34 of 84

Title: Criticality Analysis for Proposed Maximum Fuel Loading in a Standardized SNF Canister with Type 1a Baskets

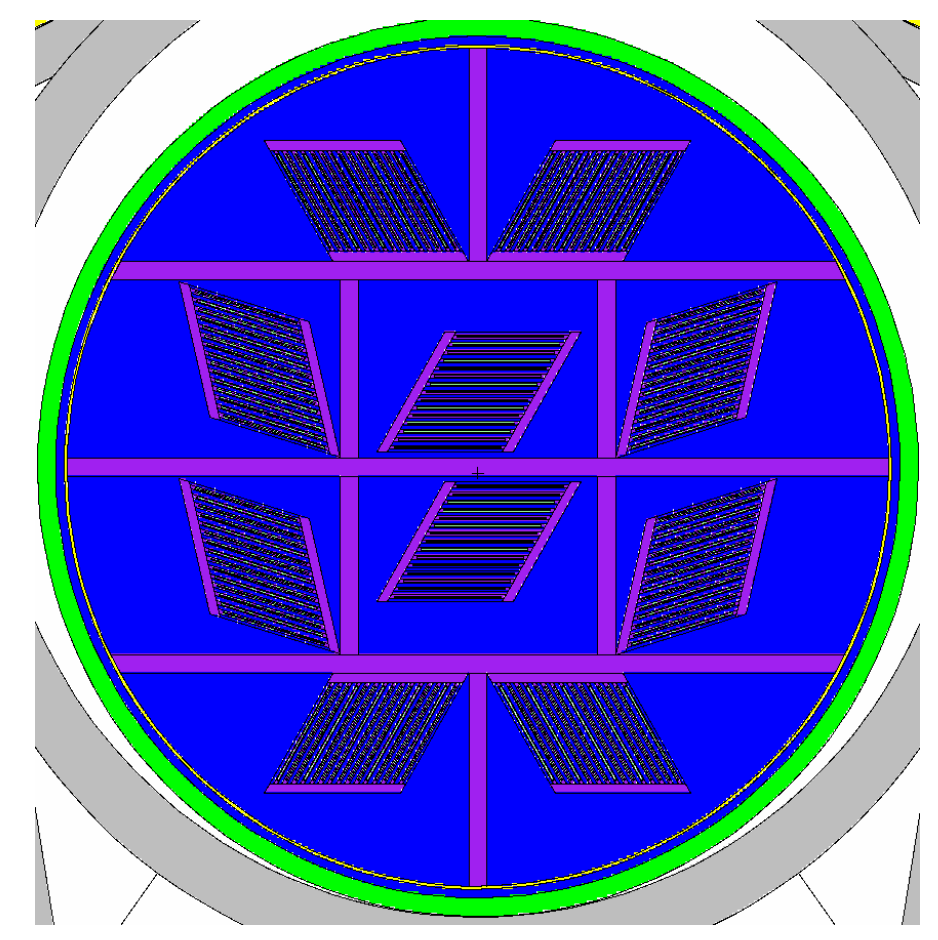

Figure 7.2-4. MIT fuel assemblies in a Type 1a basket. 

1a Baskets

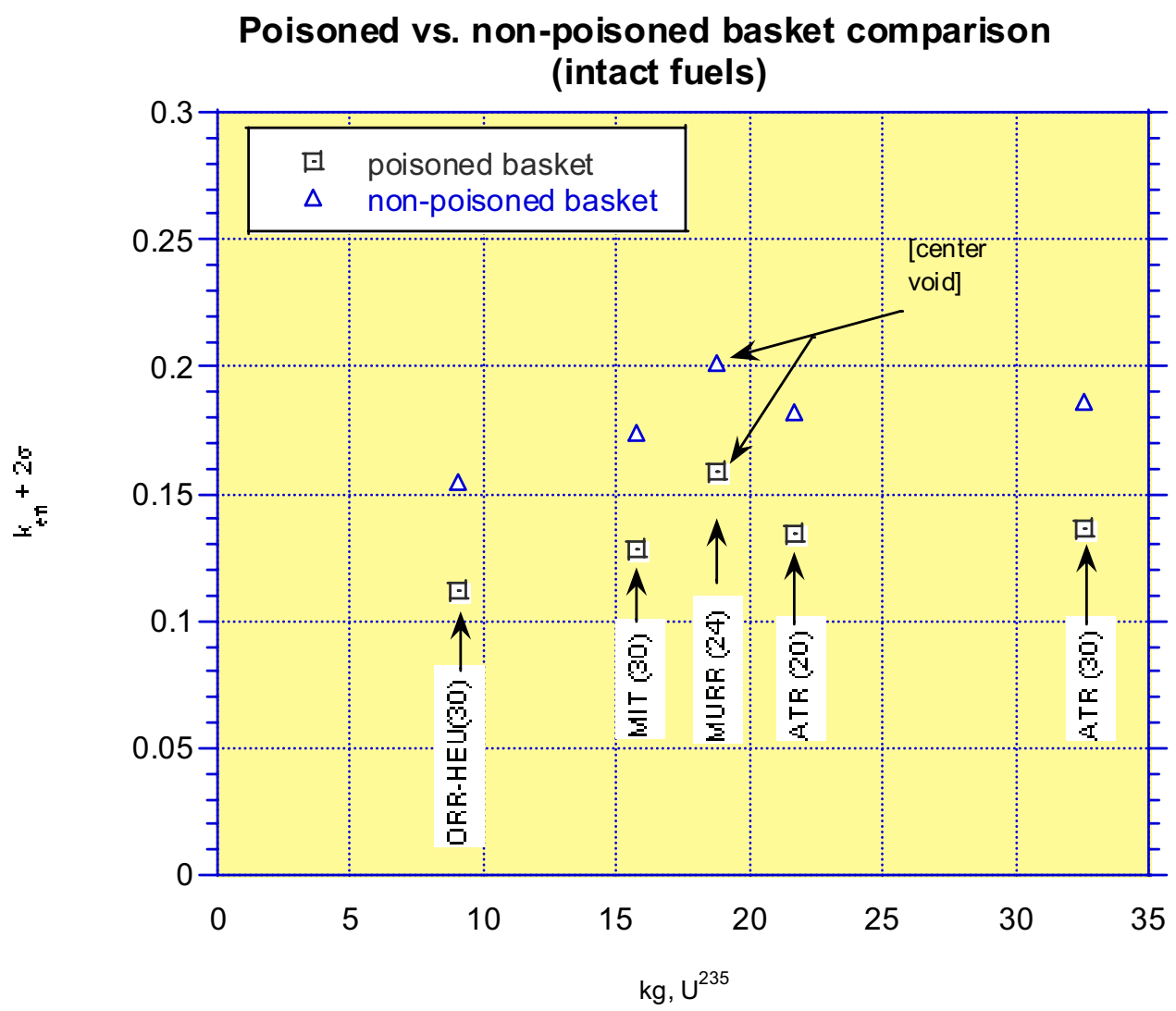

Figure 7.2-5. Gd effect on system reactivity for intact internals in a single, water reflected canister with and without poisoning.

Any baseline comparison case warrants an understanding of what the concentration of gadolinium (Gd) in the basket plate plays in meeting criticality safety. At issue is the credit allowed for any installed poisons. The Gd concentration in the basket plate material (UNS N06464; see Table 6.2-4) is installed to meet issues relative to total degradation of the fissile material inside a breached waste package within the post-closure repository environment. The presence of Gd is inconsequential to assuring criticality safety in a leak-tight canister with Type la basket and non-degraded fuels. No credit is being sought for the presence of $\mathrm{Gd}$ in the basket plates for any single canister configuration prior to the post-closure repository. Its presence is included in the model, because it is integral to any sealed canister utilizing a Type 1a basket configuration destined for repository disposal.

For comparison purposes, it is important to demonstrate the margin of safety for a single canister that could potentially be loaded underwater. Such a condition (both filled and reflected with water) is not likely to occur because of the operational difficulties associated with drying and sealing such a configuration. The calculated reactivities shown in Table 7.2-2 and Figure 7.2-6 portray that the proposed canister loadings can be enveloped with the ATR analyses (as fissile loads per canister decrease, so do the calculated reactivities). The comparative cases between the ATR (20) and ATR (30) loads demonstrate 
Revision 0

Page 36 of 84

Title: Criticality Analysis for Proposed Maximum Fuel Loading in a Standardized SNF Canister with Type 1a Baskets

the "infinite cylinder" principal, where, after a certain length and given the same linear fissile distribution, the calculated reactivity remains relatively constant.

Table 7.2-2. Results of intact fuels in a fully-flooded canister.

\begin{tabular}{lll}
\multicolumn{1}{c}{ Fuel Type } & Code Case & $\mathrm{k}_{\mathrm{eff}}+2 \sigma$ \\
\hline ATR $(20)$ & d1cnba.o & 0.6805 \\
ATR $(30)^{*}$ & d1cnbb+L.o & 0.6810 \\
MURR (24) & m1a24c.o & 0.6397 \\
MIT (30) & mit1d.o & 0.6135 \\
ORR-MEU (30) & olbleu.o & 0.6439 \\
\hline
\end{tabular}

* in 15 -ft long canister; all others in $10-\mathrm{ft}$ canisters

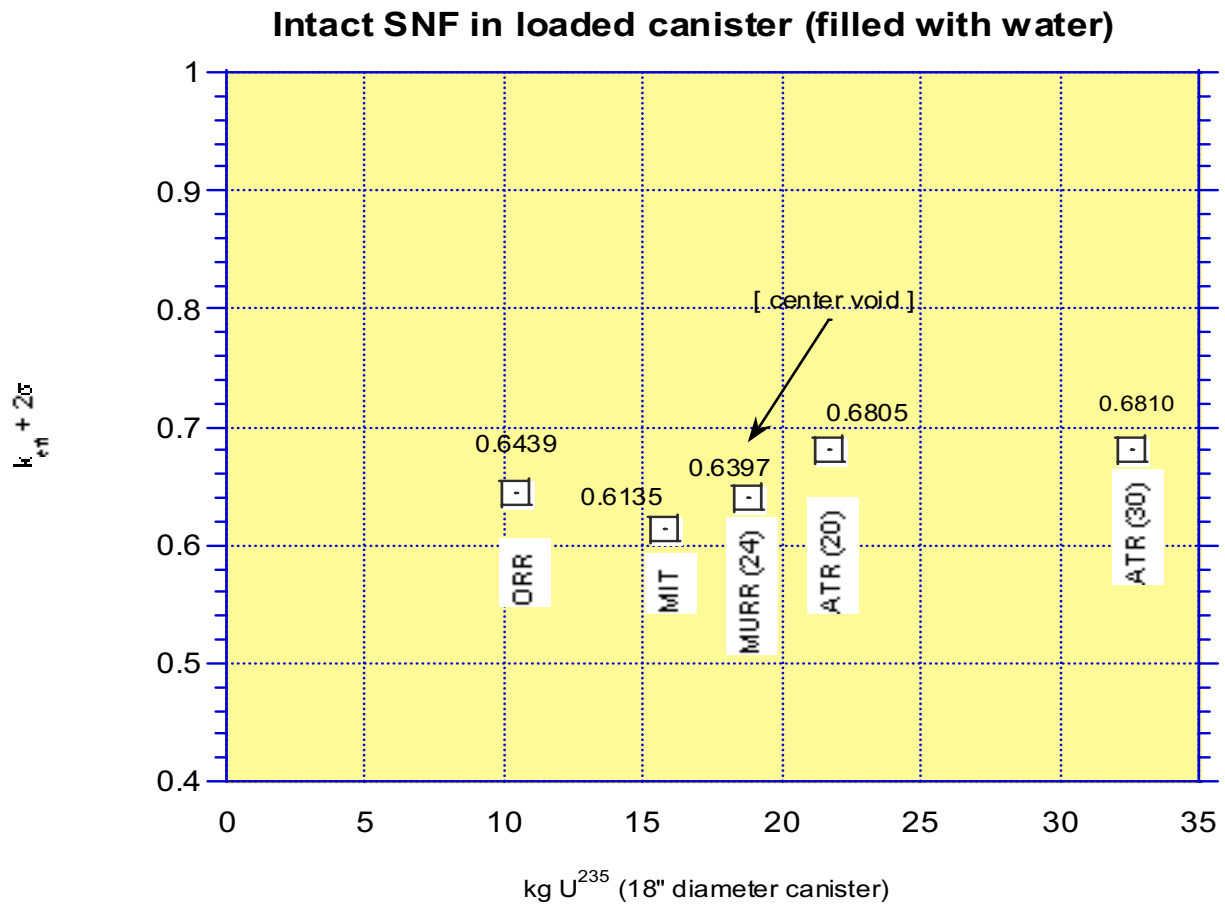

Figure 7.2-6. Calculated reactivities for intact SNF loaded in a fully-flooded canister. 
NATIONAL SPENT NUCLEAR FUEL PROGRAM ENGINEERING DESIGN FILE

EDF-NSNF-068

Revision 0

Page 37 of 84

Title: Criticality Analysis for Proposed Maximum Fuel Loading in a Standardized SNF Canister with Type 1a Baskets

\subsection{Degraded Configurations}

Various forms of both fuel and basket degradation might occur depending on the particular accident scenario. The variables in terms of degree of degradation (partial versus total collapse) and redistribution of canister internals (both fuel and basket) are too numerous to model in any practical manner for the most credible condition. Rather, the models selected focus on the most reactive configurations, and demonstrate with supplemental models how those most reactive cases satisfy that contention. This places some reliance on the use of non-mechanistic configurations to demonstrate maximum reactivities.

In general, highly-enriched fissile material in dry systems needs to attain the highest (most concentrated) fissile atom-density possible for maximum reactivity. Conversely, those same systems become more reactive in moderated conditions as they become more homogenous at an optimum $\mathrm{H} / \mathrm{X}$ ratio and then less reactive as the fissile concentration becomes more dilute. The baseline cases addressed in these degraded case models demonstrate both these contentions.

Degraded mode calculations consider both horizontal and vertical orientation of the canisters, for a single canister as well as a multi-canister arrays inside a hypothetical transport cask. Difficulties arise when trying to apportion and fixate the location of potentially reconfigured fissile material after any drop accident. Hence, degraded scenarios for these analyses conservatively assumed complete separation of the $\mathrm{UAl}_{\mathrm{x}} / \mathrm{Al}$ fissile matrix from any of the cladding and assembly end fittings. Thereafter, the fuel matrix material is distributed within the basket compartments anywhere from a full-density matrix layer to uniform (homogeneous) distribution with a calculated void fraction.

Specialized cases evaluated "what if" scenarios with axial reconfiguration of the fissile mass at the bottom of a vertically oriented canister and away from any of the poisoned basket material; the basket material becomes a reflecting surface at this point. For the worst case (non-mechanistic) scenario, all the fissile mass in a canister, i.e. from all the assemblies in all the baskets, is reconfigured at the fissile matrix production density either as a sphere or a cylindrical shape limited to the internal diameter of the canister. The more reactive of these two configurations was then used as the basis for analyzing the nine-pack canister array inside the hypothetical transport cask.

Scenarios for fuel degradation in transportation are confined to 'dry' reconfiguration as a result of some transportation accident. For 'dry' fissile systems, greater compactness of the fissile material generally promotes greater system reactivity. The following degradation scenarios portray what are progressively more reactive dry configurations. For fissile materials separated from the cladding, the cladding 'disappears' from the basket compartment as the most conservative approach. Any inclusion would beg the question as to what orientation or position should be assumed, e.g. submerged in the matrix debris or floating on top.

\subsubsection{Fuel Debris Separated and Horizontally Reconfigured in Basket Compartments}

With horizontal orientation of a canister, either after a drop or during reorientation after a drop, analyses evaluated reactivity with the fissile matrix material separated from between the clad plates of the ATR fuel and then reconsolidated on the side wall of each basket compartment. A void fraction of varying percentages was then assigned to the fuel rubble to determine the effect on calculated reactivity. 
EDF-NSNF-068

Revision 0

Page 38 of 84

Title: Criticality Analysis for Proposed Maximum Fuel Loading in a Standardized SNF Canister with Type 1a Baskets

Figure 7.3.1-1 depicts the configuration analyzed. All compartments were modeled with similar fuel rubblization, although the outer perimeter compartments result in slightly varying heights because of the canister radius influence on compartment area cross section.

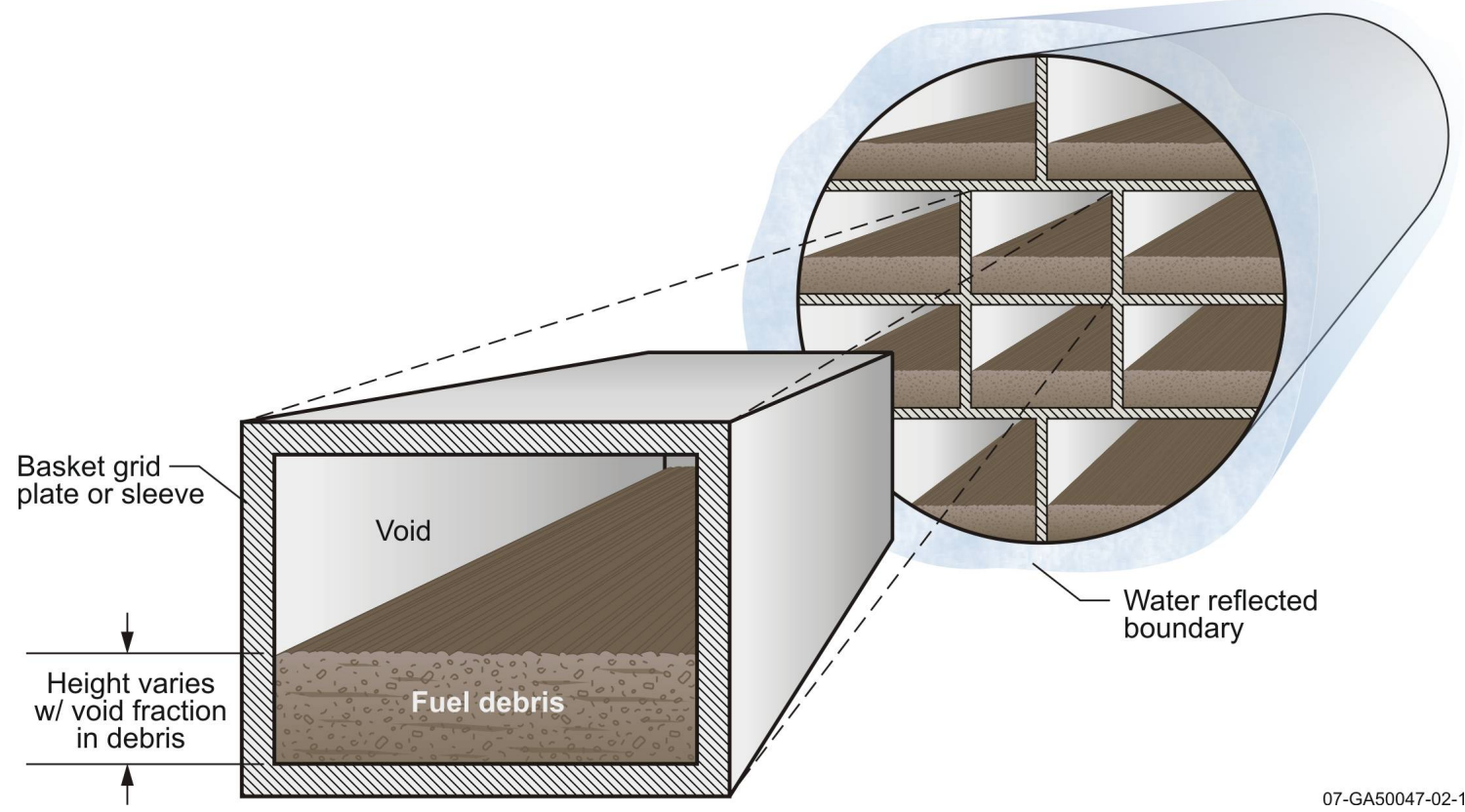

Figure 7.3.1-1 Cross section of canister with fuel debris separated and horizontally reconfigured in a Type 1a basket compartment

The first of the degraded cases examined rubblized fuel, with the fuel matrix material separating from between the aluminum cladding and depositing as a layer on the floor of each basket compartment in a horizontally oriented canister; see Figure 7.3.1-1. Table 7.3.1-1 itemizes the results of the criticality calculation for this configuration; Figure 7.3.1-2 depicts the results listed in Table 7.3.1-1. This analysis was done with a nominal $11 \mathrm{vol} \%$ water assumed trapped in the interstitial voids within the ATR fuel matrix; this equates to an $\mathrm{H} / \mathrm{X}$ ratio of approximately 2.1 ; analysis of other fuels used varying 'trapped water' content per Assumption 4.5. These analyses were done with four different fuel types for nonflooded cases within the SNF canister. The individual canisters were externally water reflected in all cases. 
Revision 0

Page 39 of 84

Title: Criticality Analysis for Proposed Maximum Fuel Loading in a Standardized SNF Canister with Type 1a Baskets

Table 7.3.1-1. Effect of fuel rubblization in a horizontally oriented basket compartments.

\section{Code Case}

(with $11 \mathrm{vol} \%$

\begin{tabular}{llc}
\multicolumn{1}{c}{ Fuel Type } & Water in SNF) & $\mathrm{k}_{\text {eff }}+2 \sigma$ \\
\hline ATR (20) & homa_0-w.o & 0.0855 \\
ATR (30)* & homa30-w.o & 0.0894 \\
MURR (24) & homa24c-w.o & 0.0885 \\
MIT (30)** & mthom_0-w.o & 0.0844 \\
ORR-HEU (30)*** & ohom_0-w.o & 0.0463 \\
\hline
\end{tabular}

* in 15-ft long canister; all others in 10-ft canisters

** $19.75 \mathrm{vol} \%$ water in fuel matrix

$* * * \sim 30 \mathrm{vol} \%$ water in fuel matrix

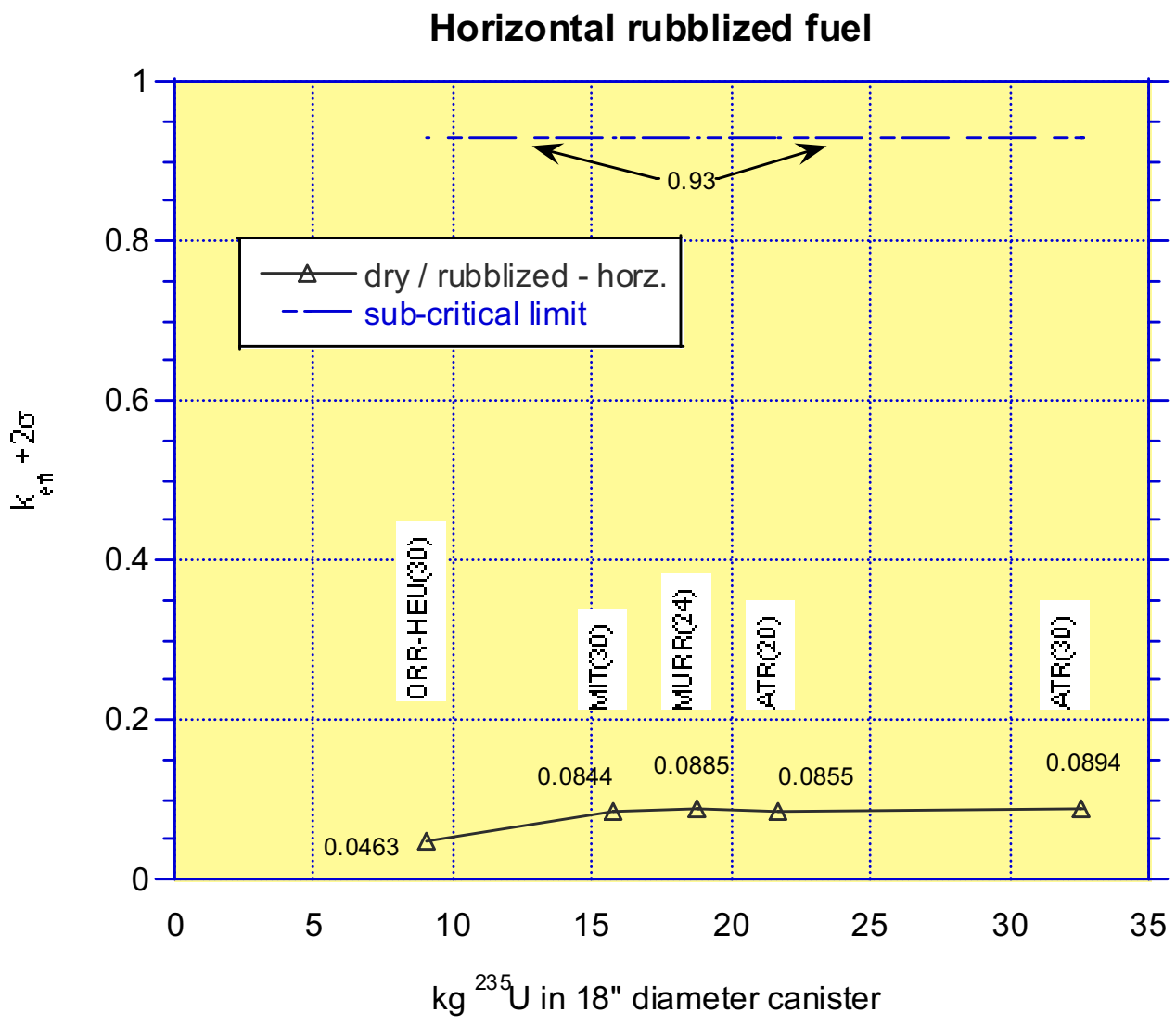

Figure 7.3.1-2. Rubblized fuel in a horizontal canister. 
EDF-NSNF-068

Revision 0

Page 40 of 84

Title: Criticality Analysis for Proposed Maximum Fuel Loading in a Standardized SNF Canister with Type 1a Baskets

\subsubsection{Fuel Debris Separated and Vertically Reconfigured in Basket Compartments}

While SNF canisters are typically stored, shipped and emplaced in the repository with horizontal orientation, there are brief periods when the SNF canister experiences vertical orientation during loading and unloading operations from transport casks and/or waste packages. Such orientation with rubblized fuel presents a different set of neutronic interactions from that of a horizontal canister. Note that the vertical debris model increases the calculated reactivity by a factor of two over that of the horizontal case for the same fuel.

The following reactivities were calculated as a result of assuming minimum void fraction in each of the fissile matrix debris piles formed in the bottom of each canister compartment; see Table 7.3.2-1. The analysis retained the appropriate water content in the fuel matrix material (see Assumption 4.5). Whether for ATR (20) two-stack in a 10-ft canister or ATR (30) three-stack arrangement inside a 15-ft canister, the infinite cylinder length principle, i.e. reactivity of fissile content per unit length remains constant beyond a given length, is demonstrated with Figure 7.3.2-1.

Table 7.3.2-1. Reactivities for degraded fuel in a vertically oriented canister.

Code Case

(w/ 11 vol\% water

\begin{tabular}{lcc}
\multicolumn{1}{c}{ Fuel Type } & in SNF) & $\mathrm{k}_{\mathrm{eff}}+2 \sigma$ \\
\hline ATR (20) & homaV_0-w.o & 0.1974 \\
ATR (30)* & homaV30_0-w.o & 0.1970 \\
MURR (24) ${ }^{(\mathrm{a})}$ & homV24_0-w.o & 0.1412 \\
MIT (30)** & mthomV_0-w.o & 0.1361 \\
ORR-HEU (30)*** & ohomV_0-w.o & 0.0740 \\
$*$ *15-ft long canister; others packaged in 10-ft canisters & \\
$* * 19.75$ vol\% water in fuel matrix & \\
$* * * \sim 30$ vol\% water in fuel matrix &
\end{tabular}

(a) Six boundary FHUs removed from 30 FHUs; constitutes a misload.

Note that the cases for the ATR(20) [case: homaV_0-w.o] and MURR(24) [case: homV24_0-w.o] become the starting points for each of the two following void fraction calculations for those respective fuels. 
Page 41 of 84

Title: Criticality Analysis for Proposed Maximum Fuel Loading in a Standardized SNF Canister with Type 1a Baskets

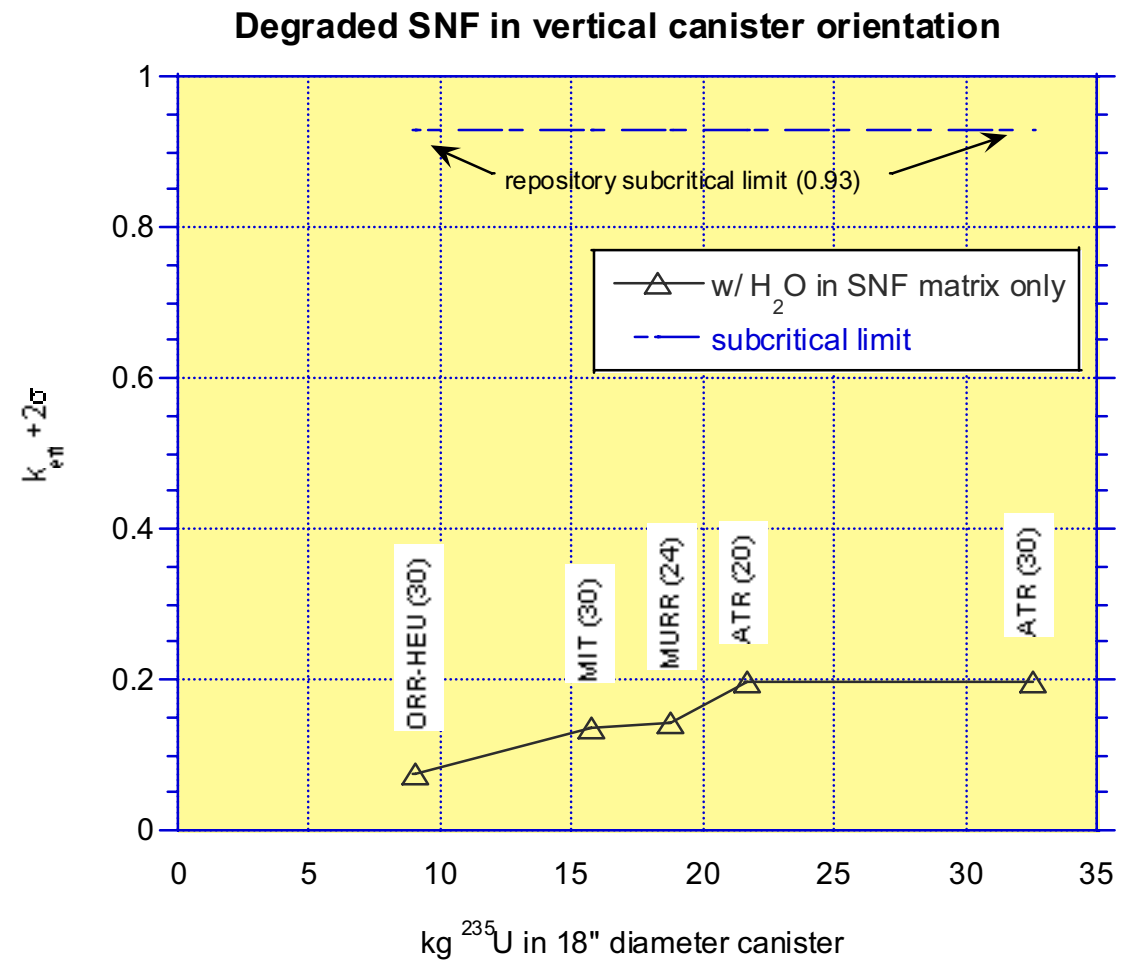

Figure 7.3.2-1. Reactivities of degraded fuel in vertically oriented 18 " canister.

Assigning a void fraction of varying percentages to the fuel rubble determined the effect on calculated reactivity. Figure 7.3.2-2 depicts a side view of three stacked, vertically oriented basket compartments. All compartments with fuel were modeled with similar fuel rubblization, although the outer perimeter compartments result in slightly varying debris heights because of the canister radius influence on basket compartment area cross section.

The results shown in Table 7.3.2-2 represent the rubblization of the ATR fuel matrix material away from any cladding or side plates of the assemblies. All of fissile material from each fuel assembly is retained within its respective basket compartment in a vertical orientation. The fissile matrix also retains its $11 \mathrm{vol} \%$ water. The tabular results and Figure 7.3.2-3 demonstrate that as fissile atom densities decrease in a dry system with a fixed geometry, so too do the calculated reactivities. 
NATIONAL SPENT NUCLEAR FUEL PROGRAM ENGINEERING DESIGN FILE

EDF-NSNF-068

Revision 0

Page 42 of 84

Title: Criticality Analysis for Proposed Maximum Fuel Loading in a Standardized SNF Canister with Type 1a Baskets

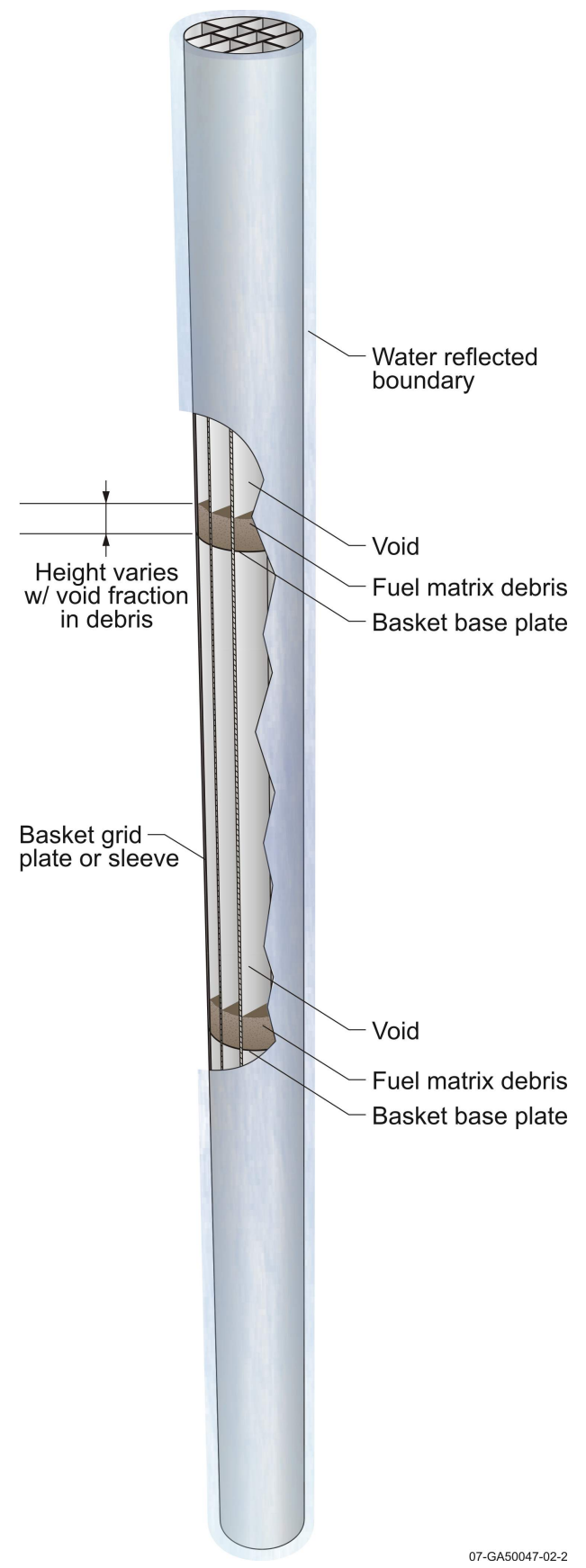

Figure 7.3.2-2 Side view cross-section of two stacked, vertically oriented Type 1a basket compartments. 
Revision 0

Page 43 of 84

Title: Criticality Analysis for Proposed Maximum Fuel Loading in a Standardized SNF Canister with Type 1a Baskets

Table 7.3.2-2. Results for degraded ATR (20) fuel inside vertically oriented basket compartments.

ATR (20)

\begin{tabular}{lcc} 
& Vertical Code Case & $\mathrm{k}_{\text {eff }}+2 \sigma$ \\
\hline $\mathrm{vf}=0$ & homaV_0-w.o & 0.1974 \\
$\mathrm{vf}=0.2$ & homaV_20-w.o & 0.1742 \\
$\mathrm{vf}=0.4$ & homaV_40-w.o & 0.1473 \\
$\mathrm{vf}=0.5$ & homaV_50-w.o & 0.1320 \\
$\mathrm{vf}=0.6$ & homaV_60-w.o & 0.1152 \\
$\mathrm{vf}=0.75$ & homaV_75-w.o & 0.0882 \\
$\mathrm{vf}=0.817$ (full) & homaV_fl-w.o & 0.0811 \\
\hline${ }_{\mathrm{vf}}=$ void fraction (in any debris formation) & & \\
\hline
\end{tabular}

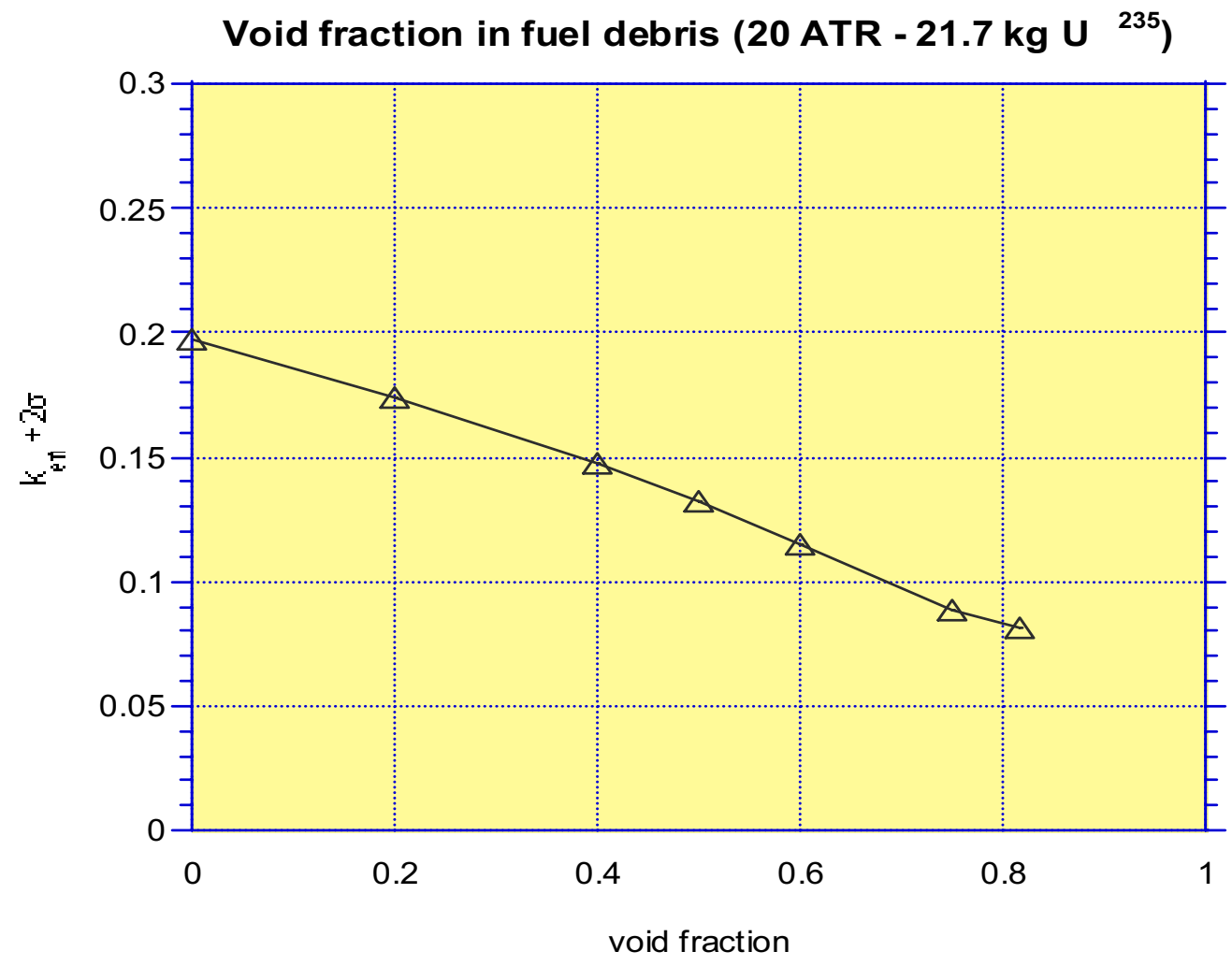

Figure 7.3.2-3. Reactivity as a function of void fraction in ATR fuel. 
Revision 0

Page 44 of 84

Title: Criticality Analysis for Proposed Maximum Fuel Loading in a Standardized SNF Canister with Type 1a Baskets

A similar calculation with the MURR (24) fuel packaging shows the same behavior as the ATR (20) fuel packaging, only with lower reactivities due to lower total fissile mass (18.79 vs. $\left.21.7 \mathrm{~kg}{ }^{235} \mathrm{U}\right)$. Table 7.3.2-3 and Figure 7.3.2-4 depict this trend.

Table 7.3.2-3. Results for degraded MURR (24) fuel inside vertically oriented canister compartments.

\begin{tabular}{lll} 
& \multicolumn{3}{c}{$\operatorname{MURR}(24)^{(\mathrm{a})}$} & \\
& Vertical Code Case & $\mathrm{k}_{\mathrm{eff}}+2 \sigma$ \\
\hline $\mathrm{vf}=0$ & homV24_0-w.o & 0.1412 \\
$\mathrm{vf}=0.2$ & homV24_20-w.o & 0.1300 \\
$\mathrm{vf}=0.4$ & homV24_40-w.o & 0.1159 \\
vf=0.6 & homV24_60-w.o & 0.0991 \\
vf=0.7 & homV24_75-w.o & 0.0900 \\
vf=0.78 (full) & homV24_fll-w.o & 0.0866 \\
\hline
\end{tabular}

$* \mathrm{vf}=$ void fraction (in any debris formation)

(a) Six boundary FHUs removed from 30 FHUs; constitutes a misload. The 'misload' was selected for this tabular presentation because it yielded a higher reactivity than the proposed center void configuration.

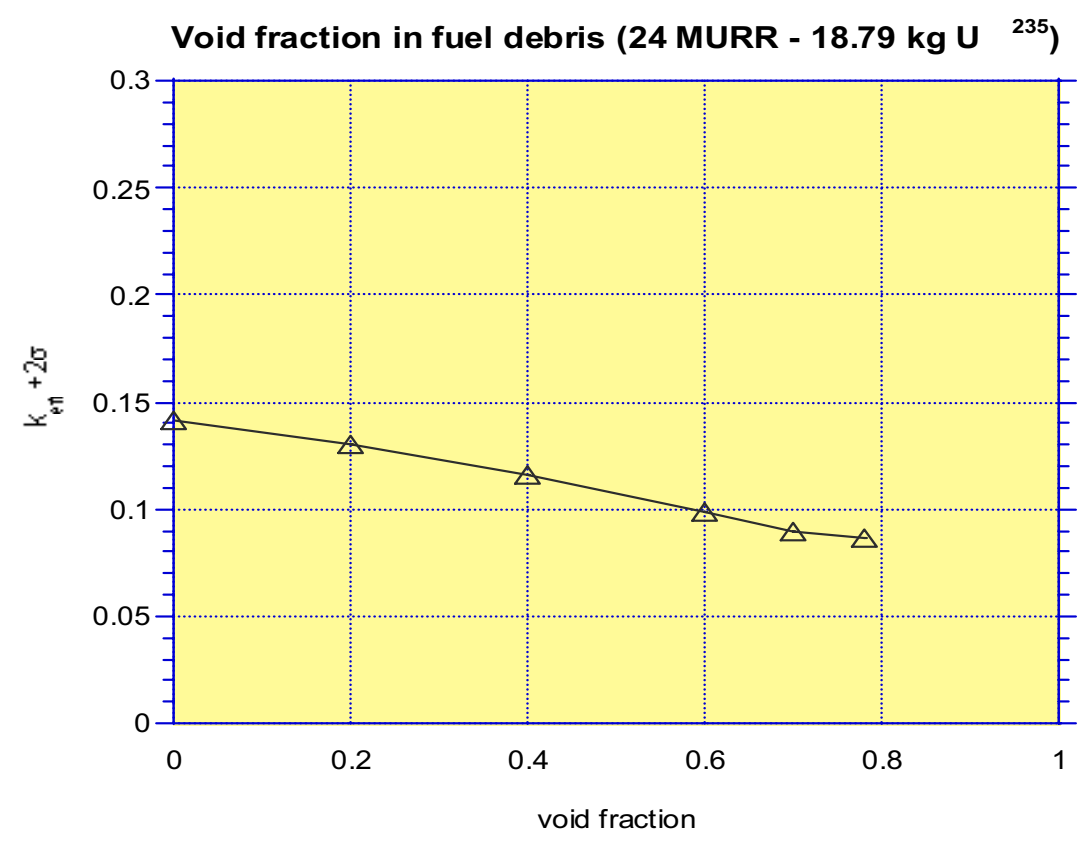

Figure 7.3.2-4. Reactivity as a function of void fraction in MURR fuel. 
EDF-NSNF-068

Revision 0

Page 45 of 84

Title: Criticality Analysis for Proposed Maximum Fuel Loading in a Standardized SNF Canister with Type 1a Baskets

\subsubsection{Basket Grid Plates Fail and Reconfigure Horizontally}

The sensitivity of plate spacing was modeled by moving the horizontal plates closer together, but limited by the geometry of the fuel in the compartment. Figure 7.3.3-1a shows a conventional spacing of fuel assemblies within adjacent basket compartments. Figure 7.3.3-1b 'drops' the top horizontal plate such that it rests on the fuel assembly below. All fuel elements in each basket compartment were placed closer together (vertically) as a result of this reconfiguration. The drawings are not to scale; rather they depict relative positioning of basket plates and fuel shapes. The degraded plate/degraded fuel condition in the horizontal canister orientation was not analyzed because the distribution of the fuel debris over the length of the canister provides such a high surface to volume ratio for neutron leakage. A more reactive configuration than horizontal debris formation would be bounded by the vertical (or axial) configuration analyzed in Section 7.3.4.

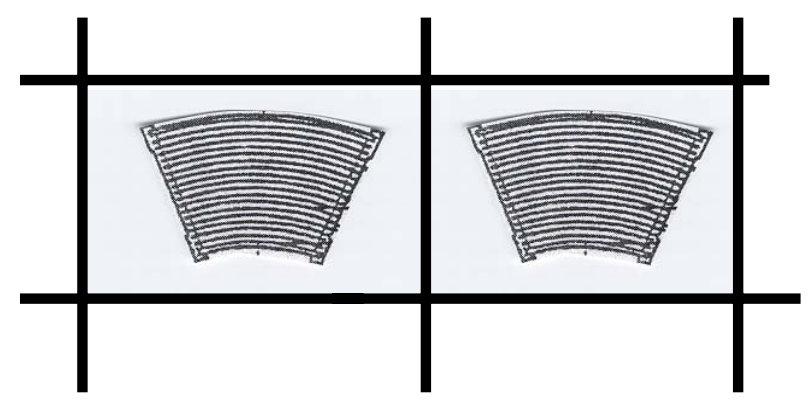

Figure 7.3.3-1a Conventional ATR spacing within Type 1a basket

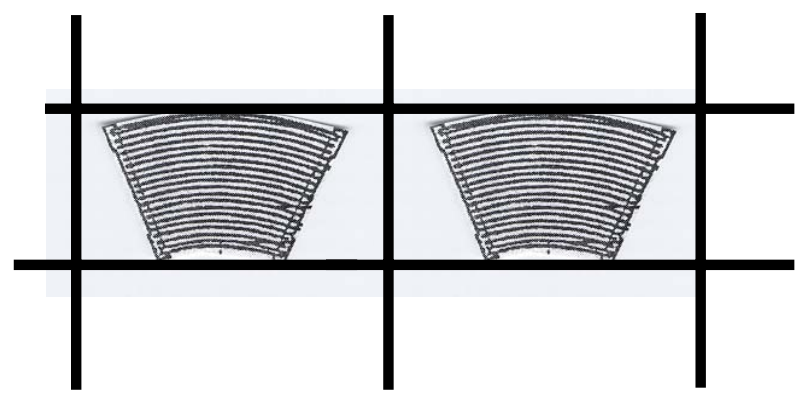

Figure 7.3.3-1b Collapsed basket plates constrained by fuel shape

To determine sensitivity to basket plate displacement, the analysis posed a canister side-drop where the plates would somehow move closer together until they were touching the ATR assemblies. All other parameters were retained ( $11 \mathrm{vol} \%$ water in ATR fuel matrix, water reflection of the canister, and no fuel or canister deformation). The results shown in Table 7.2-5 show a slight increase in reactivity $\left(\mathrm{k}_{\mathrm{eff}}=\right.$ 0.1407 ) versus the undamaged configuration for ATR (30) fuels in an intact basket of $\mathrm{k}_{\mathrm{eff}}=0.1367$ (see Table 7.1-1). 
NATIONAL SPENT NUCLEAR FUEL PROGRAM ENGINEERING DESIGN FILE

EDF-NSNF-068

Revision 0

Page 46 of 84

Title: Criticality Analysis for Proposed Maximum Fuel Loading in a Standardized SNF Canister with Type 1a Baskets

Table 7.3.3-1. Result for ATR (30) fuel side drop.

\begin{tabular}{ccc} 
Fuel Type & Code Case & $\mathrm{k}_{\text {eff }}+2 \sigma$ \\
\hline ATR (30) & atr30-side-dropr.o & 0.1384 \\
\hline
\end{tabular}

\subsubsection{Basket Base Plates Fail and Fuel Debris Reconfigures Vertically}

More reactive debris configuration than the horizontal orientation, this model analyzed the artificial positioning of the basket base plates at the bottom of the canister, and with the fuel matrix debris from all three baskets collected and consolidated as a single layer in the bottom of a vertically oriented SNF canister. This constitutes the axial reconfiguration scenario. This is strictly a non-mechanistic reconfiguration, as there are no accident scenarios that might allow the base plates to separate from their respective baskets while maintaining relative positioning of the basket side plates. This simplified model is depicted in Figure 7.3.4-1. The analysis modeled each of the compartments with the fuel matrix debris material from the above compartments in a three stack basket arrangement.

Although limited in nature because of the small amount of time any canister spends in a vertical orientation, axial reconfiguration of the fuel has always posed the greatest concern in terms of increased reactivity due to accident scenarios. Whether rubblization of the canister internals occurs with a vertical drop scenario, or a side drop and a vertical orientation upon recovery efforts, fissile material reconfiguration needed to be addressed for SNF canisters in transport. An axial reconfiguration scenario examined rubblization of the fuel in a three-stack ATR (30), with the fuel matrix material separating from between the aluminum cladding and collecting inside the bottom 10 basket compartments. Once again with the $11 \mathrm{vol} \%$ water in the fuel matrix and external water reflection, the most reactive condition is the consolidated debris with minimal void fraction. These results are shown in Table 7.3.4-1 and Figure 7.3.4-2.

Table 7.3.4-1. Result for ATR (30) fuel end-drop.

\begin{tabular}{llc}
\hline & ATR End Drop & $\mathrm{k}_{\text {eff }}+2 \sigma$ \\
\hline $\mathrm{vf}=0.0$ & homaE_0.o & 0.4097 \\
$\mathrm{vf}=0.20$ & homaE_20.o & 0.3667 \\
$\mathrm{vf}=0.50$ & homaE_50.o & 0.2868 \\
\hline
\end{tabular}


NATIONAL SPENT NUCLEAR FUEL PROGRAM ENGINEERING DESIGN FILE

EDF-NSNF-068

Revision 0

Page 47 of 84

Title: Criticality Analysis for Proposed Maximum Fuel Loading in a Standardized SNF Canister with Type 1a Baskets

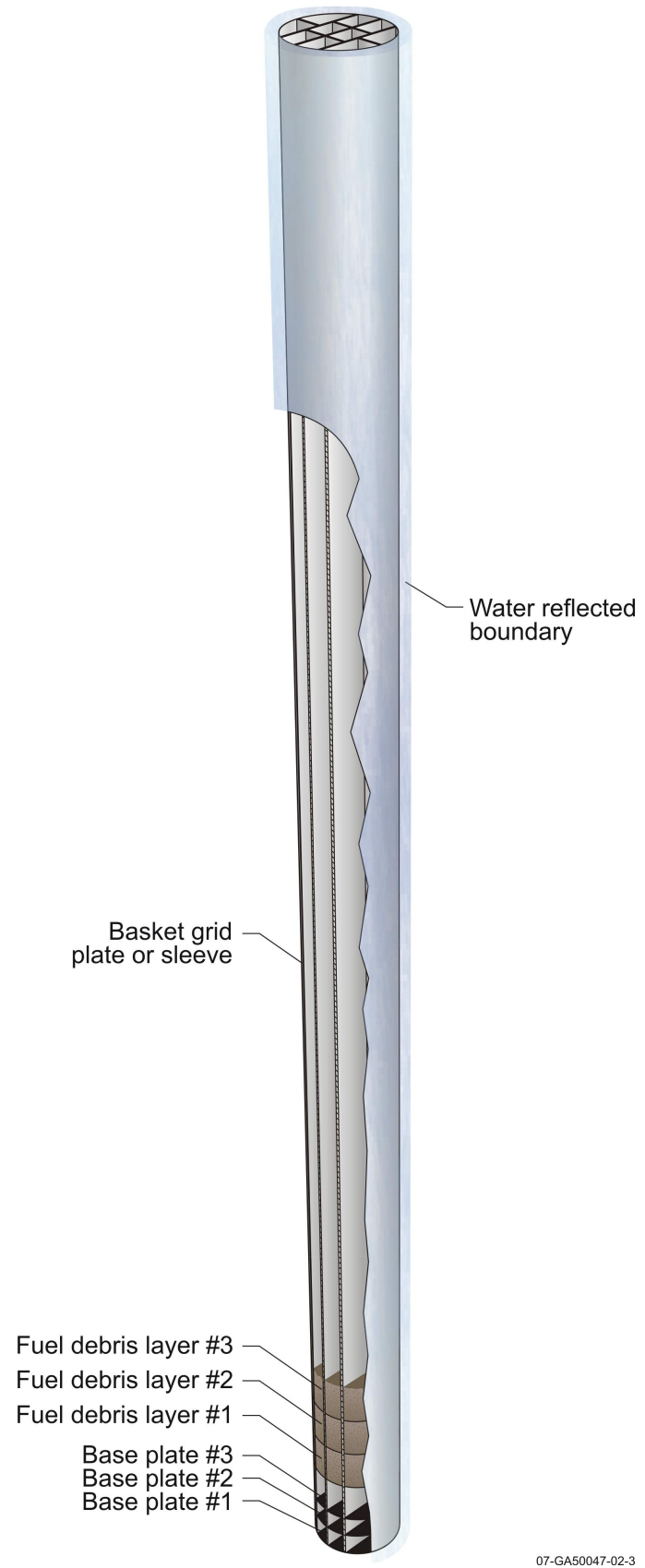

Figure 7.3.4-1 Collapsed basket plates and fuel debris constrained in basket compartments 
Title: Criticality Analysis for Proposed Maximum Fuel Loading in a Standardized SNF Canister with Type 1a Baskets

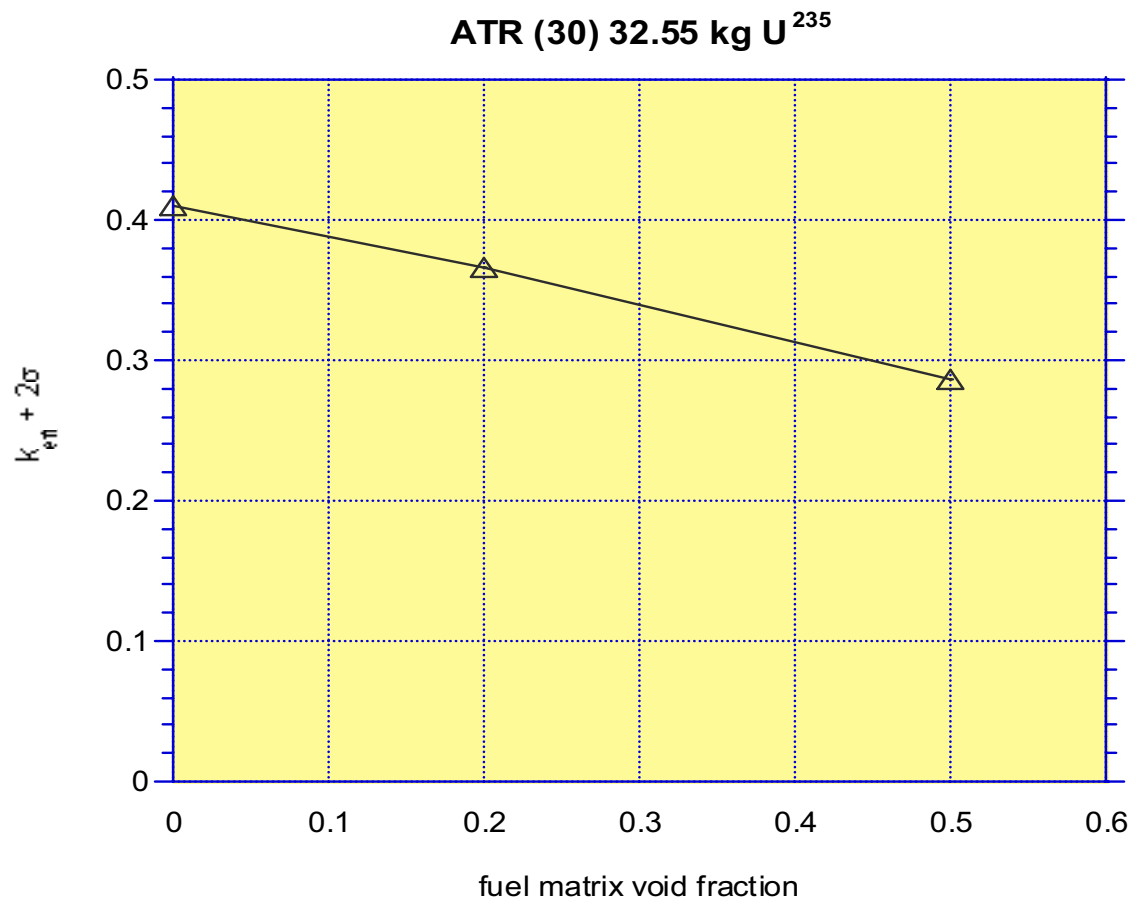

Figure 7.3.4-2. Reactivity in a vertically oriented canister with fuel degraded and reconfigured in one set of basket compartments.

\subsubsection{Fuel non-mechanistically separates and assembles in a sphere below basket and cladding material}

Figure 7.3.5-1 represents what was expected to be the most reactive configuration based on knowledge of the neutronics typically associated with bare spherical assembly of fissile material. A sphere represents the most optimal shaped and smallest surface/volume ratio for neutron economy.

The most extreme degradation case examines a non-mechanistic configuration. This involves axial reconfiguration of the fuel matrix material, with the mass of fuel matrix material in a single canister forming into a spherical geometry below and away from all poisoned basket plate material. The spherical shape is typically considered to be the most reactive geometry for any dry fissile system. The results for this scenario for both the ATR (30) and MURR (24) are provided in Table 7.3.5-1. 
EDF-NSNF-068

Revision 0

Page 49 of 84

Title: Criticality Analysis for Proposed Maximum Fuel Loading in a Standardized SNF Canister with Type 1a Baskets

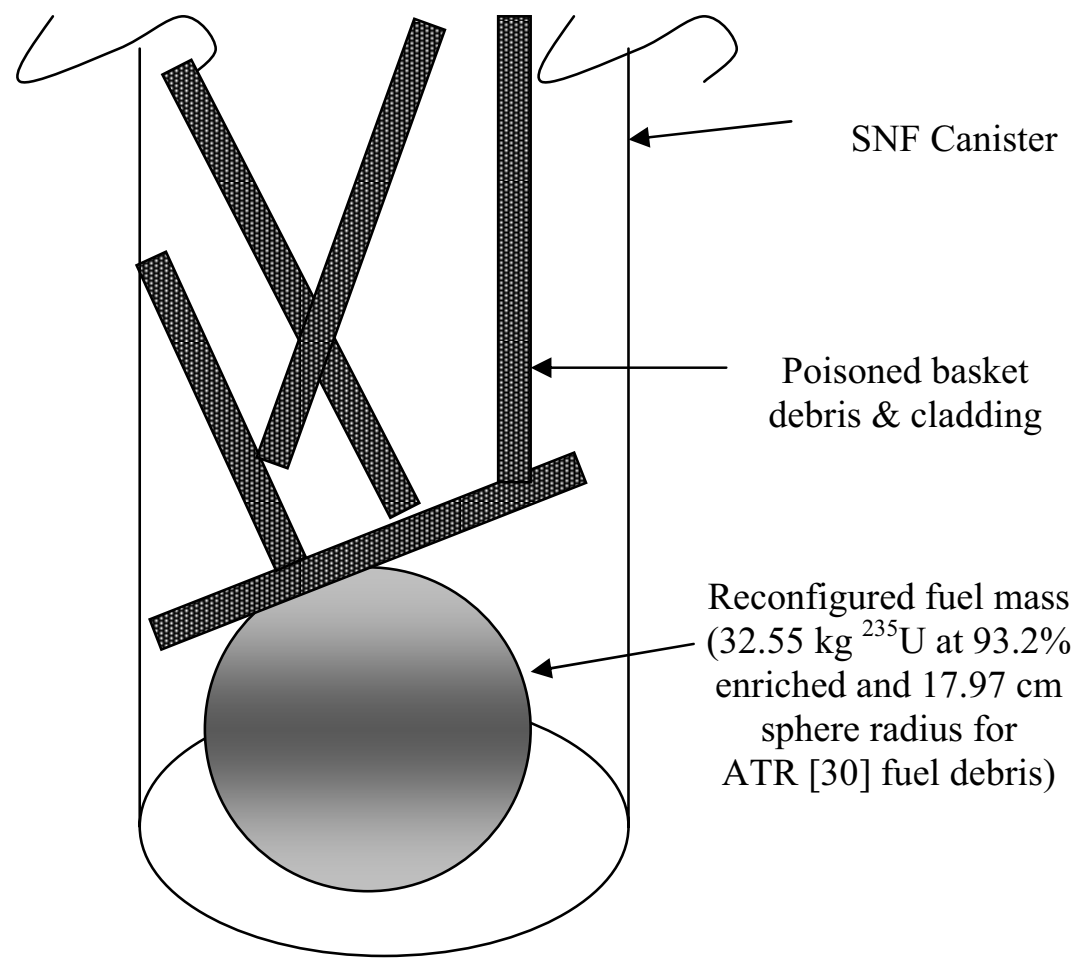

Figure 7.3.5-1. Spherical fuel debris without poison in sphere.

Table 7.3.5-1. Results of degraded spherical fuel matrix mass in SNF canister.

\begin{tabular}{lcc}
\multicolumn{1}{c}{ Fuel Type } & Code Case & $\mathrm{k}_{\text {eff }}+2 \sigma$ \\
\hline ATR (30) (sphere) & sph_0.o & 0.5479 \\
MURR (24) & sph-mu2410.o & 0.4160 \\
\hline
\end{tabular}

\subsubsection{Fuel non-mechanistically separates and assembles in a cylinder below basket and cladding material}

An adjunct calculation examined cylindrical fuel debris formation in the bottom of a vertically oriented SNF canister. The cylindrical shape was limited by the internal diameter of the SNF canister, and the base plates and basket debris constituted reflective boundaries. This cylindrical model better represents the artificial reassembly of fuel matrix debris in the bottom of the canister. This scenario is depicted in Figure 7.3.6-1. 
EDF-NSNF-068

Revision 0

Page 50 of 84

Title: Criticality Analysis for Proposed Maximum Fuel Loading in a Standardized SNF Canister with Type 1a Baskets

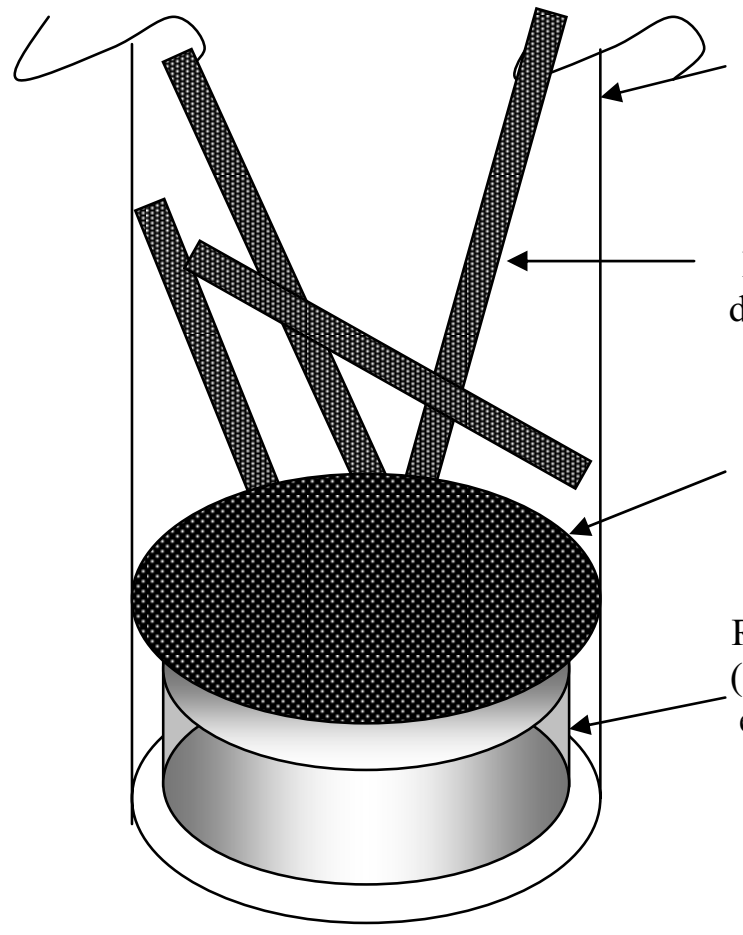

SNF
Canister

Poisoned basket

debris \& cladding

Three basket

base plates

Reconfigured fuel mass $\left(32.55 \mathrm{~kg}^{235} \mathrm{U}\right.$ at $93.2 \%$ enriched and $42.61 \mathrm{~cm}$

diameter cylinder/

$17.08 \mathrm{~cm}$ height for

ATR [30])

Figure 7.3.6-1. Cylindrical fuel debris without poison in cylinder.

The results shown in Table 7.3.6-1 for any of the aluminum plate fuels shows a slightly increased reactivity over that calculated for the spherical geometry in the preceding table. This increase is attributed to the reflective nature of the boundaries imposed by the canister wall, top and bottom reflection by the basket plates and bottom canister impact plate, respectively, and the external water reflection of the canister. This configuration of the ATR (30) canister was then used as the most reactive case for modeling in hypothetical transport cask analysis (see Section 7.4). No attempt was made to optimize the L/D ratio of the cylindrical shape at the bottom of the canister, since rubblizing the fuel to the extent necessary to migrate and reform the fuel debris in the bottom of the canister would fill all voids radially.

Table 7.3.6-1. Results of degraded cylindrical fuel matrix mass in SNF canister.

\begin{tabular}{llc}
\multicolumn{1}{c}{ Fuel Type } & Code Case & $\mathrm{k}_{\text {eff }}+2 \sigma$ \\
\hline ATR (30) & cyl_0+ca.o & 0.6249 \\
MURR (24) & cy_0-mu24.o & 0.4625 \\
MIT (30) & cy_0-mit.o & 0.5026 \\
ORR-MEU (30) & cy_0-orr.o & 0.5440 \\
\hline
\end{tabular}


EDF-NSNF-068

Revision 0

Page 51 of 84

Title: Criticality Analysis for Proposed Maximum Fuel Loading in a Standardized SNF Canister with Type 1a Baskets

The calculated reactivity for the MIT and ORR fuels is attributed to the size difference in the cylindrical geometry because of the different matrix (oxide versus silicide versus aluminide) and the increased water volume \% increase in the fuel matrix (see Assumption 4.5). The ATR (30) still represents the bounding case for maximum reactivity.

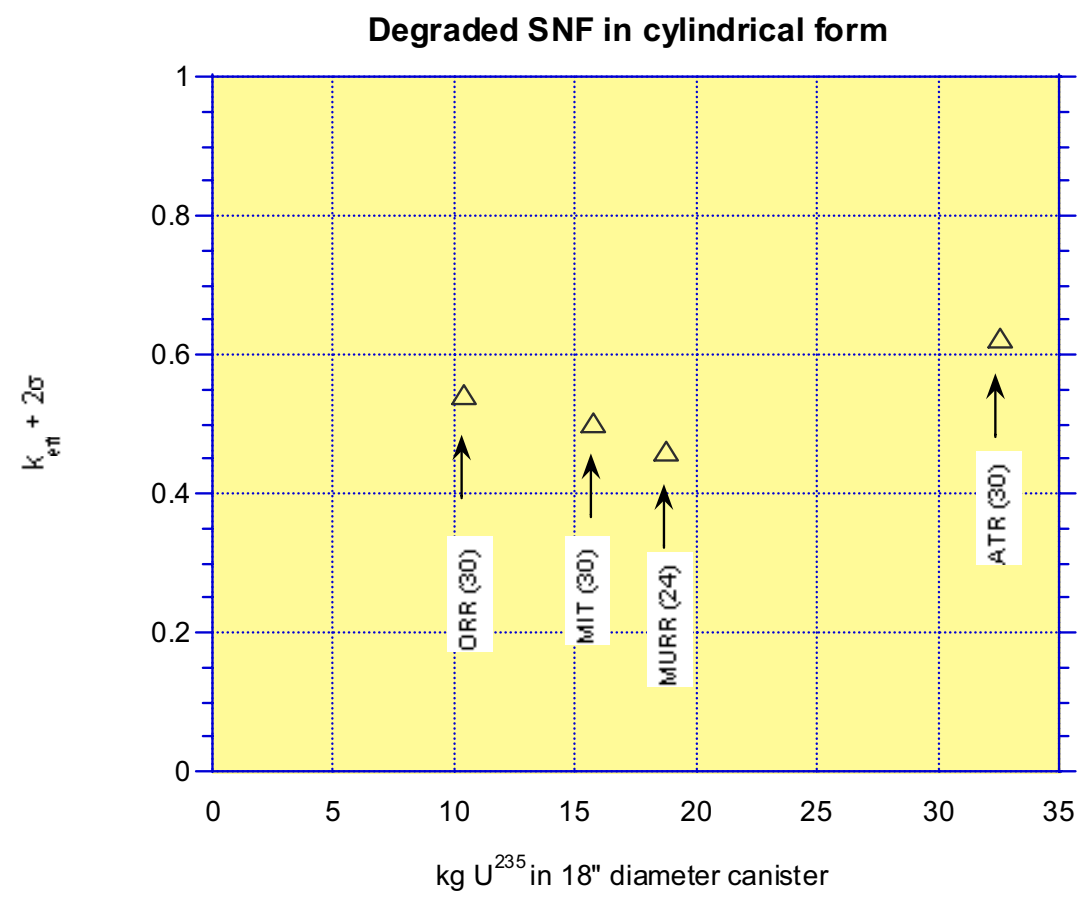

Figure 7.3.6-2. Degraded fuel accumulated in the bottom of a vertically oriented cask.

\subsubsection{Fuel Debris in a Flooded Canister}

As a confirmatory analysis for problems that might arise with breach and flooding of a loaded canister, the analyst examined non-mechanistically degraded ATR fuel assemblies still contained within their poisoned basket compartments, but with full flooding in the SNF canister. This model is a variant of Figure 7.3.2-2, only with water inserted into the void fraction within the fuel debris. The various water volume fractions (wvf) shown in the 4th column of Table 7.3.7-1 represent the differences in free volume within each of the three separate basket compartment volumes (created because of the way the basket compartment volumes are defined by the basket divider positions). Given the fully loaded 15' canister with ATR fuel, the typical subcritical limit of 0.95 could be exceeded, given maximal fuel rubblization and optimum moderation. 
Page 52 of 84

Title: Criticality Analysis for Proposed Maximum Fuel Loading in a Standardized SNF Canister with Type 1a Baskets

Table 7.3.7-1. Results of degraded and flooded ATR fuel matrix mass in SNF canister.

\begin{tabular}{|c|c|c|l|l|}
\hline $\mathrm{k}_{\text {eff }} \pm \sigma$ & $\mathrm{k}_{\text {eff }}+2 \sigma$ & $\begin{array}{c}\text { AENCF } \\
\mathrm{keV}\end{array}$ & \multicolumn{1}{|c|}{ Comment } & File Name \\
\hline $0.9508 \pm 0.0008$ & 0.9523 & 10.0 & $\begin{array}{l}\text { wvf=0.817, 0.792 and 0.775; fuel } \\
\text { compartments are completely full; 3 } \\
\text { baskets in a 15' SNF canister }\end{array}$ & homa_fl+L.o \\
\hline
\end{tabular}

\subsection{Hypothetical Cask Configurations}

While the future cask vendor will perform final criticality safety evaluations for the authorized cask configuration, it is of interest to know a priori the potential for being able to transport multiple SNF canisters while maintaining adequate margins of criticality safety. To this end, analyses were performed with a hypothetical transport cask/basket combination using both a nine-pack and seven-pack canister array.

Four cask configurations were evaluated. The first is based on a flooded cask with all of the canisters in their worst-case single canister reactivities ("basket base plates fail and reconfigure vertically" scenario). The next three are with the canisters in their "as-loaded" configuration but with three different scenarios relative to inleakage of water.

- canisters dry and the cask cavity flooded.

- cask and the canister cavities flooded.

- canisters flooded and the cask cavity dry. This case represents the differentially flooded scenario in which both cask and canisters were flooded, but in which the cask cavity drains at a more rapid rate than the canister cavities.

The 9-pack array was modeled as a centering pipe (20" XS pipe in 304L SS [0.500" wall thickness]) with eight canisters arrayed around the outside and separated by 0.500 " thick plates; see Figure 7.4-2a. The fissile matrix inside the SNF canisters incorporates the vol\% water appropriate to the fuel analyzed (see Assumption 4.5). Each case for the flooded cask configurations evaluated $0 \%, 10 \%$, and $100 \%$ flooding outside the canisters in the array (to model the potential breach of the transport cask).

A similar criticality analysis was completed with a 7-pack array; see Figure 7.4-2b. This configuration was selected because of the concerns related to apparent dimensional constraints found in a 9-pack array, and also because a triangular pitch is known to produce a more reactive configuration. The basket model used the same 0.5-in. compartment thickness for each of the SNF canisters. 
Revision 0

Page 53 of 84

Title: Criticality Analysis for Proposed Maximum Fuel Loading in a Standardized SNF Canister with Type 1a Baskets

All cases showed decreasing reactivities with both decreased fissile loads (as expected with decreased fissile atom densities) in their canisters, and with increased flooding inside the transport cask. These results are shown in Table 7.4-1 and Figure 7.4-1. Decreased reactivities with decreased fissile loads is an expected condition due to lower fissile masses, and the concurrent decrease in either fissile mass geometry of decreased fissile atom density as a function of the fissile matrix composition. Addition of water to the transport cask provides an effective neutronic isolation barrier. Thermalized neutrons are more subject to capture if reflected into the SNF canister with its Gd-poisoned basket, or ultimate capture or escape outside the canisters.

Table 7.4-1. Results of nine aluminum fueled canisters loaded in a cask.

\begin{tabular}{|c|c|c|c|}
\hline Fuel Type & $\begin{array}{c}\text { Water Volume } \\
\text { Fraction Outside } \\
\text { Canisters } \\
(\%)\end{array}$ & Code Case & $\mathrm{k}_{\mathrm{eff}}+2 \sigma$ \\
\hline \multirow{12}{*}{ ATR (30) } & 0 & m9cya 0.0 & 0.8656 \\
\hline & 1 & m9cya_1.o & 0.8666 \\
\hline & 2 & m9cya 2.0 & 0.8625 \\
\hline & 3 & m9cya 3.0 & 0.8617 \\
\hline & 4 & m9cya 4.0 & 0.8580 \\
\hline & 5 & m9cya 5.0 & 0.8550 \\
\hline & 6 & m9cya 6.0 & 0.8523 \\
\hline & 7 & m9cya 7.0 & 0.8491 \\
\hline & 8 & m9cya 8.o & 0.8450 \\
\hline & 9 & m9cya 9.0 & 0.8426 \\
\hline & 10 & m9cya 10.0 & 0.8386 \\
\hline & 100 & m9cya_100.o & 0.7472 \\
\hline \multirow{3}{*}{ MURR (24) } & 0 & m9cy 0.0 & 0.6568 \\
\hline & 10 & $\mathrm{~m} 9 \mathrm{cy}$ 10.o & 0.6339 \\
\hline & 100 & m9cy 100.0 & 0.5721 \\
\hline \multirow{3}{*}{ MIT (30) } & 0 & m9cymi_0.o & 0.7013 \\
\hline & 10 & m9cymi_10.o & 0.6893 \\
\hline & 100 & m9cymi_100.o & 0.6261 \\
\hline \multirow{3}{*}{ ORR-MEU (30) } & 0 & m9cyo 0.0 & 0.6960 \\
\hline & 10 & m9cyo 10.0 & 0.6729 \\
\hline & 100 & m9cyo_100.o & 0.6281 \\
\hline
\end{tabular}


EDF-NSNF-068

Revision 0

Page 54 of 84

Title: Criticality Analysis for Proposed Maximum Fuel Loading in a Standardized SNF Canister with Type 1a Baskets

Flooded Transport Cask

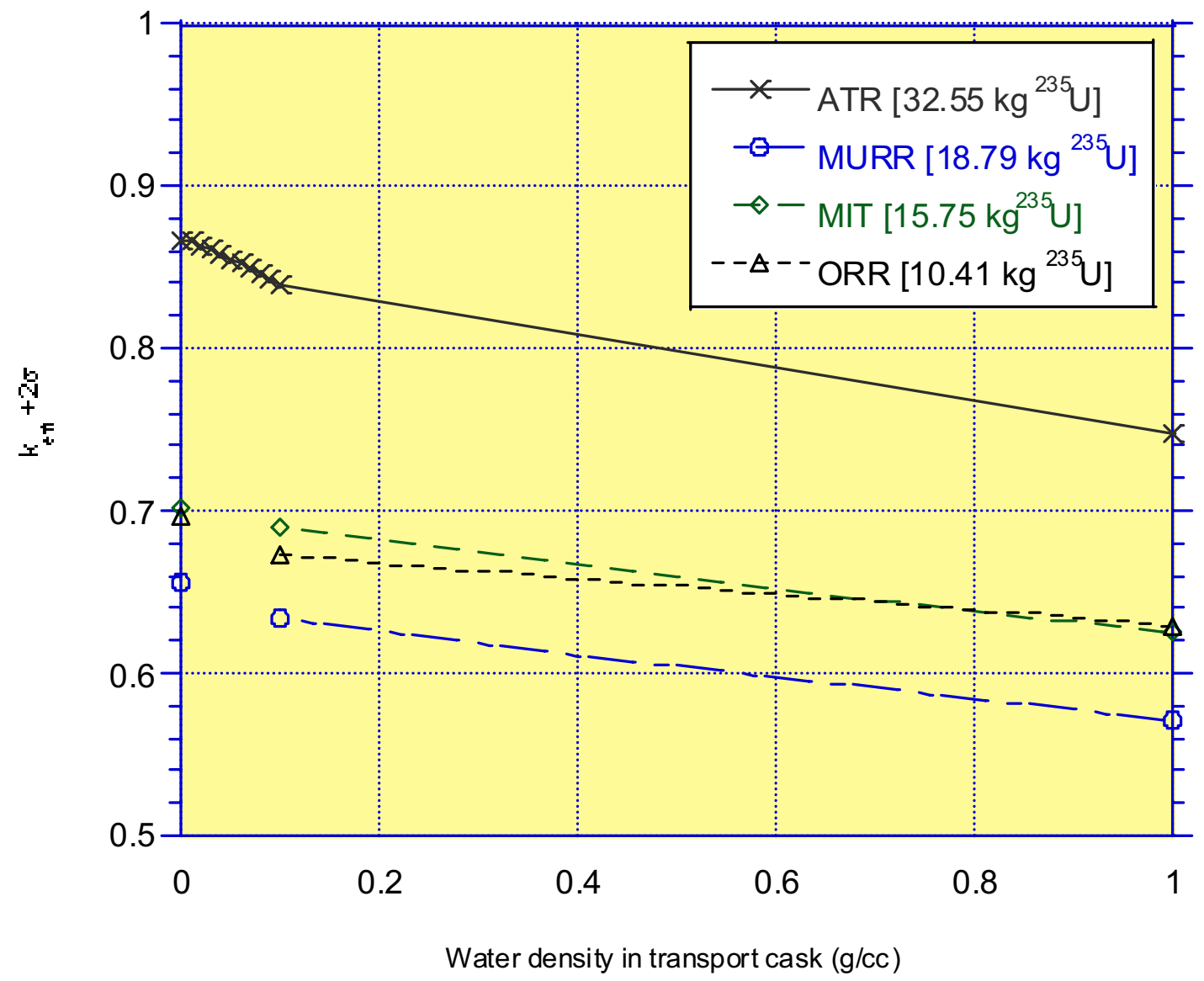

Figure 7.4-1. Flooded transport cask with degraded fuel in most reactive (cylindrical- vertical) SNF ninepack canister.

Follow-up calculations addressed reactivities for a combination of flooded cask and/or canisters with intact internals. Using the ATR(30) model, configurations were examined in both nine-pack and seven-pack arrays as shown in Figures 7.4-2a and 7.4-2b respectively. The seven-pack array provides a better probability of being able to fit the canisters inside a transport cask. Result show that the hex array configuration modeled in the seven-pack proved just as reactive as the nine-pack array in spite of the $22 \%$ decrease in fissile load in the transport cask.

The intact analyses examined: (1) dry canisters / dry cask, (2) dry canisters / flooded cask, (3) flooded canisters / flooded cask, and (4) flooded canisters / dry cask [the differentially flooded case]. As displayed in Table 7.4-2, all conditions remained subcritical. Two special cases were analyzed without the benefit of Gd-poisoned basket materials inside the SNF canisters (300 series stainless steel substituted); while reactivity increased substantially for the loaded cask, the results remained below any expected 
Revision 0

Page 55 of 84

Title: Criticality Analysis for Proposed Maximum Fuel Loading in a Standardized SNF Canister with Type 1a Baskets

subcritical limit. These specific results reinforce the concept that poisoning of the canisters is needed to support only the hypothetical degradation scenarios associated with post-closure conditions in the repository. Whether transportation requirements allow credit for only a portion of installed poisons or none at all in the SNF canister appears to be a moot point.

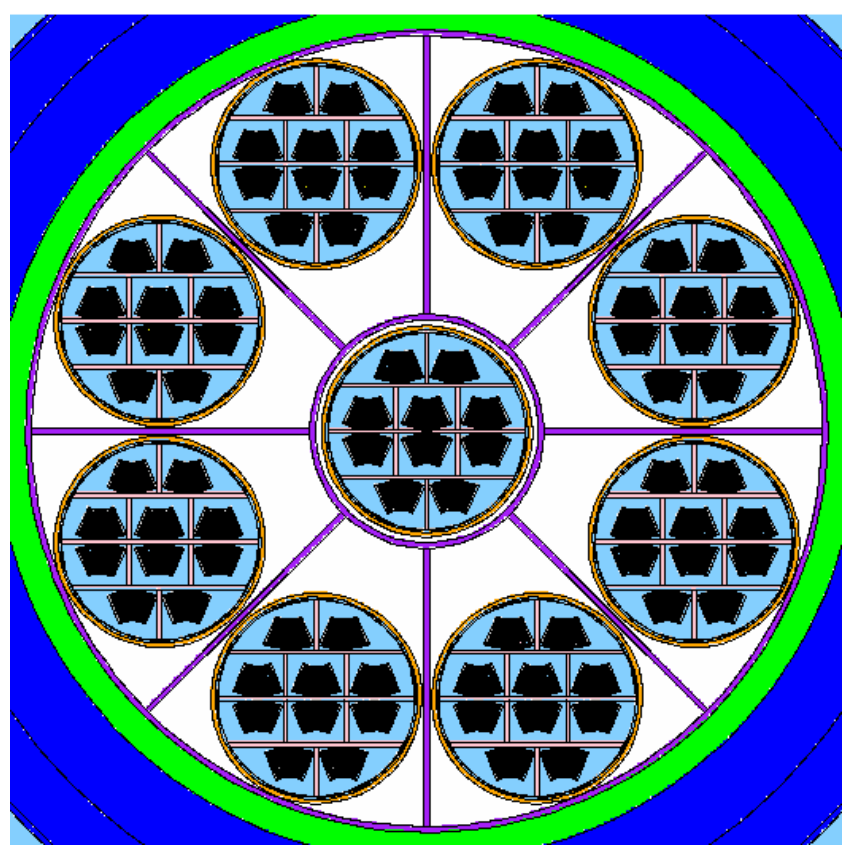

Figure 7.4-2a Nine-pack transport cask array 
Title: Criticality Analysis for Proposed Maximum Fuel Loading in a Standardized SNF Canister with Type 1a Baskets

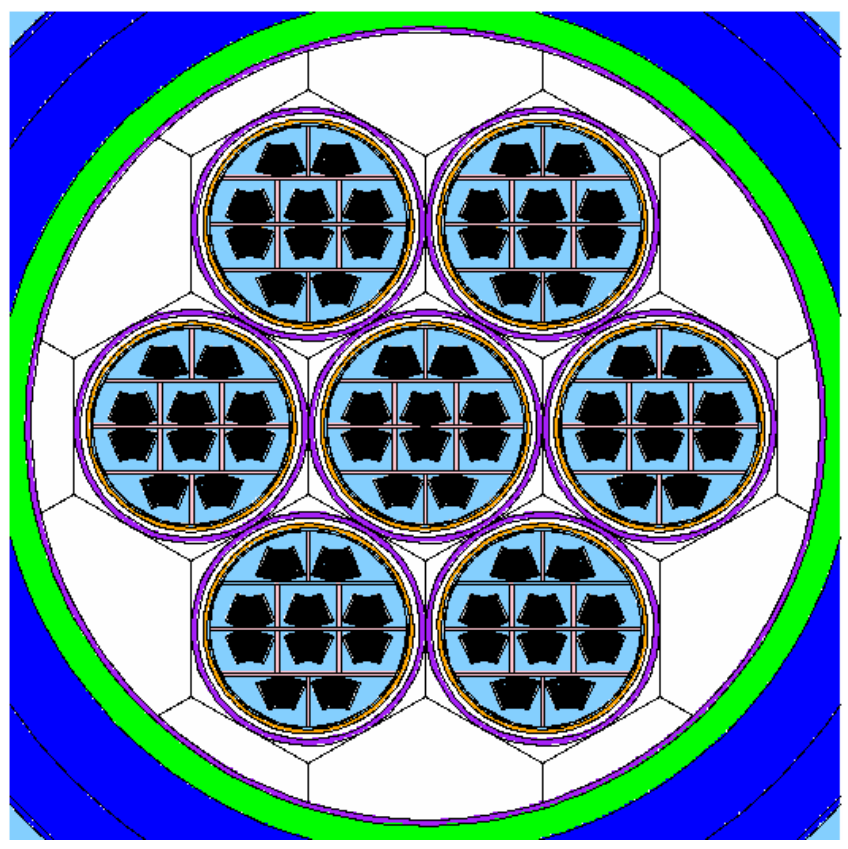

Figure 7.4-2b Seven-pack transport cask array

Table 7.4-2 Reactivities of ATR(30) loaded fuel canisters $\mathrm{w} /$ intact internals inside a transport cask 9-pack canister array - fuel baskets (ANA w/ $2 \% \mathrm{Gd}$ ) and fuels intact
Cask --> - dry
- flooded

$\begin{array}{cc} & \left(\mathrm{k}_{\mathrm{eff}}+2 \sigma\right) \\ \text {-dry } \quad & 0.2710\end{array}$
Code case
csk9int_dd.o
$\left(\mathrm{k}_{\mathrm{eff}}+2 \sigma\right)$
0.1876

\section{Code case}
csk9int_wd.o

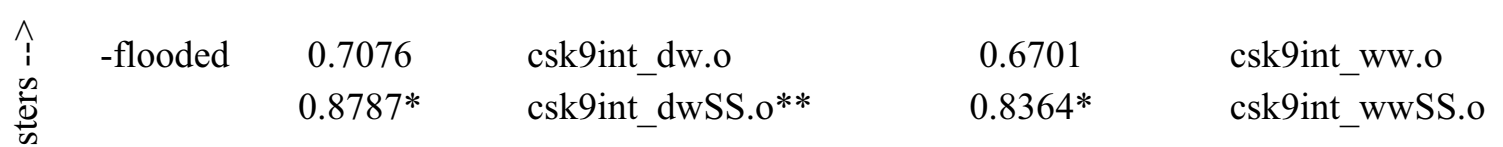

7-pack (hex) canister array- fuel baskets (ANA w/ 2\% Gd) and fuels intact

-flooded

$$
\begin{array}{cl}
0.7036 & \text { csk7int_dwH.o } \\
0.8776^{*} & \text { csk7int_dwHSS.o** }
\end{array}
$$

* SS basket rather than ANA

** Differentially flooded 'worst case' 
NATIONAL SPENT NUCLEAR FUEL PROGRAM ENGINEERING DESIGN FILE

EDF-NSNF-068

Revision 0

Page 57 of 84

Title: Criticality Analysis for Proposed Maximum Fuel Loading in a Standardized SNF Canister with Type 1a Baskets

As shown in the dry canister/dry cask case, the reactivity of the loaded cask (whether a seven- or nine-pack) is relatively benign given any non-moderated neutrons in the package. Addition of water into the transport cask (but with dry canisters) drops the calculated reactivity from $0.2710 \rightarrow 0.1876$ due to the added neutronic isolation provided between canisters. Thermalization of neutrons under these circumstances makes their incidental capture more likely. Addition of water to the flooded canisters inside the flooded cask shows an appreciable but still acceptable increase in system reactivity $(0.6701)$; the thermalization of neutrons also increases the effectiveness of the Gd poisoning present in the basket material. In the differentially flooded case (canisters flooded / cask dry), the reactivity increases $(0.6701$ $\rightarrow 0.7076$ ) with the decrease in the neutronic isolation between canisters. Yet even without poisoning in the basket material as modeled with stainless steel in place of ANA material, the calculated reactivity remains subcritical $\left(\mathrm{k}_{\mathrm{eff}}<0.90\right)$.

Dimensional constraints within a nine-pack loading in a transport cask suggested a smaller array might be required to assure an ability to actually load a transport cask. Such an array used the same wall compartment thickness between canisters ( 0.50 " 300 series stainless steel). Even with removal of 22.2\% of the fissile material in a transports cask, the resulting hex array proved as reactive as the nine-pack array in its most reactive (differentially flooded) case because of better neutronic coupling between the canisters. Yet this configuration can still remain subcritical, even with the removal of Gd poisoning from the canister baskets. If needed, the reactivity of the loaded cask can be further reduced by increased spacing between canisters or use of a poisoned cask insert. 
Page 58 of 84

Title: Criticality Analysis for Proposed Maximum Fuel Loading in a Standardized SNF Canister with Type 1a Baskets

\subsection{Benchmark Evaluations}

NSNFP has proposed use of the TSUNAMI computer code to identify applicable benchmark experiments to aid in determining an appropriate calculational bias. The TSUNAMI-3D sensitivity and uncertainty calculation sequence in SCALE 5 [SCALE 2005] was used to determine whether currently available benchmark experiments adequately cover the application cases.

TSUNAMI is a software code that allows for comparison of existing criticality benchmarks through a range-of-applicability analysis. The following is from a TSUNAMI training document [SCALE 2005, pg. 4]:

\section{Integral Indices Assess Similarity}

- $\quad$ Correlation coefficient, $\mathrm{c}_{\mathrm{k}}$, gives degree of shared variance in $\mathrm{k}_{\mathrm{eff}}$ between design application and benchmark experiment. Requires cross-section covariance data.

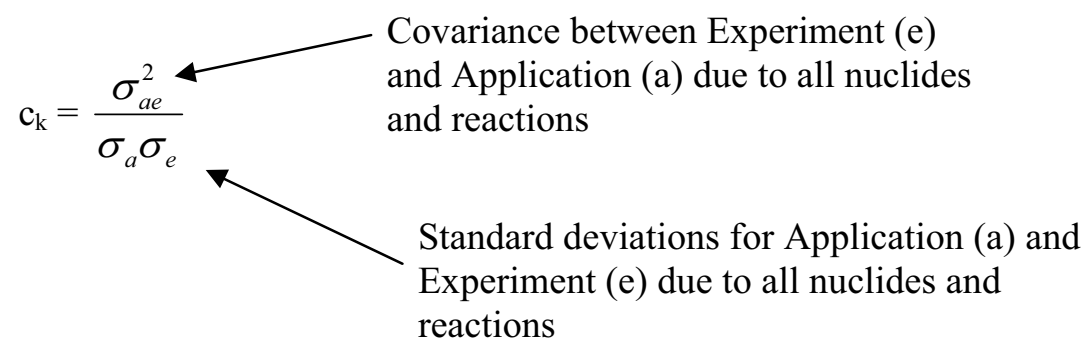

\section{Acceptance Criteria for $c_{k}$}

- Values of $c_{\mathrm{k}}$ relating a single experiment to a single application:

- $\quad 1.0$ systems are identical

- $\quad 0.0$ systems completely different

- $\quad 0.9$ - 1.0 systems are similar

- $\quad 0.8$ - 0.9 systems may be similar

- $\quad$ (80-90\% of uncertainty is common to both systems). 
Page 59 of 84

Title: Criticality Analysis for Proposed Maximum Fuel Loading in a Standardized SNF Canister with Type 1a Baskets

The criticality calculations for the spherical and cylindrical model used the MCNP $4 \mathrm{~b}$ code. The use of TSUNAMI requires a KENO model when calculating both the application and benchmark cases, the two most reactive cases were selected and converted from MCNP into KENO input format. These cases are (1) a SNF canister model with spherical degraded ATR fuel with water in fuel (sph_0) and (2) a SNF canister model with cylindrical degraded ATR fuel with water in fuel (cyl_0+ca). To represent the dry system, water reflection outside the canister was removed. Table 7.5.1 shows a side-by-side comparison of the $\mathrm{k}_{\mathrm{eff}} \mathrm{s}$ for the MCNP and KENO codes for both the spherical and cylindrical models. The MCNP models used ENDF/B-V continuous cross sections with light water hydrogen scattering. The KENO model used 238 energy group ENDF/B-V cross sections.

Table 7.5-1. Comparison of MCNP and KENO models.

\begin{tabular}{ccc}
\hline Model & MCNP & KENO V.a \\
\hline Spherical Fuel Model & $0.4189 \pm 0.0005$ & $0.4234 \pm 0.0006$ \\
Cylindrical Fuel Model & $0.4987 \pm 0.0006$ & $0.5081 \pm 0.0003$ \\
\hline
\end{tabular}

The calculated difference between MCNP and KENO for the spherical model is:

$$
k_{\text {eff }} \% \text { Difference }=\frac{0.4234-0.4189}{0.4189} \times 100=1.1 \%
$$

The calculated difference between MCNP and KENO for the cylindrical model is:

$$
k_{\text {eff }} \% \text { Difference }=\frac{0.5078-0.4987}{0.4987} \times 100=1.8 \%
$$

The TSUNAMI-3D sequence calculates the forward and adjoint angular flux and then performs first order linear perturbation to determine cross-section sensitivity. Because the neutron spectrum is quite hard, the adjoint calculation requires significantly higher number of neutrons per generation (approximately 80,000) than in the forward case. This is necessary to achieve agreement between the forward $\mathrm{k}_{\text {eff }}$ and the adjoint $\mathrm{k}_{\text {eff. }}$. The model used the TSUNAMI default of $\mathrm{S}_{10}$ quadrature for calculating the angular flux. Also, it must be noted that the geometry models require subdivision using spherical or cylindrical shells. The geometry subdivision is needed to obtain adequate resolution of the forward and adjoint angular flux. Accurate forward and adjoint flux values are essential for the perturbation calculation, which is the key to TSUNAMI results.

Examination of the TSUNAMI-3D produced sensitivity data file associated with the spherical application model (see Figure 7.5-1) shows that the ${ }^{235} \mathrm{U}$ fission cross-section sensitivity dominates. However, the hydrogen scattering and aluminum scattering sensitivities are comparable to the ${ }^{235} \mathrm{U}$ fission sensitivity over much of the energy spectrum. 
Title: Criticality Analysis for Proposed Maximum Fuel Loading in a Standardized SNF Canister with Type 1a Baskets

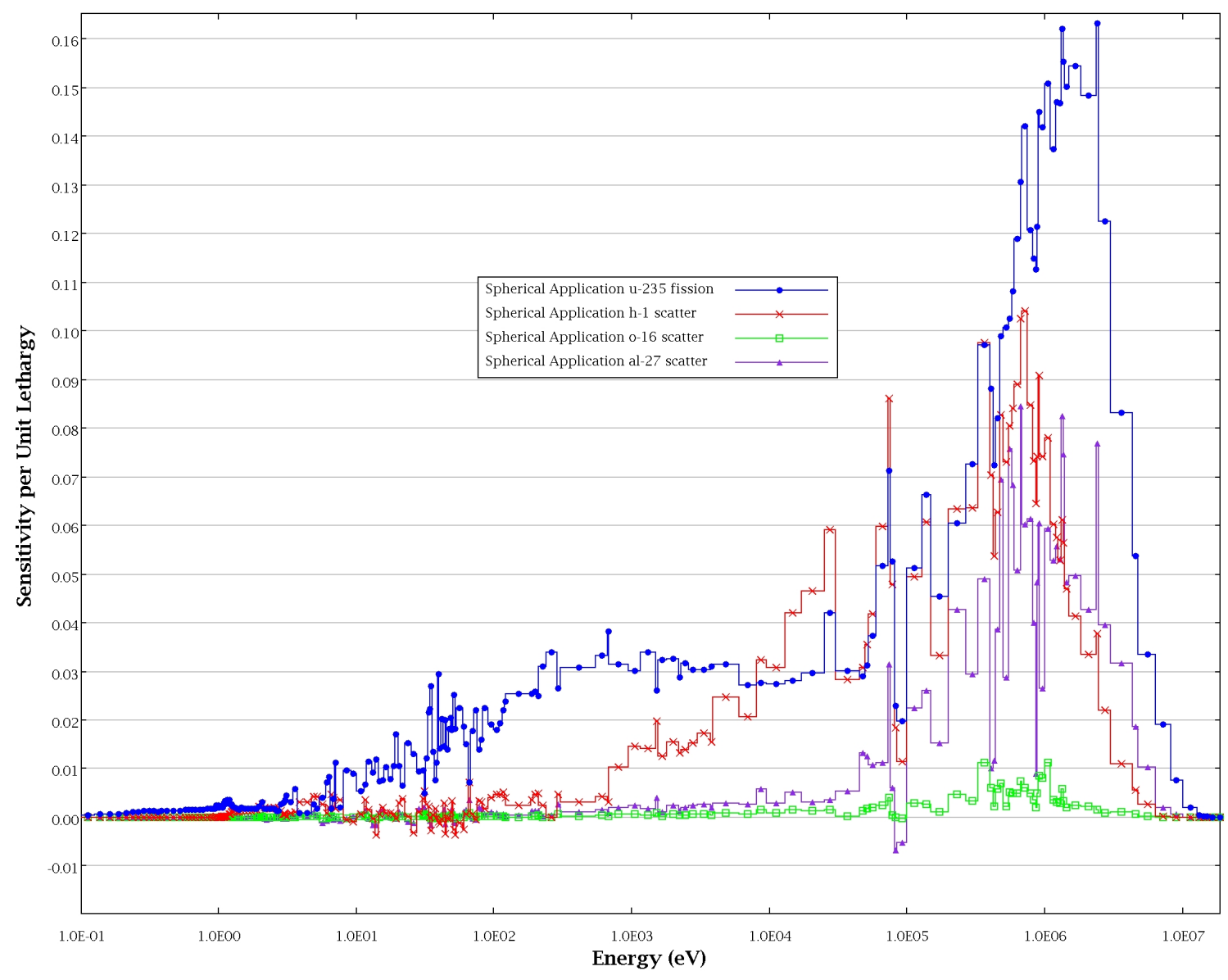

Figure 7.5-1. Scattering sensitivities.

\subsubsection{Applicability of Benchmark Experiments}

The analyses for the axial reconfiguration of ATR fuel matrix material away from the poisoned basket materials suggests benchmark experiments, such as GODIVA or other HEU fast systems, may be applicable. However, unlike GODIVA, the application cases are not devoid of hydrogen. For instance the spherical assembly model $\mathrm{H} / \mathrm{X}$ ratio is 2.1 . Furthermore, the aluminum content of the application cases is quite high. For instance, the $\mathrm{Al} / \mathrm{X}$ ratio is 14.5 for the spherical assembly model. Thus, several other benchmark experiments were selected from the International Handbook of Evaluated Criticality Safety Benchmark Experiments (ICSBE) (ICSBE 2004).

The TSUNAMI-3D and the TSUNAMI-IP calculations were performed for the two SNF canister models to determine area of applicability. Because the canister models are fast systems, fast benchmark experiments from the ICSBE Handbook (ICSBE 2004) were examined. Initially, six evaluations from the Handbook were selected, and the TSUNAMI-3D and TSUNAMI-IP runs were made to calculate correlation coefficient, $c_{k}$. The models selected for evaluations are listed in Table 7.5-2. 
Title: Criticality Analysis for Proposed Maximum Fuel Loading in a Standardized SNF Canister with Type 1a Baskets

Table 7.5-2. Initial comparison models.

Benchmark Experiment

I.D.

Description

HEU-MET-FAST-001

HEU-MET-FAST-007

HEU-MET-FAST-021

HEU-MET-FAST-022

HEU-MET-FAST-065

HEU-MET-MIXED-005
Bare, HEU sphere experiment (GODIVA) performed at Los Alamos National Laboratory.

$\mathrm{U}_{\text {metal slabs moderated with polyethylene, Plexiglas }}{ }^{\circledR}$, and Teflon ${ }^{\circledR}$ experiments performed at Oak Ridge National Laboratory. Case 2 was evaluated.

Steel reflected spherical assembly of U-235 (90\%) experiment performed at VNIIEF.

Duralumin reflected spherical assembly of U-235 (90\%) experiment performed at VNIIEF.

Unreflected cylinder of HEU experiment performed by VNIIEF.

Critical experiments with heterogeneous compositions of HEU, $\mathrm{SiO}_{2}$, and polyethylene performed in the Institute of Physics and Power Engineering (IPPE) at the Big Physical Stand (BFS) facility.

Five experiments were evaluated.

Fourteen cases were subsequently evaluated, as shown in Table 7.5-3. In some cases, the water in the fuel was removed to compare the $c_{k}$ values; $c_{k}$ ranged from 0.34 to 0.90 . The most similar system was Case 5 of the BFS experiments (BFS-79-5 2000). In literally all cases, the MCNP calculated a higher reactivity when compared to the KENO model.

Table 7.5-3. $\mathrm{c}_{\mathrm{k}}$ values and $\mathrm{k}_{\mathrm{eff}}$ 's for application and benchmark experiments.

\begin{tabular}{|l|l|c|c|c|}
\hline \multicolumn{1}{|c|}{$\begin{array}{c}\text { Benchmark } \\
\text { Experiment }\end{array}$} & \multicolumn{1}{c|}{ Application } & $\begin{array}{c}\text { MCNP 4b, } \\
\mathrm{k}_{\mathrm{eff}}+2 \sigma\end{array}$ & $\begin{array}{c}\text { KENO V.a, } \\
\mathrm{k}_{\mathrm{eff}}+2 \sigma\end{array}$ & $\mathrm{c}_{\mathrm{k}}$ \\
\hline $\begin{array}{l}\text { GODIVA } \\
\text { (HEU-MET-FAST-001) }\end{array}$ & $\begin{array}{l}\text { SNF canister model with cylindrical } \\
\text { degraded ATR fuel with water in fuel }\end{array}$ & 0.9986 & 0.9978 & 0.48 \\
\hline $\begin{array}{l}\text { GODIVA } \\
\text { (HEU-MET-FAST-001) }\end{array}$ & $\begin{array}{l}\text { SNF canister model with cylindrical } \\
\text { degraded ATR fuel without water in fuel }\end{array}$ & 0.9986 & 0.9978 & 0.73 \\
\hline $\begin{array}{l}\text { ORNL } \\
\text { (HEU-MET-FAST-007) }\end{array}$ & $\begin{array}{l}\text { SNF canister model with cylindrical } \\
\text { degraded ATR fuel without water in fuel }\end{array}$ & 0.9973 & 0.9944 & 0.67 \\
\hline $\begin{array}{l}\text { VNIIEF } \\
\text { (HEU-MET-021) }\end{array}$ & $\begin{array}{l}\text { SNF canister model with cylindrical } \\
\text { degraded ATR fuel with water in fuel }\end{array}$ & 1.0082 & 1.0055 & 0.84 \\
\hline $\begin{array}{l}\text { VNIIEF } \\
\text { (HEU-MET-065) }\end{array}$ & $\begin{array}{l}\text { SNF canister model with cylindrical } \\
\text { degraded ATR fuel with water in fuel }\end{array}$ & 0.9976 & 0.9968 & 0.85 \\
\hline $\begin{array}{l}\text { BFS-79-1 } \\
\text { (HEU-MET-MIXED-005) }\end{array}$ & $\begin{array}{l}\text { SNF canister model with cylindrical } \\
\text { degraded ATR fuel with water in fuel }\end{array}$ & 1.0139 & 0.9994 & 0.79 \\
\hline BFS-79-2 & SNF canister model with cylindrical & 1.0239 & 1.0045 & 0.66 \\
\hline
\end{tabular}


NATIONAL SPENT NUCLEAR FUEL PROGRAM ENGINEERING DESIGN FILE

EDF-NSNF-068

Revision 0

Page 62 of 84

Title: Criticality Analysis for Proposed Maximum Fuel Loading in a Standardized SNF Canister with Type 1a Baskets

\begin{tabular}{|l|l|c|c|c|}
\hline \hline \multicolumn{1}{|c|}{$\begin{array}{c}\text { Benchmark } \\
\text { Experiment }\end{array}$} & \multicolumn{1}{c|}{ Application } & $\begin{array}{c}\text { MCNP 4b, } \\
\mathrm{k}_{\text {eff }}+2 \sigma\end{array}$ & $\begin{array}{c}\text { KENO V.a, } \\
\mathrm{k}_{\text {eff }}+2 \sigma\end{array}$ & $\mathrm{c}_{\mathrm{k}}$ \\
\hline (HEU-MET-MIXED-005) & degraded ATR fuel with water in fuel & 1.0008 & 0.34 \\
\hline $\begin{array}{l}\text { BFS-79-3 } \\
\text { (HEU-MET-MIXED-005) }\end{array}$ & $\begin{array}{l}\text { SNF canister model with cylindrical } \\
\text { degraded ATR fuel with water in fuel }\end{array}$ & 1.0199 & 1.0067 & 0.85 \\
\hline $\begin{array}{l}\text { BFS-79-4 } \\
\text { (HEU-MET-MIXED-005) }\end{array}$ & $\begin{array}{l}\text { SNF canister model with cylindrical } \\
\text { degraded ATR fuel with water in fuel }\end{array}$ & 1.0170 & 0.9953 & 0.91 \\
\hline $\begin{array}{l}\text { BFS-79-5 } \\
\text { (HEU-MET-MIXED-005) }\end{array}$ & $\begin{array}{l}\text { SNF canister model with cylindrical } \\
\text { degraded ATR fuel with water in fuel }\end{array}$ & 1.0074 & 0.9978 & 0.62 \\
\hline $\begin{array}{l}\text { GODIVA } \\
\text { (HEU-MET-FAST-001) }\end{array}$ & $\begin{array}{l}\text { SNF canister model with spherical } \\
\text { degraded ATR fuel with water in fuel }\end{array}$ & 0.9986 & 0.9968 & 0.61 \\
\hline $\begin{array}{l}\text { VNIIEF (HEU-MET-065) } \\
\text { SNF canister model with spherical } \\
\text { degraded ATR fuel with water in fuel }\end{array}$ & $\begin{array}{l}\text { SNF canister model with spherical } \\
\text { degraded ATR fuel with water in fuel }\end{array}$ & 0.9976 & 0.9934 & 0.64 \\
\hline $\begin{array}{l}\text { VNIIEF } \\
\text { (HEU-MET-FAST-022) }\end{array}$ & $\begin{array}{l}\text { SNF canister model with spherical } \\
\text { degraded ATR fuel with water in fuel }\end{array}$ & 1.0074 & 0.9953 & 0.86 \\
\hline $\begin{array}{l}\text { BFS-79-5 } \\
\text { (HEU-MET-MIXED-005) }\end{array}$ & & \\
\hline
\end{tabular}

Figure 7.5-2 shows the ${ }^{235} \mathrm{U}$ fission cross-section sensitivity for the spherical model application case compared with the duralumin reflected U sphere (HEU-MET-FAST-022) and the heterogeneous Institute of Physics and Power Engineering (IPPE) experiment (HEU-MET-MIXED-005). The figure shows that the duralumin reflected sphere and IPPE experiments envelop the ${ }^{235} \mathrm{U}$ fission cross-section sensitivity for the spherical application case. 
Title: Criticality Analysis for Proposed Maximum Fuel Loading in a Standardized SNF Canister with Type 1a Baskets

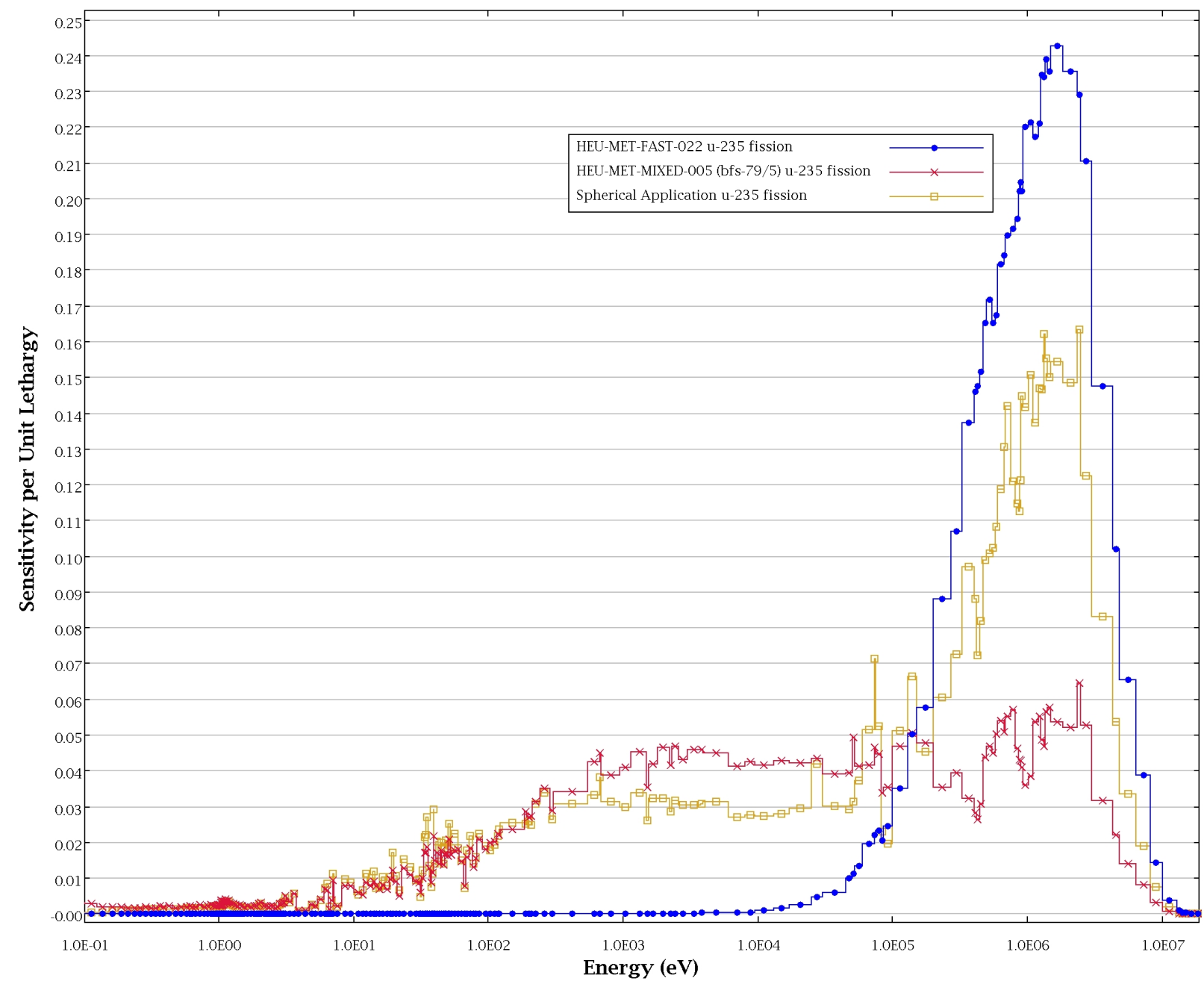

Figure 7.5-2. Cross-section sensitivity model comparisons.

Figure 7.5-3 shows the ${ }^{27} \mathrm{Al}$ scattering cross-section sensitivity for the spherical model application case compared with the duralumin reflected U sphere (HEU-MET-FAST-022) and the heterogeneous IPPE experiment (HEU-MET-MIXED-005). The figure shows that the IPPE experiment is relatively insensitive to the ${ }^{27} \mathrm{Al}$ scattering cross section. The duralumin reflected experiment shows comparatively significant sensitivity to the ${ }^{27} \mathrm{Al}$ scattering cross section, but it does not envelope the ${ }^{27} \mathrm{Al}$ scattering cross-section sensitivity for the spherical model application. 
Page 64 of 84

Title: Criticality Analysis for Proposed Maximum Fuel Loading in a Standardized SNF Canister with Type 1a Baskets

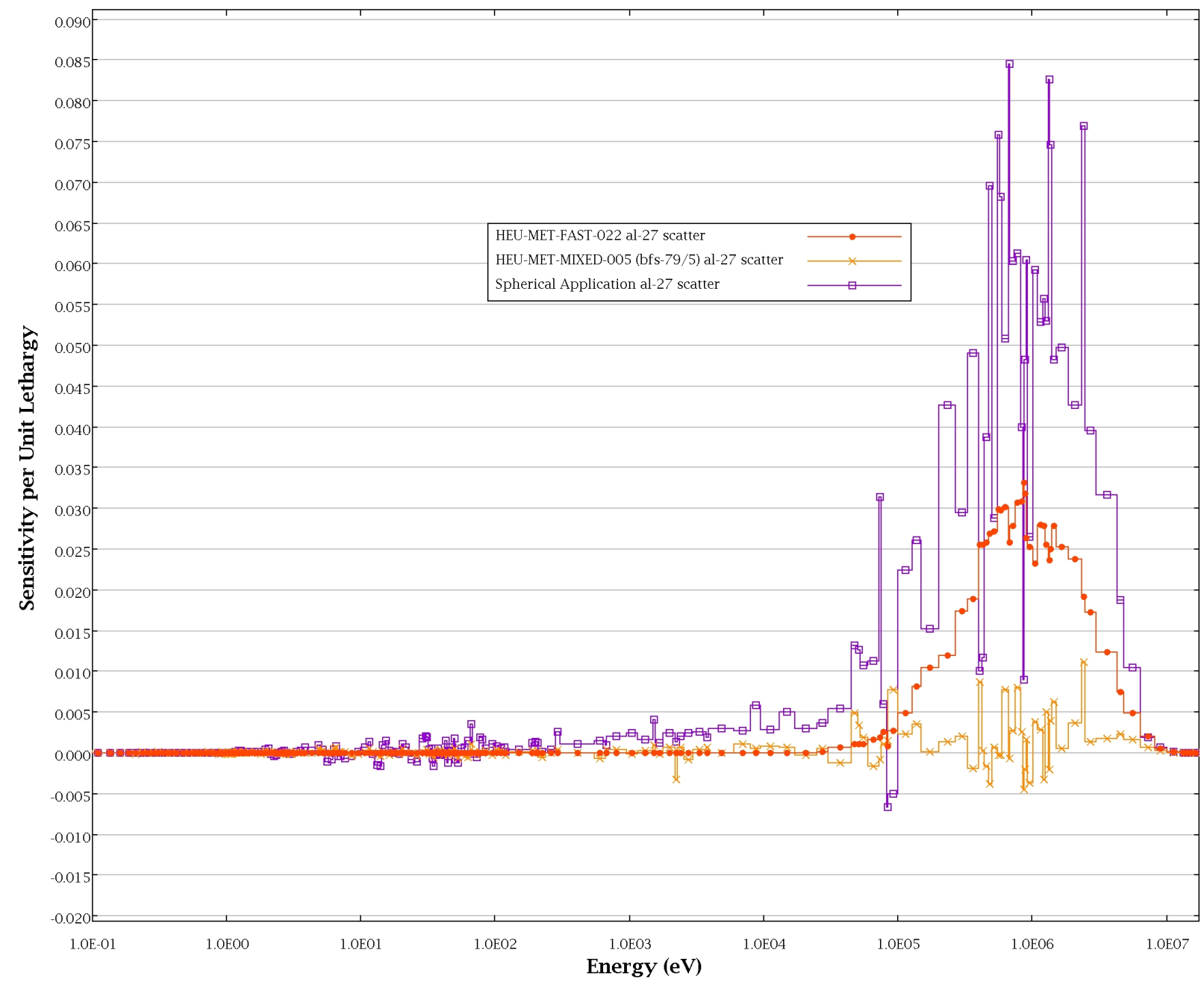

Figure 7.5-3. ${ }^{27} \mathrm{Al}$ scattering cross-section sensitivity.

Figure 7.5-4 shows the hydrogen scattering cross-section sensitivity for the spherical model application case compared with the heterogeneous IPPE experiment. The duralumin reflected experiment did not contain hydrogen. The figure shows that the IPPE experiment is relatively insensitive to the hydrogen scattering cross section and does not envelope the sensitivity for the spherical model application. 
Title: Criticality Analysis for Proposed Maximum Fuel Loading in a Standardized SNF Canister with Type 1a Baskets

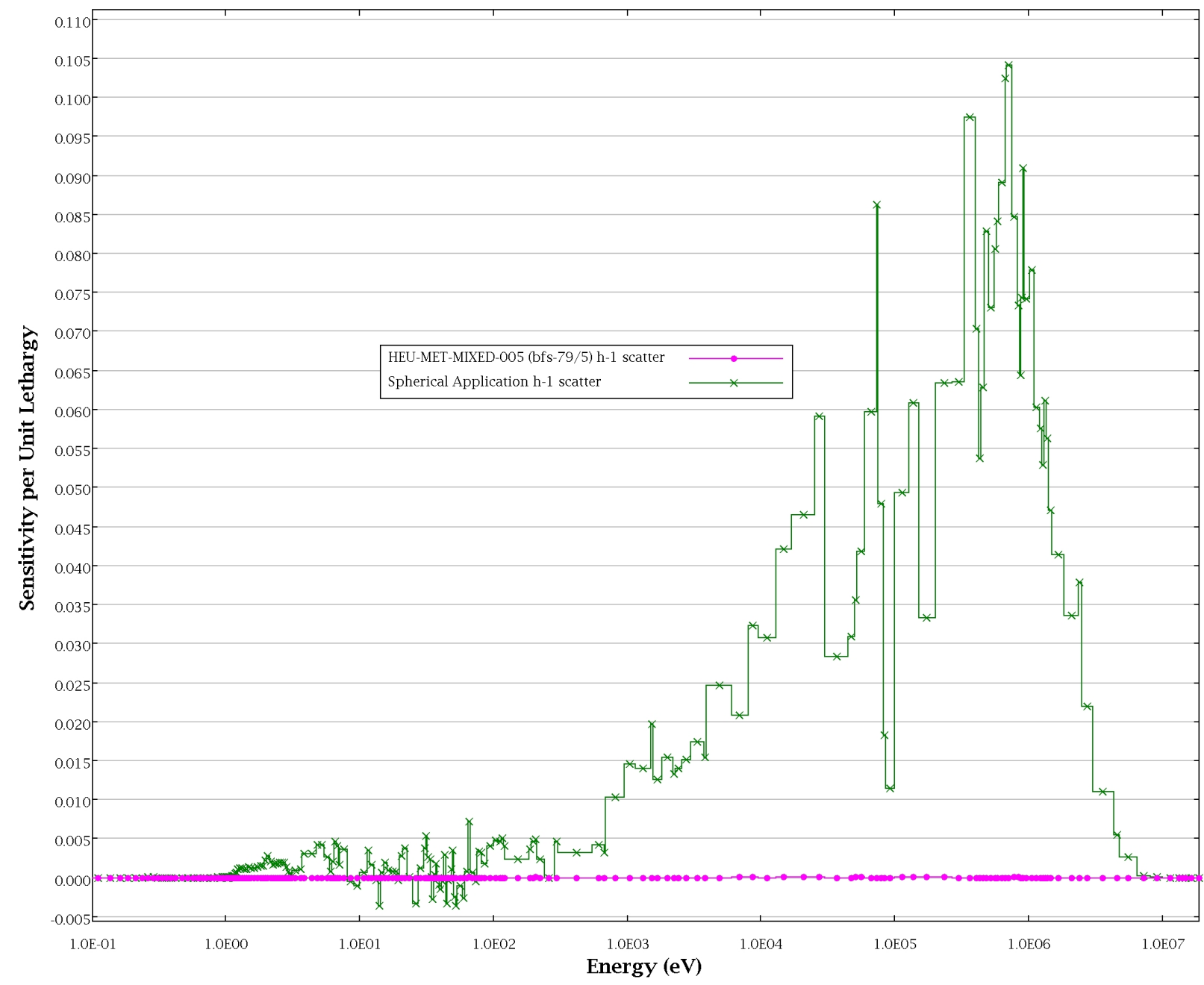

Figure 7.5-4. Hydrogen scatter sensitivity.

Directly out of the HEU-MET-MIXED-005 report, Section 4.0, Results of Sample Calculations states: "Many of the calculated results presented in Table 6 exceed the benchmark-model $\mathrm{k}_{\text {eff }}$ value by over 1\%. The specific reasons for this are unknown." So even this best specific benchmark has a degree of uncertainty associated with the reactivity measurements. The HEU-MET-MIXED-005 contains some $\mathrm{Fe}$ in the system, heterogeneous $\mathrm{SiO}_{2}$ with Al-clad HEU pucks, and slightly higher moderation rather than homogeneous $\mathrm{UAl}_{\mathrm{x}}$ models.

The spherical and cylindrical shapes of the debris modeled for the ATR fuels are represented with the $\mathrm{UAl}_{\mathrm{x}} / \mathrm{Al}$ fuel matrix from within the plates of the ATR assembly. As such, these models are represented by a homogenous reconfiguration of the matrix material. The HEU-MET-MIXED-005, which provides the highest $c_{\mathrm{k}}$, is a heterogeneous, large-core reactor configuration. The canister model with degraded ATR fuel is basically a dry, fast system of rather small volume. 


\section{NATIONAL SPENT NUCLEAR FUEL PROGRAM ENGINEERING DESIGN FILE}

EDF-NSNF-068

Revision 0

Page 66 of 84

Title: Criticality Analysis for Proposed Maximum Fuel Loading in a Standardized SNF Canister with Type 1a Baskets

Based on the initial TSUNAMI calculation results, there appears to be insufficient availability of applicable benchmark critical experiments to quantitatively establish a calculation bias for the criticality scenarios under consideration. However, the TSUNAMI results confirm that applicable critical benchmark experiments are available for the dominant cross section of concern for the application cases, such as ${ }^{235} \mathrm{U}$ fission. The lack of identified applicable benchmark experiments for ${ }^{27} \mathrm{Al}$ and hydrogen suggests that a calculation bias should be applied. Furthermore, it appears that calculations for the application cases performed with MCNP may tend to be approximately $2 \%$ less than the calculation results obtained from KENO. Therefore, an added calculation bias of $5 \%$ is considered sufficient to ensure conservative results.

Based on the initial TSUNAMI calculations, no experiments in the ICSBE Handbook adequately represent the characteristics of this dry ${ }^{235} \mathrm{U} / \mathrm{Al}$ system. Without meaningful comparative benchmarks, parameters such as pitch-to-rod diameter, assembly separation, and presence of neutron absorber material are inconsequential to establishing viable benchmarks for the dry ${ }^{235} \mathrm{U} / \mathrm{Al}$ system. A more comprehensive TSUNAMI analysis may involve examination of over 100 benchmark experiments without yielding any other or more meaningful benchmarks given the relatively few 'dry' critical benchmarks.

The 5\% bias and uncertainties typically assigned to established benchmarks cannot be supported with these analyses when dealing with this dry, critical system. However, given the conservatisms already incorporated in the ${ }^{235} \mathrm{U} / \mathrm{Al}$ model, a negotiated administrative margin of perhaps $5 \%$ could be added to such a non-benchmarked system so that a subcritical limit with a $k_{\text {eff }}+2 \sigma$ less than 0.90 is considered to provide a suitable margin of safety.

\section{Summary}

Four different aluminum plate fuel types were analyzed in a leak-tight standardized DOE SNF canister, with internal conditions ranging from intact to non-mechanistic worst case scenarios. Analyses were performed for single canisters as well as a nine-pack array using the most reactive single canister. The reactivity of the various dry-fuel configurations has been shown to be a direct function of the fissile mass per canister and the most consolidated fissile mass.

\subsubsection{Intact Cases}

A 15-ft. canister loading configuration containing three Type 1a baskets, each basket containing 10 ATR fuel assemblies, is considered the limiting case from a criticality safety perspective. This configuration will establish the canister loading limits in terms of total fissile (kg) and linear loading $(\mathrm{g} / \mathrm{cm})$ within the canister. As such, this configuration is expected to bound any other fuel type(s) that will be loaded into a canister using a Type la basket.

Analyses for intact fuels were completed for a single, dry as-loaded canister for four different aluminum plate fuels, such as ATR, MURR, ORR, and MIT utilizing a Type 1a basket. For comparison purposes, the same canister model was also analyzed without the presence of $\mathrm{Gd}$ in the basket plate material. In none of these cases did the calculated reactivity, as measured by $k_{\text {eff }}+2 \sigma$ rise above 0.20 . All analyses were conducted with water (see Assumption 4.5) in the fuel matrix and full water reflection of the canister. To further demonstrate the adequacy of the criticality safety for the single canister, the 


\section{NATIONAL SPENT NUCLEAR FUEL PROGRAM ENGINEERING DESIGN FILE}

EDF-NSNF-068

Revision 0

Page 67 of 84

Title: Criticality Analysis for Proposed Maximum Fuel Loading in a Standardized SNF Canister with Type 1a Baskets

loaded canisters were also analyzed intact and fully-flooded. For the proposed canister loadings, the calculated reactivities remained below a $\mathrm{k}_{\mathrm{eff}}+2 \sigma \leq 0.6810$ when flooded.

Reactivity of the fuels has been shown to be a direct function of the fissile mass per canister. Accident conditions that might lead to axial reconfiguration of fissile material inside a vertically oriented canister are of primary concern for any canister handling prior to placement in the repository. In a moderator-excluded condition inside a loaded canister, invariably a more consolidated fissile mass produces the more reactive system.

\subsubsection{Degraded Cases}

Accident conditions that might lead to axial reconfiguration of fissile material inside a vertically oriented canister are of primary concern for transportation. Analyses for post-closure repository scenarios have already demonstrated criticality safety for horizontal configurations under fully degraded conditions. [CRWMS 2004] Analysis of canisters postulated to undergo various accident conditions during handling and transport operations considered vertical orientation with rubblization of the fuels. The accident scenarios were non-mechanistic, relying on postulated conditions to create most reactive configurations. Intermediate cases with baskets intact and fuels degraded, and basket deformation with fuels intact were also evaluated. Calculations employed a vertical canister orientation when in search of the most reactive configuration; in these vertical cases, all four fuel types were evaluated. As fuel matrix consolidation/concentration occurs, whether in the bottom of each basket or the bottom of the canister upon basket failure, subcritical limits are never exceeded under any proposed reconfiguration.

Results for degraded fuels with the vertical orientation also calculated the net effect of what void fraction in the rubble contributes or detracts from reactivity. Tables 7.2-2 and 7.2-3 (along with their accompanying figures) demonstrate that increased void fractions in the fuel rubble generate predictable decreases in reactivity due to the decreased fissile atom densities in the reactive zones in each basket. Consequently, configurations with all the fissile material concentrated into the bottom of a canister were evaluated to determine the bounding case.

Deflections of the various basket components were analyzed for increased reactivity for both sidedrops and end-drops of a canister loaded with 30 ATR assemblies. In the case of the side drop, the assumption was the compartment plates somehow fractured and settled on the intact fuels in the compartment below. This resulted in a slight increase in reactivity from 0.1367 (see Table 7.1-1; case atr30.0) to 0.1407 (see Table 7.2-5). The more reactive increase occurred with an end-drop of the ATR (30), where all the fuel matrix material from 30 ATR assemblies reconfigured in the bottom basket; this configuration assumes loss of separation between baskets because of damage to the basket base plates. Once again, the vertical reconfiguration with minimum void fraction provided the maximum calculated reactivity for the enveloping fuel (see Table 7.2-6).

For extreme cases, all loss of basket and fuel geometry allowed for formation of a spherical shape in the bottom of the canister. The spherical shape was chosen for reasons known to promote minimum critical mass because it provides the smallest surface to volume ratio contributing to neutron leakage. Reactivity increased to approximately 0.55 for a 15 -ft. canister loaded with ATR fuel (see Table 7.2-7; case sph_0.o). Analyses also examined a slightly more probable configuration with the fissile matrix debris forming a cylinder in the bottom of the canister, limited by the internal diameter of the SNF 
NATIONAL SPENT NUCLEAR FUEL PROGRAM ENGINEERING DESIGN FILE

EDF-NSNF-068

Revision 0

Page 68 of 84

Title: Criticality Analysis for Proposed Maximum Fuel Loading in a Standardized SNF Canister with Type 1a Baskets

canister itself. Because this resulted in a more reactive configuration than the spherical shape $\left(\mathrm{k}_{\mathrm{eff}}+2 \sigma\right.$ 0.6249 ), all four fuel types were analyzed in this configuration. The results for these single canister reactivities are shown in Table 7.2-8.

A confirmatory analysis examined non-mechanistically degraded ATR fuel assemblies still contained within their poisoned basket compartments, but with full flooding in the SNF canister. Given a fully loaded $15^{\prime}$ canister with ATR fuel, the typical subcritical limit of 0.95 would be exceeded, given maximal fuel rubblization and canister flooding regardless of canister orientation.

The last analyses also considered a hypothetical transport cask configuration to identify whether multiple canisters might be shipped safely. The nine-pack transportation arrays used the most reactive configuration as the input to the transport cask array calculations. The transport cask array values (see Table 7.3-1) evaluated the canisters with moderator exclusion, with $10 \%$ water density inside the transport cask and the transport cask fully flooded. Addition of water to a loaded transport cask appears to neutronically isolate the canisters. Although criticality calculations for the loaded transportation package will be done through the selected transportation cask vendor, these results indicate that with leak-tight canisters, criticality safety of the loaded cask can be demonstrated for all required transportation scenarios. Expansion of these transport cask analyses also included intact canister scenarios for all combinations of dry and flooded, both transport cask and SNF canisters. None of these calculated reactivities resulted in $\mathrm{k}_{\mathrm{eff}}+2 \sigma$ greater than 0.90 .

\subsubsection{Benchmarks}

Benchmarks for dry systems, and more particularly systems with a variety of compositions for the fissile matrix material, are virtually nonexistent.

Greater biases and uncertainties are expected for transportation, but the ability to meet the subcritical limits for transportation can very likely be met given the criticality safety margins already calculated for the configurations analyzed in this report. 
NATIONAL SPENT NUCLEAR FUEL PROGRAM ENGINEERING DESIGN FILE

EDF-NSNF-068

Revision 0

Page 69 of 84

Title: Criticality Analysis for Proposed Maximum Fuel Loading in a Standardized SNF Canister with Type 1a Baskets

\section{REFERENCES}

\subsection{Documents Cited}

Beyer, W. H., ed., 1987, CRC Standard Mathematical Tables, 28th Edition, 3rd Printing 1988, Boca Raton, Florida: CRC Press. TIC: 240507.

Briesmeister, J. F., ed., 1997, MCNP-A General Monte Carlo N-Particle Transport Code. LA-12625-M, Version 4B, Los Alamos, New Mexico: Los Alamos National Laboratory, ACC: MOL.1998064.0328.

BFS, U.S. Department of Energy, Office of Spent Fuel Management and Special Projects, Critical Experiments with Heterogeneous Compositions of Highly Enriched Uranium, Silicon Dioxide, and Polyethylene, INEEL/EXT-2000-01149, Bechtel BWXT Idaho LLC, August 2000.

CRWMS 1997a Evaluation of Codisposal Viability for Aluminum-Clad DOE-Owned Spent Fuel: Phase I Intact Codisposal Canister, BBA000000-01717-5705-00011 Rev. 00, Las Vegas, Nevada, June 1997.

CRWMS 1997b Evaluation of Codisposal Viability for Aluminum-Clad DOE-Owned Spent Fuel: Phase II Degraded Codisposal Waste Package Internal Criticality, BBA000000-01717-5705-00017 Rev. 00, Las Vegas, Nevada, December 1997.

CRWMS 1998a, Software Qualification Report for MCNP Version 4B2, A General Monte Carlo NParticle Transport Code, CSCI: 30033 V4B2LV, DI: 30033-2003, Rev. 01, Las Vegas, Nevada: ACC: MOL.19980622.0637.

CRWMS 1998b, Software Code: MCNP, V4B2LV, HP, HPUX 9.07 and 10.20; PC, Windows 95; Sun, Solaris 2.6. 30033 V4B2LV.

CRWMS 2004, Intact and Degraded Mode Criticality Calculations for the Codisposal of ATR Spent Nuclear Fuel in a Waste Package, DOC.20041018.0001, CAL-DSD-NU-000007, Rev 00A, Las Vegas, Nevada, October 2004.

DOE 1999, "Design Specifications," Volume 1 of Preliminary Design Specification for Department of Energy Standardized Spent Nuclear Fuel Canisters, DOE/SNF/REP-011, Rev. 3, Washington, D.C.: U.S. Department of Energy, Office of Spent Fuel Management and Special Projects, TIC: 246602.

DOE 2004a, Quality Assurance Requirements and Description, DOE/RW-0333P, Rev. 16, Washington, D.C.: U.S. Department of Energy, Office of Civilian Radioactive Waste Management, ACC: 20040907.0002. 
NATIONAL SPENT NUCLEAR FUEL PROGRAM ENGINEERING DESIGN FILE

EDF-NSNF-068

Revision 0

Page 70 of 84

Title: Criticality Analysis for Proposed Maximum Fuel Loading in a Standardized SNF Canister with Type 1a Baskets

DOE 2004b, Packaging Strategies for Criticality Safety for “Other” DOE Fuels in a Repository. DOE/SNF/REP-090, Rev. 0. Idaho Falls, Idaho: U.S. Department of Energy, Idaho Operations Office, ACC: MOL.20040708.0386.

DWG 237, Fuel Element, Research Reactor Facility University of Missouri, DWG 237 E 212.

DWG 409, University of Missouri at Columbia Test Research Training Reactor 4, MURR Fuel Plate

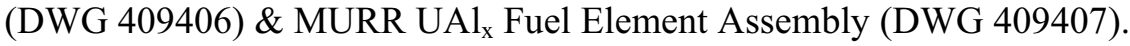

DWG 419, Massachusetts Institute of Technology Test Research Training Reactor 3 Welded Fuel Element Assembly, DWG 419486.

FRC-0022, Company internal interdepartmental communication, W. W. Gay to C. S. Olson, Fuel Receipt Criteria for Advanced Test Reactor (ATR) Fuel - WWG-12-95, July 27, 1995.

Glasstone, S. and Sesonske, A., Nuclear Reactor Engineering, D. Van Nostrand Company, Princeton, New Jersey, 1967,

ICSBE, International Handbook of Evaluated Criticality Safety Benchmark Experiments, NEA/NSC/DOC(95)03, September 2004 (or latest edition).

INEEL 2003, Specification for Advanced Test Reactor Mark VII Zone Loaded Fuel Elements, IN-F-9-ATR, Revision 15, SPC-415, Rev. 0, Idaho Falls, Idaho: U.S. Department of Energy, ACC: DOC.20040818.0003.

Knight, R. W., Observations in the Manufacture of Aluminum-Based Research Reactor Fuel Elements, ORNL/TM-11809, Oak Ridge National Laboratory, Tennessee, 1993.

MCNP 5 Monte Carlo N-Particle Transport Code System, Los Alamos National Laboratory, Los Alamos, New Mexico, distributed by RSIC, P.O. Box 2008, Oak Ridge, TN 37831-6362.

NSNFP, Software Control, NSNFP 19.01, Rev. 4, August 2005

OBU-NMM-2003-00109, Appendix A data set from Savannah River Site, 2003.

OR-001, M-11495-OR-001 “19 Plate Fuel Element Assy and Finish Machining”

OR-003, M-11495-OR-003 "Misc. Details for ORR Fuel Element”

OR-004, M-11495-OR-004 "Fuel Plate Details"

Paige, B. E., 1969, Description of Test Reactor Fuel Elements and Associated Behavior in Reprocessing, CI-1152, Idaho Falls, ID, U.S. Atomic Energy Commission, Idaho Operations Office, ACC: MOL.20040303.0031. 
Revision 0

Page 71 of 84

Title: Criticality Analysis for Proposed Maximum Fuel Loading in a Standardized SNF Canister with Type 1a Baskets

Parrington, J. R., H. D. Knox, S. L. Breneman, E. M. Baum, and F. Feiner, 1996, Nuclides and Isotopes, Chart of the Nuclides, 15th Edition, San Jose, California: General Electric Company and KAPL, Inc., TIC: 233705.

Reed, J. D., L. V. Wages, A. J. Vinnola, G. N. Fillmore, and E. C. Anderson, Sr., 1992. Specification for Reactor Grade High Enriched Uranium Aluminide (UAI $)_{x}$ Powder. IN-F-5-TRA, Rev. 9. Idaho Falls, Idaho: EG\&G Idaho Inc., TIC: 256484.

SCALE: A Modular Code System for Performing Standardized Computer Analyses for Licensing Evaluation, Version 5.0, ORNL/TM-2005/39, ORNL (2005).

SQAP, Software Quality Assurance Plan for SCALE 5.0 for Sun ${ }^{\circledR}$ Workstations, INL/INT-06-0011943, Rev. 0, Idaho National Laboratory, January 2007

TRTR-4, Specification for University of Missouri Fuel Elements Assembled for University of Missouri Research Reactor, Rev. 4, EG\&G Idaho Inc., Idaho Falls, ID, 1994.

TSUNAMI, B. T. Rearden, “TSUNAMI-3D: Control Module for Three-Dimensional Cross-Section Sensitivity and Uncertainty Analysis for Criticality", NUREG/CR-0200, Revision 7, Volume I, Section C9, ORNL/NUREG/CSD-2/V1/R7.

\subsection{Codes, Standards, Regulations, and Procedures}

ASM International, 1990, Properties and Selection: Nonferrous Alloys and Special-Purpose Materials, Volume 2 of ASM Handbook. Formerly Tenth Edition, Metals Handbook. 5th Printing 1998, [Materials Park, Ohio]: ASM International, TIC: 241059.

ASTM A 240/a240M-97a, Standard Specification for Chromium and Chromium-Nickel Stainless Steel Plate, Sheet, and Strip for Pressure Vessels and for General Applications, West Conshohocken, Pennsylvania: 1997.

ASTM A 276-91a, Standard Specification for Stainless Steel Bars and Shapes, West Conshohocken, Pennsylvania: 1991.

ASTM A 516/A 516M-90, Standard Specification for Pressure Vessel Plates, Carbon Steel, for Moderate- and Lower-Temperature Service, West Conshohocken, Pennsylvania: 1990.

ASTM B 932-04, 2004, Standard Specification for Low-Carbon Nickel-Chromium-MolybdenumGadolinium Alloy Plate, Sheet, and Strip, West Conshohocken, Pennsylvania: TIC: 255846.

ASTM G 1-90, (Reapproved 1999), Standard Practice for Preparing, Cleaning, and Evaluating Corrosion Test Specimens, West Conshohocken, Pennsylvania: 1999.

LP-SI.11Q-BSC, Rev. 0, ICN 1, Software Management, Washington, D.C.: U.S. Department of Energy, Office of Civilian Radioactive Waste Management, ACC: DOC.20041005.0008. 
NATIONAL SPENT NUCLEAR FUEL PROGRAM ENGINEERING DESIGN FILE

EDF-NSNF-068

Revision 0

Page 72 of 84

Title: Criticality Analysis for Proposed Maximum Fuel Loading in a Standardized SNF Canister with Type 1a Baskets

\section{Appendix A}

MCNP Code - Input files 
Revision 0

Page 73 of 84

Title: Criticality Analysis for Proposed Maximum Fuel Loading in a Standardized SNF Canister with Type 1a Baskets

\section{Appendix A}

\section{MCNP Code - Input files}

\begin{tabular}{lcc} 
input file name & date created & size bytes \\
& \multicolumn{2}{c}{ Directory Table $7.2-1$} \\
atr20 & $2 / 15 / 2007$ & 31,094 \\
atr20-nogd & $2 / 15 / 2007$ & 31,094 \\
atr30 & $2 / 15 / 2007$ & 31,231 \\
atr30-nogd & $2 / 15 / 2007$ & 31,229 \\
mit30 & $2 / 15 / 2007$ & 21,011 \\
mit30-nogd & $2 / 15 / 2007$ & 21,011 \\
mu24c & $2 / 15 / 2007$ & 28,409 \\
mu24c-nogd & $2 / 15 / 2007$ & 28,409 \\
orr30 & $2 / 15 / 2007$ & 23,712 \\
orr30-nogd & $2 / 15 / 2007$ & 23,712
\end{tabular}

Directory Table7.2-2

$\begin{array}{lll}\text { d1 cnba } & 2 / 15 / 2007 & 34,839 \\ \text { d1 cnbb+L } & 2 / 15 / 2007 & 35,022 \\ \text { m1a24c } & 2 / 15 / 2007 & 31,911 \\ \text { mit1d } & 2 / 15 / 2007 & 24,586 \\ \text { olbleu } & 2 / 15 / 2007 & 27,483\end{array}$

Directory Table 7.3.1-1

$\begin{array}{lll}\text { homa24c-w } & 2 / 15 / 2007 & 20,014 \\ \text { homa30-w } & 2 / 15 / 2007 & 20,223 \\ \text { homa_0-w } & 2 / 15 / 2007 & 20,090 \\ \text { mthom_0-w } & 2 / 15 / 2007 & 20,076 \\ \text { ohom_0-w } & 2 / 15 / 2007 & 20,080\end{array}$

Directory Table 7.3.2-1

homaV30_0-w
$2 / 15 / 2007 \quad 20,422$

$$
\begin{array}{rlr}
\text { input file name } & \begin{array}{l}
\text { date } \\
\text { created } \quad \text { size bytes } \\
\text { Directory Table7.3.3-1 }
\end{array}
\end{array}
$$

atr30-side-dropr $\quad 2 / 15 / 2007 \quad 30,827$

$\begin{array}{lll}\text { homaE_0 } & 2 / 15 / 2007 & 16,007 \\ \text { homaE_20 } & 2 / 15 / 2007 & 16,014 \\ \text { homaE_50 } & 2 / 15 / 2007 & 16,014\end{array}$

Directory Table 7.3.5-1

sph-mu2410 2/15/2007 $\quad 6,573$

sph_0 2/15/2007 6,632

Directory Table7.3.6-1

$\begin{array}{lll}\text { cyl_0+ca } & 2 / 15 / 2007 & 7,028 \\ \text { cy_0-mit } & 2 / 15 / 2007 & 6,951 \\ \text { cy_0-mu24 } & 2 / 15 / 2007 & 6,951 \\ \text { cy_0-orr } & 2 / 15 / 2007 & 6,977\end{array}$

Directory Table7.3.7-1

homa_fl+L $\quad 2 / 15 / 2007 \quad 20,958$

Directory Table7.4-1

$\begin{array}{lll}\text { m9cya_0 } & \text { 2/15/2007 } & 8,427 \\ \text { m9cya_10 } & 2 / 15 / 2007 & 8,048 \\ \text { m9cya_100 } & 2 / 15 / 2007 & 8,038 \\ \text { m9cymi_0 } & 2 / 15 / 2007 & 8,348\end{array}$


NATIONAL SPENT NUCLEAR FUEL PROGRAM ENGINEERING DESIGN FILE

EDF-NSNF-068

Revision 0

Page 74 of 84

\begin{tabular}{|c|c|c|c|c|c|}
\hline \multicolumn{6}{|c|}{$\begin{array}{l}\text { Title: Criticality Analysis for Proposed Maximum Fuel Loading in a Standardized SNF Canister with Type } \\
\text { 1a Baskets }\end{array}$} \\
\hline homaV_0-w & $2 / 15 / 2007$ & 20,084 & m9cymi_10 & $2 / 15 / 2007$ & 8,438 \\
\hline homV24_0-w & $2 / 15 / 2007$ & 19,625 & m9cymi_100 & $2 / 15 / 2007$ & 8,429 \\
\hline mthomV_0-w & $2 / 15 / 2007$ & 20,267 & m9cyo_0 & $2 / 15 / 2007$ & 8,375 \\
\hline \multirow[t]{4}{*}{ ohomV_0-w } & $2 / 15 / 2007$ & 20,272 & m9cyo_10 & $2 / 15 / 2007$ & 8,474 \\
\hline & & & m9cyo_100 & $2 / 15 / 2007$ & 8,465 \\
\hline & & & m9cy_0 & $2 / 15 / 2007$ & 8,348 \\
\hline & \multicolumn{2}{|c|}{ Directory Table 7.3.2-2 } & m9cy_10 & $2 / 15 / 2007$ & 8,447 \\
\hline homaV_0-w & $2 / 15 / 2007$ & 20,084 & m9cy_100 & $2 / 15 / 2007$ & 8,438 \\
\hline homaV_20-w & $2 / 15 / 2007$ & 20,024 & & & \\
\hline homaV_40-w & $2 / 15 / 2007$ & 20,024 & & & \\
\hline homaV_50-w & $2 / 15 / 2007$ & 20,017 & & \multicolumn{2}{|c|}{ Directory Table7.4-2 } \\
\hline homaV_60-w & $2 / 15 / 2007$ & 20,024 & csk7int_dwH & $2 / 15 / 2007$ & 29,160 \\
\hline homaV_75-w & $2 / 15 / 2007$ & 20,024 & csk7int_dwHSS & $2 / 15 / 2007$ & 29,160 \\
\hline \multirow[t]{4}{*}{ homaV_fl-w } & $2 / 15 / 2007$ & 20,507 & csk9int_dd & $2 / 15 / 2007$ & 29,378 \\
\hline & & & csk9int_dw & $2 / 15 / 2007$ & 29,378 \\
\hline & & & csk9int_dwSS & $2 / 15 / 2007$ & 29,378 \\
\hline & \multicolumn{2}{|c|}{ Directory Table7.3.2-3 } & csk9int_wd & $2 / 15 / 2007$ & 29,380 \\
\hline homV24_0-w & $2 / 15 / 2007$ & 19,625 & csk9int_ww & $2 / 15 / 2007$ & 29,573 \\
\hline homV24_20-w & $2 / 15 / 2007$ & 19,988 & csk9int_wwSS & $2 / 15 / 2007$ & 29,572 \\
\hline homV24_40-w & $2 / 15 / 2007$ & 19,988 & & & \\
\hline homV24_60-w & $2 / 15 / 2007$ & 19,988 & & & \\
\hline homV24_75-w & $2 / 15 / 2007$ & 19,988 & & & \\
\hline homV24_fll-w & $2 / 15 / 2007$ & 20,314 & & & \\
\hline
\end{tabular}


NATIONAL SPENT NUCLEAR FUEL PROGRAM ENGINEERING DESIGN FILE

EDF-NSNF-068

Revision 0

Page 75 of 84

Title: Criticality Analysis for Proposed Maximum Fuel Loading in a Standardized SNF Canister with Type 1a Baskets

\section{Appendix B}

\section{Fuels Identified for Loading in Type 1a Baskets}




\section{Appendix B}

\section{Fuels Identified for Loading in Type 1a Baskets}

The concept of the Type 1a basket developed out of planned loading of Advanced Test Reactor (ATR) fuels. The dimensions of the basket compartments lend themselves to many other fuels, not only within the aluminum fuel group, but also for several other fuels within the other eight fuel groups identified for criticality analysis for the repository.

The basket design is flexible in terms of being able to vary the basket lengths to deal with longer or shorter fuels, and then stacking the baskets to load a canister. The physical incorporation of gadolinium poisoning will be constant to the basket compartment plates regardless of the decreased fissile loads for these various fuels.

The selection of ATR as the baseline fuel for loading in the Type 1a basket bounds the total fissile in a canister $(32.55 \mathrm{~kg})$. This approach also provides a basis for linear loading $(78.62 \mathrm{~g} / \mathrm{cm})$ in a canister which should not be exceeded by any of the other fuels identified for loading in a Type la basket. A necessary condition for reconfiguring any fuel from existing storage into a disposal canister requires a criticality safety evaluation (CSE) prior to loading; this will generate an associated load map. Each CSE must evaluate both dry and flooded conditions for the as-loaded fuel, and demonstrate an acceptable reactivity that is less than the established subcritical limit. Preferably, the calculated reactivity should be shown to be lower than the baseline (ATR) fuel in a comparable configuration. This would allow foregoing any other criticality evaluations where the other parameters (total fissile mass, enrichment, canister linear loading, physical weight, and thermal output) are also below baseline values.

There is a small number of fuel types identified for installation in Type 1a baskets where at least one of the aforementioned parameters is in excess of the ATR fuel. As an example, the CP5 Converter Cylinders have a fissile linear loading per fuel assembly that is $106.4 \%$ of baseline, and a fissile atomdensity in the fuel element itself that is $499.3 \%$ of baseline. Inserting this fuel type into a canister results in a total fissile mass of $16.791 \mathrm{~kg}$, or $51.6 \%$ of baseline for a fully loaded canister. Similarly, the homogenous distribution of the fissile mass throughout the canister produces a calculated fissile atomdensity of only $83.3 \%$ of baseline fuel concentrations. However, there are only two pieces of this fuel for a total of less than $1.2 \mathrm{~kg}^{235} \mathrm{U}$. Similarly, a fully loaded canister with GA RERTR fuel might have raised a concern@97.8\% of ATR baseline atom-density in a canister were it not there is only one piece of that fuel with 381 grams of ${ }^{235} \mathrm{U}$. 
NATIONAL SPENT NUCLEAR FUEL PROGRAM ENGINEERING DESIGN FILE

EDF-NSNF-068

Revision 0

Page 77 of 84

Title: Criticality Analysis for Proposed Maximum Fuel Loading in a Standardized SNF Canister with Type 1a Baskets

Showing the calculated, homogenous distribution of fissile atom-densities in a loaded canister allows a relative comparison against the loaded canister with ATR fuel under near equivalent conditions, equating to maximum reactivity if the canister were to flood.

The fuels identified for loading in a Type 1a basket were all listed in the Table B-1 information as though there is enough of any one reactor specific fuel to fill a canister. Such is not always the case.

However, of the calculated fully-loaded canisters, none show a fissile atom-density in the loaded canister greater than $50 \%$ of ATR baseline values except for the three fuels (MURR, ORR, and MIT) selected for these analyses, and the two noted exceptions. This fact is important because the fissile mass for the loaded canisters shown in Table B-1 is based on the end-of-life values reported on the DOE 741 forms associated with all fuel transfers. Even if 50\% burnup were arbitrarily assigned to any of these other fuels, a fullyloaded canister at double the fissile mass would still have a fissile atom-density within the loaded canister that is less than the baseline ATR values. 
NATIONAL SPENT NUCLEAR FUEL PROGRAM ENGINEERING DESIGN FILE

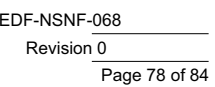

Table B-1 List of DOE fuels identified for disposal in a Type 1a basket configuration.

Fuel Category: UAlx Fissile/FHU baseline Fissile/ FHU $\begin{gathered}\% \text { of } \\ \text { baseline }\end{gathered}$ SNF can. $\begin{gathered}\text { SNF can. } \\ \text { Intrnl. Basket basket(s) / per }\end{gathered}$ fuel length fuel Intrnl. dia. Intrnl. design canister canis

ssile/canister baseline Linear baselin

\begin{tabular}{|c|c|c|c|c|c|c|c|c|c|c|c|c|c|c|c|c|c|}
\hline $\begin{array}{c}\text { Fuel Name [Fuel ID \#] } \\
\text { Baseline Fuel }\end{array}$ & (g) & $(\%)$ & $(\mathrm{g} / \mathrm{cm})$ & $(\%)$ & (cm) & (cm) & (type) & (\#) & (\#) & $(\mathrm{kg})$ & $(\%)$ & $(\mathrm{g} / \mathrm{cm})$ & $(\%)$ & $\underset{[\mathrm{atom} / \mathrm{b}-\mathrm{cm})}{\mathrm{b}}$ & $\begin{array}{c}\% \text { of } \\
\text { baseline fuel }\end{array}$ & $\begin{array}{l}\text { (atom/b-cm) } \\
\text { [per canister] }\end{array}$ & $\begin{array}{l}\% \text { of } \\
\text { baseline } \\
\text { fuel }\end{array}$ \\
\hline ATR (w/ poisoned basket) & 1085.00 & $100 \%$ & 8.62960 & $100.0 \%$ & 43.82 & 414.02 & Type 1a-3 & 3 & 30 & 32.550 & $100 \%$ & 78.6194 & $100 \%$ & $3.989 \mathrm{E}-04$ & $100 \%$ & $1.336 \mathrm{E}-04$ & $100 \%$ \\
\hline ANLJ [5] & 135.969 & $12.5 \%$ & 1.0569 & $12.2 \%$ & 43.82 & 256.50 & Type $1 \mathrm{a}-1$ & 1 & 10 & 1.360 & $4.2 \%$ & 5.3009 & $6.7 \%$ & $5.938 \mathrm{E}-05$ & $14.9 \%$ & $9.008 \mathrm{E}-06$ & $6.7 \%$ \\
\hline ARMF (PLATES) [8] & 12.130 & $1.1 \%$ & 0.1873 & $2.2 \%$ & 43.82 & 256.50 & Type 1a-3 & 3 & 30 & 0.364 & $1.1 \%$ & 1.4187 & $1.8 \%$ & $3.885 \mathrm{E}-04$ & $97.4 \%$ & 2.411E-06 & $1.8 \%$ \\
\hline ARMF/CFRMF MARK I [9] & 186.036 & $17.1 \%$ & 1.8841 & $21.8 \%$ & 43.82 & 256.50 & Type $1 \mathrm{a}-2$ & 2 & 20 & 3.721 & $11.4 \%$ & 14.5057 & $18.5 \%$ & $7.041 \mathrm{E}-05$ & $17.7 \%$ & $2.465 \mathrm{E}-05$ & $18.5 \%$ \\
\hline ARMF/CFRMF MARK I LL [10] & 110.000 & $10.1 \%$ & 1.1140 & $12.9 \%$ & 43.82 & 256.50 & Type $1 \mathrm{a}-2$ & 2 & 20 & 2.200 & $6.8 \%$ & 8.5770 & $10.9 \%$ & 4.159E-05 & $10.4 \%$ & 1.457E-05 & $10.9 \%$ \\
\hline ARMF/CFRMF MARK II [11] & 135.500 & $12.5 \%$ & 1.3723 & $15.9 \%$ & 43.82 & 256.50 & Type $1 \mathrm{a}-2$ & 2 & 20 & 2.710 & $8.3 \%$ & 10.5653 & $13.4 \%$ & $5.123 \mathrm{E}-05$ & $12.8 \%$ & 1.795E-05 & $13.4 \%$ \\
\hline ARMF/CFRMF MARK III [12] & 22.000 & $2.0 \%$ & 0.2228 & $2.6 \%$ & 43.82 & 256.50 & Type 1a-2 & 2 & 20 & 0.440 & $1.4 \%$ & 1.7154 & $2.2 \%$ & 8.317E-06 & $2.1 \%$ & 2.915E-06 & $2.2 \%$ \\
\hline ATR [15] & 683.479 & $63.0 \%$ & 5.4361 & $63.0 \%$ & 43.82 & 414.02 & Type $1 \mathrm{a}-2$ & 3 & 30 & 20.504 & $63.0 \%$ & 49.5251 & $63.0 \%$ & $2.022 \mathrm{E}-04$ & $50.7 \%$ & $8.416 \mathrm{E}-05$ & $63.0 \%$ \\
\hline ATR [16] & 750.530 & $69.2 \%$ & 4.4601 & $51.7 \%$ & 43.82 & 414.02 & Type 1a-3 & 3 & 30 & 22.516 & $69.2 \%$ & 54.3836 & $69.2 \%$ & $1.628 \mathrm{E}-04$ & $40.8 \%$ & $9.241 \mathrm{E}-05$ & $69.2 \%$ \\
\hline ATSR $[17]$ & 149.557 & $13.8 \%$ & 2.3187 & $26.9 \%$ & 43.82 & 256.50 & Type 1a-3 & 3 & 30 & 4.487 & $13.8 \%$ & 17.4920 & $22.2 \%$ & $9.520 \mathrm{E}-05$ & $23.9 \%$ & $2.972 \mathrm{E}-05$ & $22.2 \%$ \\
\hline BNL MEDICAL RX (BMRR) [21] & 111.911 & $10.3 \%$ & 1.7906 & $20.7 \%$ & 43.82 & 256.50 & Type $1 a-3$ & 3 & 30 & 3.357 & $10.3 \%$ & 13.0890 & $16.6 \%$ & 7.882E-05 & $19.8 \%$ & 2.224E-05 & $16.6 \%$ \\
\hline GTRR [87] & 161.408 & $14.9 \%$ & 2.3108 & $26.8 \%$ & 43.82 & 256.50 & Type $1 \mathrm{a}-3$ & 3 & 30 & 4.842 & $14.9 \%$ & 18.8781 & $24.0 \%$ & $1.118 \mathrm{E}-04$ & $28.0 \%$ & $3.208 \mathrm{E}-05$ & $24.0 \%$ \\
\hline GENTR [97] & 230.284 & $21.2 \%$ & 4.5332 & $52.5 \%$ & 43.82 & 256.50 & Type $1 \mathrm{a}-4$ & 4 & 40 & 9.211 & $28.3 \%$ & 35.9118 & $45.7 \%$ & 3.667E-04 & $91.9 \%$ & $6.102 \mathrm{E}-05$ & $45.7 \%$ \\
\hline JMTR (JAPAN) [123] & 217.072 & $20.0 \%$ & 2.7134 & $31.4 \%$ & 43.82 & 256.50 & Type $1 \mathrm{a}-2$ & 2 & 20 & 4.341 & $13.3 \%$ & 16.9257 & $21.5 \%$ & 1.171E-04 & $29.4 \%$ & 2.876E-05 & $21.5 \%$ \\
\hline MIT [135] & 346.483 & $31.9 \%$ & 5.1962 & $60.2 \%$ & 43.82 & 256.50 & Type 1a-3 & 3 & 30 & 10.394 & $31.9 \%$ & 40.5244 & $51.5 \%$ & $3.566 \mathrm{E}-04$ & $89.4 \%$ & $6.886 \mathrm{E}-05$ & $51.5 \%$ \\
\hline MIT [136] & 308.382 & $28.4 \%$ & 4.6248 & $53.6 \%$ & 43.82 & 256.50 & Type 1a-3 & 3 & 30 & 9.251 & $28.4 \%$ & 36.0681 & $45.9 \%$ & 3.174E-04 & $79.6 \%$ & $6.129 \mathrm{E}-05$ & $45.9 \%$ \\
\hline MURR (COLUMBIA) [142] & 593.895 & $54.7 \%$ & 7.1944 & $83.4 \%$ & 43.82 & 256.50 & Type 1a-3 & 3 & 24 & 14.253 & $43.8 \%$ & 55.5691 & $70.7 \%$ & $2.601 \mathrm{E}-04$ & $65.2 \%$ & $9.443 \mathrm{E}-05$ & $70.7 \%$ \\
\hline MURR (COLUMBIA) [143] & 595.016 & $54.8 \%$ & 6.8393 & $79.3 \%$ & 43.82 & 256.50 & Type $1 \mathrm{a}-3$ & 3 & 24 & 14.280 & $43.9 \%$ & 55.6740 & $70.8 \%$ & $2.684 \mathrm{E}-04$ & $67.3 \%$ & $9.460 \mathrm{E}-05$ & $70.8 \%$ \\
\hline UMRR (ROLLA) [146] & 186.000 & $17.1 \%$ & 2.1379 & $24.8 \%$ & 43.82 & 256.50 & Type $1 \mathrm{a}-2$ & 2 & 20 & 3.720 & $11.4 \%$ & 14.5029 & $18.4 \%$ & 8.279E-05 & $20.8 \%$ & 2.464E-05 & $18.4 \%$ \\
\hline OHIO STATE [157] & 132.483 & $12.2 \%$ & 2.0655 & $23.9 \%$ & 43.82 & 256.50 & Type 1a-3 & 3 & 30 & 3.975 & $12.2 \%$ & 15.4951 & $19.7 \%$ & $9.114 \mathrm{E}-05$ & $22.9 \%$ & 2.633E-05 & $19.7 \%$ \\
\hline OHIO STATE [158] & 172.290 & $15.9 \%$ & 1.9380 & $22.5 \%$ & 43.82 & 256.50 & Type 1a-2 & 2 & 20 & 3.446 & $10.6 \%$ & 13.4339 & $17.1 \%$ & $8.552 \mathrm{E}-05$ & $21.4 \%$ & $2.283 \mathrm{E}-05$ & $17.1 \%$ \\
\hline ORR [165] & 260.789 & $24.0 \%$ & 4.0558 & $47.0 \%$ & 43.82 & 256.50 & Type 1a-3 & 3 & 30 & 7.824 & $24.0 \%$ & 30.5016 & $38.8 \%$ & $1.694 \mathrm{E}-04$ & $42.5 \%$ & $5.183 \mathrm{E}-05$ & $38.8 \%$ \\
\hline PURDUE UNIVERSITY [177] & 16.500 & $1.5 \%$ & 0.2014 & $2.3 \%$ & 43.82 & 256.50 & Type $1 \mathrm{a}-2$ & 2 & 20 & 0.330 & $1.0 \%$ & 1.2865 & $1.6 \%$ & 4.459E-04 & $111.8 \%$ & $2.186 \mathrm{E}-06$ & $1.6 \%$ \\
\hline PURDUE UNIVERSITY [178] & 215.910 & $19.9 \%$ & 2.6356 & $30.5 \%$ & 43.82 & 256.50 & Type $1 \mathrm{a}-2$ & 2 & 20 & 4.318 & $13.3 \%$ & 16.8351 & $21.4 \%$ & 1.194E-04 & $29.9 \%$ & $2.861 \mathrm{E}-05$ & $21.4 \%$ \\
\hline RINSC [180] & 109.955 & $10.1 \%$ & 1.7593 & $20.4 \%$ & 43.82 & 256.50 & Type $1 \mathrm{a}-3$ & 3 & 30 & 3.299 & $10.1 \%$ & 12.8603 & $16.4 \%$ & 7.763E-05 & $19.5 \%$ & $2.185 \mathrm{E}-05$ & $16.4 \%$ \\
\hline RINSC [181] & 259.611 & $23.9 \%$ & 2.5552 & $29.6 \%$ & 43.82 & 256.50 & Type $1 \mathrm{a}-2$ & 2 & 20 & 5.192 & $16.0 \%$ & 20.2426 & $25.7 \%$ & 1.128E-04 & $28.3 \%$ & $3.440 \mathrm{E}-05$ & $25.7 \%$ \\
\hline
\end{tabular}


NATIONAL SPENT NUCLEAR FUEL PROGRAM ENGINEERING DESIGN FILE

EDF-NSNF-068

Revision 0

Page 79 of 84

Title: Criticality Analysis for Proposed Maximum Fuel Loading in a Standardized SNF Canister with Type
1a Baskets

\begin{tabular}{|c|c|c|c|c|c|c|c|c|}
\hline $\begin{array}{l}\text { UNIV OF FLORIDA (ARGONAUT) } \\
{[272]}\end{array}$ & 14.707 & $1.4 \%$ & 0.2135 & $2.5 \%$ & 43.82 & 256.50 & Type $1 \mathrm{a}-3$ & 3 \\
\hline $\begin{array}{l}\text { UNIV OF FLORIDA (ARGONAUT) } \\
\text { [273] }\end{array}$ & 14.109 & $1.3 \%$ & 0.2048 & $2.4 \%$ & 43.82 & 256.50 & Type $1 \mathrm{a}-3$ & 3 \\
\hline UNIV OF MASS-LOWELL [274] & 122.677 & $11.3 \%$ & 1.9319 & $22.4 \%$ & 43.82 & 256.50 & Type $1 \mathrm{a}-3$ & 3 \\
\hline UNIV OF MASS-LOWELL [275] & 68.870 & $6.3 \%$ & 1.0846 & $12.6 \%$ & 43.82 & 256.50 & Type $1 \mathrm{a}-3$ & 3 \\
\hline UNIV OF MICHIGAN [276] & 93.925 & $8.7 \%$ & 1.0749 & $12.5 \%$ & 43.82 & 256.50 & Type $1 \mathrm{a}-2$ & 2 \\
\hline UNIV OF MICHIGAN [277] & 122.159 & $11.3 \%$ & 1.2698 & $14.7 \%$ & 43.82 & 256.50 & Type $1 \mathrm{a}-2$ & 2 \\
\hline UNIV OF VIRGINIA [279] & 137.895 & $12.7 \%$ & 1.5794 & $18.3 \%$ & 43.82 & 256.50 & Type $1 \mathrm{a}-2$ & 2 \\
\hline $\begin{array}{l}\text { WORCESTER POLY INSTITUTE } \\
\text { [287] }\end{array}$ & 173.000 & $15.9 \%$ & 2.7244 & $31.6 \%$ & 43.82 & 256.50 & Type 1a-3 & 3 \\
\hline [287] & 85.059 & $7.8 \%$ & 0.9666 & $11.2 \%$ & 43.82 & 256.50 & Type $1 \mathrm{a}-2$ & 2 \\
\hline FRR TUBES (DENMARK) [298] & 77.400 & $7.1 \%$ & 1.2384 & $14.4 \%$ & 43.82 & 256.50 & Type $1 \mathrm{a}-3$ & 3 \\
\hline FRR TUBES (AUSTRALIA) [299] & 100.000 & $9.2 \%$ & 1.6000 & $18.5 \%$ & 43.82 & 256.50 & Type $1 \mathrm{a}-3$ & 3 \\
\hline FRR TUBES (AUSTRALIA) [300] & 54.049 & $5.0 \%$ & 0.8648 & $10.0 \%$ & 43.82 & 256.50 & Type $1 \mathrm{a}-3$ & 3 \\
\hline GRR (GREECE) [440] & 114.823 & $10.6 \%$ & 1.4759 & $17.1 \%$ & 43.82 & 256.50 & Type $1 \mathrm{a}-3$ & 3 \\
\hline SAPHIR (SWITZERLAND) [443] & 218.743 & $20.2 \%$ & 2.4999 & $29.0 \%$ & 43.82 & 256.50 & Type 1a-2 & 2 \\
\hline SAPHIR (SWITZERLAND) [444] & 103.504 & $9.5 \%$ & 1.1829 & $13.7 \%$ & 43.82 & 256.50 & Type $1 \mathrm{a}-2$ & 2 \\
\hline JRR-4 (JAPAN) [505] & 131.348 & $12.1 \%$ & 1.9781 & $22.9 \%$ & 43.82 & 256.50 & Type $1 \mathrm{a}-3$ & 3 \\
\hline FRR MTR-S (JAPAN) [506] & 165.900 & $15.3 \%$ & 1.8852 & $21.8 \%$ & 43.82 & 256.50 & Type $1 \mathrm{a}-2$ & 2 \\
\hline JMTR (JAPAN) [507] & 287.000 & $26.5 \%$ & 3.2614 & $37.8 \%$ & 43.82 & 256.50 & Type $1 \mathrm{a}-2$ & 2 \\
\hline FRR MTR-S (JAPAN) [508] & 193.200 & $17.8 \%$ & 2.1955 & $25.4 \%$ & 43.82 & 256.50 & Type $1 \mathrm{a}-2$ & 2 \\
\hline FRR MTR-C (NETHERLANDS) [509] & 63.200 & $5.8 \%$ & 0.7182 & $8.3 \%$ & 43.82 & 256.50 & Type $1 \mathrm{a}-2$ & 2 \\
\hline FRR MTR-S (NETHERLANDS) [510] & 120.000 & $11.1 \%$ & 1.3636 & $15.8 \%$ & 43.82 & 256.50 & Type $1 \mathrm{a}-2$ & 2 \\
\hline FRR MTR-C (CANADA) [512] & 81.500 & $7.5 \%$ & 0.9261 & $10.7 \%$ & 43.82 & 256.50 & Type $1 \mathrm{a}-2$ & 2 \\
\hline FRR MTR-S (CANADA) [513] & 145.000 & $13.4 \%$ & 1.6477 & $19.1 \%$ & 43.82 & 256.50 & Type $1 \mathrm{a}-2$ & 2 \\
\hline FRR ASTRA (AUSTRIA) [515] & 122.500 & $11.3 \%$ & 1.4032 & $16.3 \%$ & 43.82 & 256.50 & Type $1 \mathrm{a}-2$ & 2 \\
\hline FRR MTR-C (GERMANY) [517] & 52.360 & $4.8 \%$ & 0.5950 & $6.9 \%$ & 43.82 & 256.50 & Type $1 \mathrm{a}-2$ & 2 \\
\hline FRR MTR-S (GERMANY) [519] & 70.840 & $6.5 \%$ & 0.8050 & $9.3 \%$ & 43.82 & 256.50 & Type $1 \mathrm{a}-2$ & 2 \\
\hline FRR MTR-C (SWEDEN) [523] & 149.606 & $13.8 \%$ & 1.7001 & $19.7 \%$ & 43.82 & 256.50 & Type $1 \mathrm{a}-2$ & 2 \\
\hline FRR MTR-C2 (TURKEY) [527] & 124.000 & $11.4 \%$ & 1.4091 & $16.3 \%$ & 43.82 & 256.50 & Type $1 \mathrm{a}-2$ & 2 \\
\hline FRR MTR-S (TURKEY) [528] & 168.000 & $15.5 \%$ & 1.9091 & $22.1 \%$ & 43.82 & 256.50 & Type $1 a-2$ & 2 \\
\hline FRR MTR-C (GREECE) [531] & 79.950 & $7.4 \%$ & 0.9085 & $10.5 \%$ & 43.82 & 256.50 & Type 1a-2 & 2 \\
\hline FRR MTR-S (GREECE) [532] & 144.300 & $13.3 \%$ & 1.6398 & $19.0 \%$ & 43.82 & 256.50 & Type $1 \mathrm{a}-2$ & 2 \\
\hline FRR MTR-C (PORTUGAL) [540] & 74.700 & $6.9 \%$ & 0.7863 & $9.1 \%$ & 43.82 & 256.50 & Type $1 \mathrm{a}-2$ & 2 \\
\hline FRR MTR-O (PORTUGAL) [541] & 80.000 & $7.4 \%$ & 0.8421 & $9.8 \%$ & 43.82 & 256.50 & Type $1 \mathrm{a}-2$ & 2 \\
\hline FRR MTR-S (PORTUGAL) [542] & 138.600 & $12.8 \%$ & 1.4589 & $16.9 \%$ & 43.82 & 256.50 & Type $1 \mathrm{a}-2$ & 2 \\
\hline IEA-R1 (BRAZIL) [545] & 131.078 & $12.1 \%$ & 1.5015 & $17.4 \%$ & 43.82 & 256.50 & Type $1 \mathrm{a}-2$ & 2 \\
\hline FRR MTR (ARGENTINA) [547] & 123.750 & $11.4 \%$ & 1.3026 & $15.1 \%$ & 43.82 & 256.50 & Type $1 \mathrm{a}-2$ & 2 \\
\hline FRR MTR (JAPAN) [551] & 128.982 & $11.9 \%$ & 1.3577 & $15.7 \%$ & 43.82 & 256.50 & Type $1 \mathrm{a}-2$ & 2 \\
\hline FRR MTR-C (JAPAN) [552] & 95.000 & $8.8 \%$ & 1.0000 & $11.6 \%$ & 43.82 & 256.50 & Type $1 \mathrm{a}-2$ & 2 \\
\hline FRR MTR-S (JAPAN) [553] & 147.636 & $13.6 \%$ & 1.5541 & $18.0 \%$ & 43.82 & 256.50 & Type $1 \mathrm{a}-2$ & 2 \\
\hline ZPRL (TAIWAN) [554] & 121.312 & $11.2 \%$ & 1.4582 & $16.9 \%$ & 43.82 & 256.50 & Type $1 \mathrm{a}-2$ & 2 \\
\hline FRR MTR (TAIWAN) [555] & 300.000 & $27.6 \%$ & 3.1579 & $36.6 \%$ & 43.82 & 256.50 & Type $1 \mathrm{a}-2$ & 2 \\
\hline
\end{tabular}

$\begin{array}{rrrlrr}0.441 & 1.4 \% & 1.7201 & 2.2 \% & 1.390 \mathrm{E}-05 & 3.5 \% \\ 0.423 & 1.3 \% & 1.6502 & 2.1 \% & 1.334 \mathrm{E}-05 & 3.3 \% \\ 3.680 & 11.3 \% & 14.3481 & 18.3 \% & 8.525 \mathrm{E}-05 & 21.4 \% \\ 2.066 & 6.3 \% & 8.0550 & 10.2 \% & 4.786 \mathrm{E}-05 & 12.0 \% \\ 1.879 & 5.8 \% & 7.3236 & 9.3 \% & 4.463 \mathrm{E}-05 & 11.2 \% \\ 2.443 & 7.5 \% & 9.5250 & 12.1 \% & 5.273 \mathrm{E}-05 & 13.2 \% \\ 2.758 & 8.5 \% & 10.7520 & 13.7 \% & 6.441 \mathrm{E}-05 & 16.1 \% \\ & & & & & \\ 5.190 & 15.9 \% & 20.2339 & 25.7 \% & 1.390 \mathrm{E}-04 & 34.8 \% \\ 1.701 & 5.2 \% & 6.6323 & 8.4 \% & 4.273 \mathrm{E}-05 & 10.7 \% \\ 2.322 & 7.1 \% & 9.0526 & 11.5 \% & 3.808 \mathrm{E}-05 & 9.5 \% \\ 3.000 & 9.2 \% & 11.6959 & 14.9 \% & 4.920 \mathrm{E}-05 & 12.3 \% \\ 1.621 & 5.0 \% & 6.3215 & 8.0 \% & 2.659 \mathrm{E}-05 & 6.7 \% \\ 3.445 & 10.6 \% & 13.4296 & 17.1 \% & 9.872 \mathrm{E}-05 & 24.8 \% \\ 4.375 & 13.4 \% & 17.0560 & 21.7 \% & 1.044 \mathrm{E}-04 & 26.2 \% \\ 2.070 & 6.4 \% & 8.0705 & 10.3 \% & 4.661 \mathrm{E}-05 & 11.7 \% \\ 3.940 & 12.1 \% & 15.3624 & 19.5 \% & 6.599 \mathrm{E}-05 & 16.5 \% \\ 3.318 & 10.2 \% & 12.9357 & 16.5 \% & 8.334 \mathrm{E}-05 & 20.9 \% \\ 5.740 & 17.6 \% & 22.3782 & 28.5 \% & 1.442 \mathrm{E}-04 & 36.1 \% \\ 3.864 & 11.9 \% & 15.0643 & 19.2 \% & 9.706 \mathrm{E}-05 & 24.3 \% \\ 1.264 & 3.9 \% & 4.9279 & 6.3 \% & 3.175 \mathrm{E}-05 & 8.0 \% \\ 2.400 & 7.4 \% & 9.3567 & 11.9 \% & 6.029 \mathrm{E}-05 & 15.1 \% \\ 1.630 & 5.0 \% & 6.3548 & 8.1 \% & 4.094 \mathrm{E}-05 & 10.3 \% \\ 2.900 & 8.9 \% & 11.3060 & 14.4 \% & 7.284 \mathrm{E}-05 & 18.3 \% \\ 2.450 & 7.5 \% & 9.5517 & 12.1 \% & 5.869 \mathrm{E}-05 & 14.7 \% \\ 1.047 & 3.2 \% & 4.0827 & 5.2 \% & 2.630 \mathrm{E}-05 & 6.6 \% \\ 1.417 & 4.4 \% & 5.5236 & 7.0 \% & 3.559 \mathrm{E}-05 & 8.9 \% \\ 2.992 & 9.2 \% & 11.6652 & 14.8 \% & 7.516 \mathrm{E}-05 & 18.8 \% \\ 2.480 & 7.6 \% & 9.6686 & 12.3 \% & 6.229 \mathrm{E}-05 & 15.6 \% \\ 3.360 & 10.3 \% & 13.0994 & 16.7 \% & 8.440 \mathrm{E}-05 & 21.2 \% \\ 1.599 & 4.9 \% & 6.2339 & 7.9 \% & 4.017 \mathrm{E}-05 & 10.1 \% \\ 2.886 & 8.9 \% & 11.2515 & 14.3 \% & 7.249 \mathrm{E}-05 & 18.2 \% \\ 1.494 & 4.6 \% & 5.8246 & 7.4 \% & 1.077 \mathrm{E}-04 & 27.0 \% \\ 1.600 & 4.9 \% & 6.2378 & 7.9 \% & 1.230 \mathrm{E}-04 & 30.8 \% \\ 2.772 & 8.5 \% & 10.8070 & 13.7 \% & 1.065 \mathrm{E}-04 & 26.7 \% \\ 2.622 & 8.1 \% & 10.2205 & 13.0 \% & 6.099 \mathrm{E}-05 & 15.3 \% \\ 2.475 & 7.6 \% & 9.6491 & 12.3 \% & 5.748 \mathrm{E}-05 & 14.4 \% \\ 2.580 & 7.9 \% & 10.0571 & 12.8 \% & 1.332 \mathrm{E}-04 & 33.4 \% \\ 1.900 & 5.8 \% & 7.4074 & 9.4 \% & 6.944 \mathrm{E}-05 & 17.4 \% \\ 2.953 & 9.1 \% & 11.5116 & 14.6 \% & 6.828 \mathrm{E}-05 & 17.1 \% \\ 2.426 & 7.5 \% & 9.4590 & 12.0 \% & 6.253 \mathrm{E}-05 & 15.7 \% \\ 6.000 & 18.4 \% & 23.3918 & 29.8 \% & 1.392 \mathrm{E}-04 & 34.9 \% \\ & & & & & \\ & & & & & \end{array}$

$2.923 \mathrm{E}-06 \quad 2.2 \%$

$2.804 \mathrm{E}-06 \quad 2.1 \%$ $2.438 \mathrm{E}-05 \quad 18.3 \%$ $1.369 \mathrm{E}-05 \quad 10.2 \%$ $1.244 \mathrm{E}-05 \quad 9.3 \%$ $1.619 \mathrm{E}-05 \quad 12.1 \%$ $1.827 \mathrm{E}-05 \quad 13.7 \%$

$3.438 \mathrm{E}-05 \quad 25.7 \%$ $1.127 \mathrm{E}-05 \quad 8.4 \%$ $1.538 \mathrm{E}-05 \quad 11.5 \%$ $1.987 \mathrm{E}-05 \quad 14.9 \%$ $1.074 \mathrm{E}-05 \quad 8.0 \%$ $2.282 \mathrm{E}-05 \quad 17.1 \%$ $2.898 \mathrm{E}-05 \quad 21.7 \%$ $1.371 \mathrm{E}-05 \quad 10.3 \%$ 2.610E-05 19.5\% $2.198 \mathrm{E}-05 \quad 16.5 \%$ $3.803 \mathrm{E}-05 \quad 28.5 \%$ 3.803E-05 28.5\% 2.560E-05 $19.2 \%$ $\begin{array}{ll}8.374 \mathrm{E}-06 & 6.3 \% \\ 1.590 \mathrm{E}-05 & 11.9 \%\end{array}$ $1.590 \mathrm{E}-05 \quad 11.9 \%$ $1.080 \mathrm{E}-05 \quad 8.1 \%$ $1.921 \mathrm{E}-05 \quad 14.4 \%$ $1.623 \mathrm{E}-05 \quad 12.1 \%$ $6.937 \mathrm{E}-06 \quad 5.2 \%$ 9.386E-06 $\quad 7.0 \%$ $1.982 \mathrm{E}-05 \quad 14.8 \%$ $1.643 \mathrm{E}-05 \quad 12.3 \%$ $2.226 \mathrm{E}-05 \quad 16.7 \%$ $1.059 \mathrm{E}-05 \quad 7.9 \%$ $1.912 \mathrm{E}-05 \quad 14.3 \%$ 9.897E-06 $\quad 7.4 \%$ $1.060 \mathrm{E}-05 \quad 7.9 \%$ $1.836 \mathrm{E}-05 \quad 13.7 \%$ $\begin{array}{ll}1.836 \mathrm{E}-05 & 13.7 \% \\ 1.737 \mathrm{E}-05 & 13.0 \%\end{array}$ $1.737 \mathrm{E}-05 \quad 13.0 \%$ $1.640 \mathrm{E}-05 \quad 12.3 \%$ $1.709 \mathrm{E}-05 \quad 12.8 \%$ $\begin{array}{ll}1.259 \mathrm{E}-05 & 9.4 \% \\ 1.956 \mathrm{E}-05 & 14.6 \%\end{array}$ $1.956 \mathrm{E}-05 \quad 14.6 \%$ $\begin{array}{ll}1.607 \mathrm{E}-05 & 12.0 \% \\ 3.975 \mathrm{E}-05 & 29.8 \%\end{array}$ 
NATIONAL SPENT NUCLEAR FUEL PROGRAM ENGINEERING DESIGN FILE

EDF-NSNF-068

Revision 0

Page 80 of 84

Title: Criticality Analysis for Proposed Maximum Fuel Loading in a Standardized SNF Canister with Type
1a Baskets

\begin{tabular}{|c|c|c|c|c|c|c|c|}
\hline RU-1 (URAGUAY) [557] & 104.480 & $9.6 \%$ & 1.2796 & $14.8 \%$ & 43.82 & 256.50 & Type 1a-2 \\
\hline PRR-1 (PHILLIPPINES) [558] & 114.902 & $10.6 \%$ & 1.1456 & $13.3 \%$ & 43.82 & 256.50 & Type 1a-2 \\
\hline FRR MTR (VENEZUELA) [559] & 101.688 & $9.4 \%$ & 1.0704 & $12.4 \%$ & 43.82 & 256.50 & Type 1a-2 \\
\hline FRR MTR (JAPAN) [565] & 322.677 & $29.7 \%$ & 3.3966 & $39.4 \%$ & 43.82 & 256.50 & Type $1 \mathrm{a}-2$ \\
\hline ASTRA (AUSTRIA) [566] & 121.590 & $11.2 \%$ & 1.7712 & $20.5 \%$ & 43.82 & 256.50 & Type 1a-3 \\
\hline ENEA SALUGGIA (ITALY) [574] & 127.725 & $11.8 \%$ & 1.9500 & $22.6 \%$ & 43.82 & 256.50 & Type 1a-3 \\
\hline FMRB (GERMANY) [577] & 111.339 & $10.3 \%$ & 1.1720 & $13.6 \%$ & 43.82 & 256.50 & Type 1a-2 \\
\hline =RR MTR-C (GERMANY) [579] & 55.460 & $5.1 \%$ & 0.5838 & $6.8 \%$ & 43.82 & 256.50 & Type $1 \mathrm{a}-2$ \\
\hline FRR MTR-S (GERMANY) [582] & 113.160 & $10.4 \%$ & 1.1912 & $13.8 \%$ & 43.82 & 256.50 & Type 1a-2 \\
\hline FRR MTR-S (GERMANY) [584] & 122.120 & $11.3 \%$ & 1.2855 & $14.9 \%$ & 43.82 & 256.50 & Type 1a-2 \\
\hline FRR MTR-S (GERMANY) [585] & 79.200 & $7.3 \%$ & 0.8337 & $9.7 \%$ & 43.82 & 256.50 & Type 1a-2 \\
\hline FRR MTR-S (GERMANY) [588] & 116.480 & $10.7 \%$ & 1.2261 & $14.2 \%$ & 43.82 & 256.50 & Type 1a-2 \\
\hline IAN-R1 (COLUMBIA) [596] & 136.776 & $12.6 \%$ & 1.4397 & $16.7 \%$ & 43.82 & 256.50 & Type 1a-2 \\
\hline FRR MTR-C (JAPAN) [600] & 70.228 & $6.5 \%$ & 0.7392 & $8.6 \%$ & 43.82 & 256.50 & Type 1a-2 \\
\hline KURR (JAPAN) [601] & 122.201 & $11.3 \%$ & 1.5974 & $18.5 \%$ & 43.82 & 256.50 & Type 1a-3 \\
\hline FRR MTR-S (JAPAN) [602] & 136.800 & $12.6 \%$ & 1.4400 & $16.7 \%$ & 43.82 & 256.50 & Type 1a-2 \\
\hline FRR MTR (JAPAN) [605] & 284.715 & $26.2 \%$ & 2.9970 & $34.7 \%$ & 43.82 & 256.50 & Type 1a-2 \\
\hline JRR-2 (JAPAN) [606] & 130.379 & $12.0 \%$ & 1.9635 & $22.8 \%$ & 43.82 & 256.50 & Type 1a-3 \\
\hline FRR MTR-S (NETHERLANDS) [607] & 50.000 & $4.6 \%$ & 0.5263 & $6.1 \%$ & 43.82 & 256.50 & Type 1a-2 \\
\hline FRR MTR-S (NETHERLANDS) [608] & 95.000 & $8.8 \%$ & 1.0000 & $11.6 \%$ & 43.82 & 256.50 & Type 1a-2 \\
\hline FRR MTR (NETHERLANDS) [609] & 211.788 & $19.5 \%$ & 2.2293 & $25.8 \%$ & 43.82 & 256.50 & Type 1a-2 \\
\hline FRR MTR-C (CANADA) [612] & 68.200 & $6.3 \%$ & 0.7179 & $8.3 \%$ & 43.82 & 256.50 & Type 1a-2 \\
\hline MACMASTER (CANADA) [614] & 100.211 & $9.2 \%$ & 1.4802 & $17.2 \%$ & 43.82 & 256.50 & Type 1a-3 \\
\hline FRR MTR (TAIWAN) [628] & 126.720 & $11.7 \%$ & 1.3339 & $15.5 \%$ & 43.82 & 256.50 & Type 1a-2 \\
\hline THOR (TAIWAN) [629] & 102.477 & $9.4 \%$ & 1.0214 & $11.8 \%$ & 43.82 & 256.50 & Type 1a-2 \\
\hline FRR MTR-C (PORTUGAL) [631] & 88.200 & $8.1 \%$ & 0.9284 & $10.8 \%$ & 43.82 & 256.50 & Type $1 \mathrm{a}-2$ \\
\hline FRR MTR-S (PORTUGAL) [632] & 158.400 & $14.6 \%$ & 1.6674 & $19.3 \%$ & 43.82 & 256.50 & Type 1a-2 \\
\hline TRR-1 (THAILAND) [633] & 133.754 & $12.3 \%$ & 1.5374 & $17.8 \%$ & 43.82 & 256.50 & Type $1 \mathrm{a}-2$ \\
\hline RA-3 (ARGENTINA) [634] & 118.399 & $10.9 \%$ & 1.3454 & $15.6 \%$ & 43.82 & 256.50 & Type 1a-2 \\
\hline$=$ RR MTR-C (ARGENTINA) [635] & 107.800 & $9.9 \%$ & 1.1347 & $13.1 \%$ & 43.82 & 256.50 & Type 1a-2 \\
\hline RA-3 (ARGENTINA) [636] & 119.103 & $11.0 \%$ & 1.3534 & $15.7 \%$ & 43.82 & 256.50 & Type $1 \mathrm{a}-2$ \\
\hline RRR-1 (PHILIPPIINES) [638] & 144.467 & $13.3 \%$ & 1.4341 & $16.6 \%$ & 43.82 & 256.50 & Type 1a-2 \\
\hline FRR MTR-O (TURKEY) [642] & 85.000 & $7.8 \%$ & 0.8947 & $10.4 \%$ & 43.82 & 256.50 & Type $1 \mathrm{a}-2$ \\
\hline FRR MTR-C (TURKEY) [643] & 103.500 & $9.5 \%$ & 1.0895 & $12.6 \%$ & 43.82 & 256.50 & Type $1 \mathrm{a}-2$ \\
\hline FRR MTR-S (TURKEY) [644] & 140.000 & $12.9 \%$ & 1.4737 & $17.1 \%$ & 43.82 & 256.50 & Type $1 \mathrm{a}-2$ \\
\hline ASTRA (AUSTRIA) [646] & 88.783 & $8.2 \%$ & 1.2933 & $15.0 \%$ & 43.82 & 256.50 & Type 1a-3 \\
\hline FRR MTR (AUSTRALIA) [649] & 248.751 & $22.9 \%$ & 2.8267 & $32.8 \%$ & 43.82 & 256.50 & Type $1 \mathrm{a}-2$ \\
\hline FRR ASTRA (AUSTRIA) [654] & 50.000 & $4.6 \%$ & 0.5263 & $6.1 \%$ & 43.82 & 256.50 & Type 1a-2 \\
\hline =RR MTR-C1 (SWITZERLAND) [656] & 61.280 & $5.6 \%$ & 0.6451 & $7.5 \%$ & 43.82 & 256.50 & Type 1a-2 \\
\hline =RR MTR-C2 (SWITZERLAND) [657] & 74.880 & $6.9 \%$ & 0.7882 & $9.1 \%$ & 43.82 & 256.50 & Type 1a-2 \\
\hline =RR MTR-S (SWITZERLAND) [658] & 87.420 & $8.1 \%$ & 0.9202 & $10.7 \%$ & 43.82 & 256.50 & Type $1 \mathrm{a}-2$ \\
\hline =RR PIN CLUSTER (CANADA) [663] & 207.100 & $19.1 \%$ & 0.6768 & $7.8 \%$ & 43.82 & 414.02 & Type 1a-1 \\
\hline RR TUBES (GERMANY) [673] & 90.000 & $8.3 \%$ & 1.4400 & $16.7 \%$ & 43.82 & 256.50 & Type 1a-3 \\
\hline ERR TUBES (GERMANY) [674] & 100.000 & $9.2 \%$ & 1.6000 & $18.5 \%$ & 43.82 & 256.50 & Type 1a-3 \\
\hline
\end{tabular}

$5.828 \mathrm{E}-05 \quad 14.6 \%$ 4.907E-05 $12.3 \%$ $1.046 \mathrm{E}-04 \quad 26.2 \%$ $1.386 \mathrm{E}-04 \quad 34.7 \%$ 7.398E-05 $18.5 \%$ $8.165 \mathrm{E}-05 \quad 20.5 \%$ $2.173 \mathrm{E}-04 \quad 54.5 \%$ $2.576 \mathrm{E}-05 \quad 6.5 \%$ $2.576 \mathrm{E}-05 \quad 6.5 \%$ $5.256 \mathrm{E}-05 \quad 13.2 \%$ $5.672 \mathrm{E}-05 \quad 14.2 \%$ $3.679 E-05 \quad 9.2 \%$ $5.410 \mathrm{E}-05 \quad 13.6 \%$ $2.103 \mathrm{E}-04 \quad 52.7 \%$ $1.080 \mathrm{E}-04 \quad 27.1 \%$ $\begin{array}{ll}6.668 \mathrm{E}-05 & 16.7 \% \\ 1.054 \mathrm{E}-04 & 26.4 \%\end{array}$ $\begin{array}{ll}1.054 \mathrm{E}-04 & 26.4 \% \\ 1.385 \mathrm{E}-04 & 34.7 \%\end{array}$ $\begin{array}{ll}1.385 \mathrm{E}-04 & 34.7 \% \\ 8.664 \mathrm{E}-05 & 21.7 \%\end{array}$ $8.664 \mathrm{E}-05 \quad 21.7 \%$ $6.954 \mathrm{E}-05 \quad 17.4 \%$ 6.933E-05 $\quad 17.4 \%$ 1.381E-04 $34.6 \%$ $3.168 \mathrm{E}-05 \quad 7.9 \%$ 6.055E-05 $15.2 \%$ $\begin{array}{ll}1.386 \mathrm{E}-04 & 34.7 \% \\ 4.391 \mathrm{E}-05 & 11.0 \%\end{array}$ $\begin{array}{ll}4.391 E-05 & 11.0 \% \\ 8.136 E-05 & 20.4 \%\end{array}$ 8.136E-05 $20.4 \%$ 8.344E-05 $20.9 \%$ $\begin{array}{ll}6.471 \mathrm{E}-05 & 16.2 \% \\ 5.386 \mathrm{E}-05 & 13.5 \%\end{array}$ $5.386 \mathrm{E}-05 \quad 13.5 \%$ $5.007 \mathrm{E}-05 \quad 12.6 \%$ $\begin{array}{ll}5.418 \mathrm{E}-05 & 13.6 \% \\ 6.170 \mathrm{E}-05 & 15.5 \%\end{array}$ $\begin{array}{ll}6.170 \mathrm{E}-05 & 15.5 \% \\ 6.222 \mathrm{E}-05 & 15.6 \%\end{array}$ $\begin{array}{ll}6.222 \mathrm{E}-05 & 15.6 \% \\ 6.630 \mathrm{E}-05 & 16.6 \%\end{array}$ $6.630 \mathrm{E}-05 \quad 16.6 \%$ $6.943 \mathrm{E}-05 \quad 17.4 \%$ $5.409 \mathrm{E}-05 \quad 13.6 \%$ $1.250 \mathrm{E}-04 \quad 31.3 \%$ 2.322E-05 $5.8 \%$ $4.779 \mathrm{E}-05 \quad 12.0 \%$ $4.796 \mathrm{E}-05$
$3.788 \mathrm{E}-05$ $1.844 \mathrm{E}-04 \quad 46.2 \%$ $\begin{array}{ll}1.844 E-04 & 46.2 \% \\ 4.434 E-05 & 11.1 \%\end{array}$ $\begin{array}{ll}4.434 \mathrm{E}-05 & 11.1 \% \\ 4.927 \mathrm{E}-05 & 12.4 \%\end{array}$
1.384E-05 $10.4 \%$ 1.522E-05 $11.4 \%$ $1.347 \mathrm{E}-05 \quad 10.1 \%$ 4.275E-05 $32.0 \%$ $2.417 \mathrm{E}-05 \quad 18.1 \%$ $2.538 \mathrm{E}-05 \quad 19.0 \%$ $1.475 \mathrm{E}-05 \quad 11.0 \%$ $7.348 \mathrm{E}-06 \quad 5.5 \%$ $\begin{array}{ll}1.499 \mathrm{E}-05 & 11.2 \%\end{array}$ $1.499 \mathrm{E}-05 \quad 11.2 \%$ $1.618 \mathrm{E}-05 \quad 12.1 \%$ $\begin{array}{ll}1.049 \mathrm{E}-05 & 7.9 \% \\ 1.543 \mathrm{E}-05 & 11.6 \%\end{array}$ $1.543 \mathrm{E}-05 \quad 11.6 \%$ 1.812E-05 $13.6 \%$ 9.305E-06 $7.0 \%$ $2.429 \mathrm{E}-05 \quad 18.2 \%$ $1.813 \mathrm{E}-05 \quad 13.6 \%$ $3.772 \mathrm{E}-05 \quad 28.2 \%$ $2.591 \mathrm{E}-05 \quad 19.4 \%$ $6.625 \mathrm{E}-06 \quad 5.0 \%$ 1.259E-05 $9.4 \%$ $2.806 \mathrm{E}-05 \quad 21.0 \%$ $9.036 \mathrm{E}-06 \quad 6.8 \%$ $1.992 \mathrm{E}-05 \quad 14.9 \%$ $1.679 \mathrm{E}-05 \quad 12.6 \%$ 358E-05 $10.2 \%$ $1.169 \mathrm{E}-05 \quad 8.7 \%$ $\begin{array}{ll}1.169 \mathrm{E}-05 & 8.7 \% \\ . & \end{array}$ 1..772E-05 $15.7 \%$ $1.772 \mathrm{E}-05 \quad 13.3 \%$ $1.569 \mathrm{E}-05 \quad 11.7 \%$ $\begin{array}{ll}1.428 \mathrm{E}-05 & 10.7 \% \\ 1.578 \mathrm{E}-05 & 11.8 \%\end{array}$ .914E-05 $14.3 \%$ $1.126 \mathrm{E}-05 \quad 8.4 \%$ $1.371 \mathrm{E}-05 \quad 10.3 \%$ $1.855 \mathrm{E}-05 \quad 13.9 \%$ $1.764 \mathrm{E}-05 \quad 13.2 \%$ $3.296 \mathrm{E}-05 \quad 24.7 \%$ $6.625 \mathrm{E}-06 \quad 5.0 \%$ $8.119 \mathrm{E}-06 \quad 6.1 \%$ $9.921 \mathrm{E}-06 \quad 7.4 \%$ 1.158E-05 $8.7 \%$ 8.500E-06 $6.4 \%$

$1.789 \mathrm{E}-05 \quad 13.4 \%$

$\begin{array}{ll}1.789 \mathrm{E}-05 & 13.4 \% \\ & 14.9 \%\end{array}$ 
NATIONAL SPENT NUCLEAR FUEL PROGRAM ENGINEERING DESIGN FILE

EDF-NSNF-068

Revision 0

Page 81 of 84

Title: Criticality Analysis for Proposed Maximum Fuel Loading in a Standardized SNF Canister with Type
1a Baskets

\begin{tabular}{|c|c|c|c|c|c|c|c|}
\hline =RR TUBES (GERMANY) [675] & 112.500 & $10.4 \%$ & 1.8000 & $20.9 \%$ & 43.82 & 256.50 & Type $1 a-3$ \\
\hline RR TUBES (DENMARK) [676] & 58.310 & $5.4 \%$ & 0.9330 & $10.8 \%$ & 43.82 & 256.50 & Type 1a-3 \\
\hline FRR TUBES (DENMARK) [678] & 73.500 & $6.8 \%$ & 1.1760 & $13.6 \%$ & 43.82 & 256.50 & Type 1a-3 \\
\hline HIFAR (AUSTRALIA) [680] & 94.809 & $8.7 \%$ & 1.4856 & $17.2 \%$ & 43.82 & 256.50 & Type 1a-3 \\
\hline FRR TUBES (GERMANY) [683] & 90.000 & $8.3 \%$ & 1.4400 & $16.7 \%$ & 43.82 & 256.50 & Type 1a-3 \\
\hline FRR TUBES (AUSTRALIA) [684] & 79.900 & $7.4 \%$ & 1.2784 & $14.8 \%$ & 43.82 & 256.50 & Type 1a-3 \\
\hline FRR TUBES (GERMANY) [685] & 102.000 & $9.4 \%$ & 1.6320 & $18.9 \%$ & 43.82 & 256.50 & Type 1a-3 \\
\hline RECH-1 (CHILE) [708] & 84.081 & $7.7 \%$ & 0.8467 & $9.8 \%$ & 43.82 & 256.50 & Type 1a-2 \\
\hline ASTRA (AUSTRIA) [712] & 195.312 & $18.0 \%$ & 2.8450 & $33.0 \%$ & 43.82 & 256.50 & Type 1a-3 \\
\hline HOR (NETHERLANDS) [713] & 94.194 & $8.7 \%$ & 1.0704 & $12.4 \%$ & 43.82 & 256.50 & Type $1 \mathrm{a}-2$ \\
\hline DR-3 (DENMARK) [714] & 69.564 & $6.4 \%$ & 1.1130 & $12.9 \%$ & 43.82 & 256.50 & Type 1a-3 \\
\hline FRR MTR-S (CANADA) [720] & 121.520 & $11.2 \%$ & 1.2792 & $14.8 \%$ & 43.82 & 256.50 & Type 1a-2 \\
\hline FRR ASTRA (AUSTRIA) [738] & 313.000 & $28.8 \%$ & 3.2947 & $38.2 \%$ & 43.82 & 256.50 & Type 1a-2 \\
\hline FRG-1 (GERMANY) [741] & 184.905 & $17.0 \%$ & 1.9464 & $22.6 \%$ & 43.82 & 256.50 & Type 1a-2 \\
\hline FRG-1 (GERMANY) [742] & 96.281 & $8.9 \%$ & 1.0135 & $11.7 \%$ & 43.82 & 256.50 & Type 1a-2 \\
\hline JEN-1 (SPAIN) [749] & 123.789 & $11.4 \%$ & 1.2018 & $13.9 \%$ & 43.82 & 256.50 & Type 1a-2 \\
\hline NEREIDE (FRANCE) [751] & 152.483 & $14.1 \%$ & 1.7467 & $20.2 \%$ & 43.82 & 256.50 & Type 1a-2 \\
\hline BER-II [HMI] (GERMANY) [758] & 82.971 & $7.6 \%$ & 0.9219 & $10.7 \%$ & 43.82 & 256.50 & Type 1a-2 \\
\hline DR-3 (DENMARK) [759] & 86.969 & $8.0 \%$ & 1.3915 & $16.1 \%$ & 43.82 & 256.50 & Type 1a-3 \\
\hline ENEA SALUGGIA (ITALY) [760] & 130.836 & $12.1 \%$ & 1.9975 & $23.1 \%$ & 43.82 & 256.50 & Type 1a-3 \\
\hline ESSOR (ITALY) [762] & 390.048 & $35.9 \%$ & 2.3639 & $27.4 \%$ & 43.82 & 256.50 & Type 1a-1 \\
\hline IOWA ST. UNIV. [792] & 147.000 & $13.5 \%$ & 2.2511 & $26.1 \%$ & 43.82 & 256.50 & Type 1a-3 \\
\hline JEN-1 (SPAIN) [795] & 124.038 & $11.4 \%$ & 1.2042 & $14.0 \%$ & 43.82 & 256.50 & Type 1a-2 \\
\hline R-2 SVTR (SWEDEN) [801] & 95.367 & $8.8 \%$ & 1.4560 & $16.9 \%$ & 43.82 & 256.50 & Type 1a-3 \\
\hline AN-R1 (COLUMBIA) [803] & 127.362 & $11.7 \%$ & 1.3407 & $15.5 \%$ & 43.82 & 256.50 & Type 1a-2 \\
\hline FRM (GERMANY) [805] & 139.404 & $12.8 \%$ & 1.5968 & $18.5 \%$ & 43.82 & 256.50 & Type 1a-2 \\
\hline FRM (GERMANY) [806] & 72.762 & $6.7 \%$ & 0.7970 & $9.2 \%$ & 43.82 & 256.50 & Type $1 \mathrm{a}-2$ \\
\hline RV-1 (VENEZUELA) [816] & 114.343 & $10.5 \%$ & 1.1397 & $13.2 \%$ & 43.82 & 256.50 & Type 1a-2 \\
\hline $\operatorname{ATR}[843]$ & 621.313 & $57.3 \%$ & 4.9416 & $57.3 \%$ & 43.82 & 256.50 & Type 1a-1 \\
\hline ORR [850] & 139.209 & $12.8 \%$ & 2.1650 & $25.1 \%$ & 43.82 & 256.50 & Type 1a-3 \\
\hline UMRR (ROLLA) [881] & 153.610 & $14.2 \%$ & 1.7656 & $20.5 \%$ & 43.82 & 256.50 & Type 1a-2 \\
\hline JRR-2 (JAPAN) [885] & 156.999 & $14.5 \%$ & 2.3644 & $27.4 \%$ & 43.82 & 256.50 & Type 1a-3 \\
\hline JMTR (JAPAN) [886] & 216.942 & $20.0 \%$ & 2.7118 & $31.4 \%$ & 43.82 & 256.50 & Type 1a-2 \\
\hline FRJ (GERMANY) [933] & 37.564 & $3.5 \%$ & 0.5963 & $6.9 \%$ & 43.82 & 256.50 & Type 1a-3 \\
\hline R-2 SVTR (SWEDEN) [942] & 139.438 & $12.9 \%$ & 2.1452 & $24.9 \%$ & 43.82 & 256.50 & Type 1a-3 \\
\hline RPI (PORTUGAL) [943] & 122.664 & $11.3 \%$ & 1.4049 & $16.3 \%$ & 43.82 & 256.50 & Type 1a-2 \\
\hline ORR [944] & 238.255 & $22.0 \%$ & 2.4461 & $28.3 \%$ & 43.82 & 256.50 & Type 1a-2 \\
\hline SAPHIR (SWITZERLAND) [945] & 121.738 & $11.2 \%$ & 1.3913 & $16.1 \%$ & 43.82 & 256.50 & Type 1a-2 \\
\hline UNIV OF VIRGINIA [952] & 220.367 & $20.3 \%$ & 2.5240 & $29.2 \%$ & 43.82 & 256.50 & Type 1a-2 \\
\hline IOWA ST. UNIV. [953] & 158.093 & $14.6 \%$ & 2.3709 & $27.5 \%$ & 43.82 & 256.50 & Type 1a-3 \\
\hline IEA-R1 (BRAZIL) [954] & 102.425 & $9.4 \%$ & 1.2266 & $14.2 \%$ & 43.82 & 256.50 & Type 1a-2 \\
\hline MURR (COLUMBIA) [962] & 593.895 & $54.7 \%$ & 7.1944 & $83.4 \%$ & 43.82 & 256.50 & Type $1 \mathrm{a}-2$ \\
\hline RJ TUBES (GERMANY) [999] & 116.307 & $10.7 \%$ & 1.8461 & $21.4 \%$ & 43.82 & 256.50 & Type 1a-3 \\
\hline RJ (GERMANY) [1000] & 106.681 & $9.8 \%$ & 1.6934 & $19.6 \%$ & 43.82 & 256.50 & Type 1a-3 \\
\hline
\end{tabular}

$13.157916 .7 \%$

$6.8199 \quad 8.7 \%$

$8.5965 \quad 10.9 \%$

$11.0888 \quad 14.1 \%$

$10.526313 .4 \%$

$9.345011 .9 \%$

$11.9298 \quad 15.2 \%$

$6.5560 \quad 8.3 \%$

$22.8435 \quad 29.1 \%$

$7.3446 \quad 9.3 \%$

$8.136110 .3 \%$

$9.475212 .1 \%$

$24.405531 .0 \%$

$14.4175 \quad 18.3 \%$

$7.5073 \quad 9.5 \%$

$9.6522 \quad 12.3 \%$

$11.8895 \quad 15.1 \%$

$6.4695 \quad 8.2 \%$

$10.1718 \quad 12.9 \%$

$15.3024 \quad 19.5 \%$

$15.2066 \quad 19.3 \%$

$17.1930 \quad 21.9 \%$

$9.671512 .3 \%$

$11.1541 \quad 14.2 \%$

$\begin{array}{rr}9.9308 & 12.6 \% \\ 10.8697 & 13.8 \%\end{array}$

$5.6735 \quad 7.2 \%$

$8.9156 \quad 11.3 \%$

$24.2227 \quad 30.8 \%$

$16.2818 \quad 20.7 \%$

$11.9773 \quad 15.2 \%$

$18.3624 \quad 23.4 \%$

$16.9156 \quad 21.5 \%$

$4.3935 \quad 5.6 \%$

$16.3085 \quad 20.7 \%$

$9.5645 \quad 12.2 \%$

$18.5773 \quad 23.6 \%$

$9.492212 .1 \%$

$17.1826 \quad 21.9 \%$

$18.4904 \quad 23.5 \%$

$7.9864 \quad 10.2 \%$

$46.3076 \quad 58.9 \%$

$\begin{array}{ll}46.3076 & 58.9 \% \\ 13.6031 & 17.3 \%\end{array}$

$\begin{array}{ll}13.6031 & 17.3 \% \\ 12.4773 & 15.9 \%\end{array}$
5.543E-05 $13.9 \%$

$2.869 \mathrm{E}-05 \quad 7.2 \%$

$3.616 \mathrm{E}-05 \quad 9.1 \%$

4.695E-05 $11.8 \%$

4.434E-05 $\quad 11.1 \%$

$3.931 \mathrm{E}-05 \quad 9.9 \%$

$2851 \mathrm{E}-04 \quad 71.5 \%$

$1.190 \mathrm{E}-04 \quad 71.5 \%$

1.190E-04 $29.8 \%$

$\begin{array}{ll}4.732 \mathrm{E}-05 & 11.9 \% \\ 4.167 \mathrm{E}-05 & 10.4 \%\end{array}$

4.167E-05 $10.4 \%$

$5.644 \mathrm{E}-05 \quad 14.2 \%$

$1.454 \mathrm{E}-04 \quad 36.4 \%$

$9.531 \mathrm{E}-05 \quad 23.9 \%$

$5.153 \mathrm{E}-05 \quad 12.9 \%$

$7.413 \mathrm{E}-05 \quad 18.6 \%$

3.837E- $05 \quad 9.6 \%$

$5.209 \mathrm{E}-05 \quad 13.1 \%$

8.364E-05 21.0\%

1.093E-04 $27.4 \%$

$1.087 \mathrm{E}-04 \quad 27.2 \%$

$5.164 \mathrm{E}-05 \quad 12.9 \%$

$6.113 E-04 \quad 153.3 \%$

1.958E-04 $49.1 \%$

6.679E-05 $16.7 \%$

$3.333 \mathrm{E}-05 \quad 8.4 \%$

$\begin{array}{ll}3.333 E-05 & 8.4 \% \\ 4.887 \mathrm{E}-05 & 12.3 \%\end{array}$

$1.838 \mathrm{E}-04 \quad 46.1 \%$

$9.043 \mathrm{E}-05 \quad 22.7 \%$

$6.837 \mathrm{E}-05 \quad 17.1 \%$

$7.271 \mathrm{E}-05 \quad 18.2 \%$

1.171E-04 29.3\%

$2.239 \mathrm{E}-05 \quad 5.6 \%$

$9.008 \mathrm{E}-04 \quad 225.8 \%$

$5.790 \mathrm{E}-05 \quad 14.5 \%$

$9.817 \mathrm{E}-05 \quad 24.6 \%$

$5.808 \mathrm{E}-05 \quad 14.6 \%$

$1.066 \mathrm{E}-04 \quad 26.7 \%$

$7.816 \mathrm{E}-05 \quad 19.6 \%$

$4.982 \mathrm{E}-05 \quad 12.5 \%$

2.601E-04 $\quad 65.2 \%$

$6.933 \mathrm{E}-05 \quad 17.4 \%$
2.236E-05 16.7\% $1.159 \mathrm{E}-05 \quad 8.7 \%$ $1.461 \mathrm{E}-05 \quad 10.9 \%$ $1.884 \mathrm{E}-05 \quad 14.1 \%$ $1.789 \mathrm{E}-05 \quad 13.4 \%$ $1.588 \mathrm{E}-05 \quad 11.9 \%$ 2.027E-05 $15.2 \%$ $1.114 \mathrm{E}-05 \quad 8.3 \%$ $3.882 \mathrm{E}-05 \quad 29.1 \%$

$1.248 \mathrm{E}-05 \quad 9.3 \%$

$1.248 \mathrm{E}-05$ - $9.3 \%$

$1.383 \mathrm{E}-05 \quad 10.3 \%$

$1.610 \mathrm{E}-05 \quad 12.1 \%$ 4.147E-05 $31.0 \%$ $2.450 \mathrm{E}-05 \quad 18.3 \%$ $1.276 \mathrm{E}-05 \quad 9.5 \%$

$1.640 \mathrm{E}-05 \quad 12.3 \%$

.020E-05 $15.1 \%$

$1.099 \mathrm{E}-05 \quad 8.2 \%$

$1.728 \mathrm{E}-05 \quad 12.9 \%$

$2.600 \mathrm{E}-05 \quad 19.5 \%$

$2.584 \mathrm{E}-05 \quad 19.3 \%$

$2.922 \mathrm{E}-05 \quad 21.9 \%$

$1.643 \mathrm{E}-05 \quad 12.3 \%$

$1.687 \mathrm{E}-05 \quad 12.6 \%$

$\begin{array}{ll}1.687 \mathrm{E}-05 & 12.6 \% \\ 1.847 \mathrm{E}-05 & 13.8 \%\end{array}$

$\begin{array}{ll}1.847 \mathrm{E}-05 & 13.8 \% \\ 9.641 \mathrm{E}-06 & 7.2 \%\end{array}$

$\begin{array}{cc}9.641 \mathrm{E}-06 & 7.2 \% \\ 1.515 \mathrm{E}-05 & 11.3 \%\end{array}$

$1.515 E-05 \quad 11.3 \%$

4.116E-05 $30.8 \%$

$\begin{array}{ll}2.767 E-05 & 20.7 \% \\ 2.035 E-05 & 15.2 \%\end{array}$

$3.120 \mathrm{E}-05 \quad 23.4 \%$

$2.874 \mathrm{E}-05 \quad 21.5 \%$

$7.466 \mathrm{E}-06 \quad 5.6 \%$

$2.771 \mathrm{E}-05 \quad 20.7 \%$

$1.625 \mathrm{E}-05 \quad 12.2 \%$

$3.157 \mathrm{E}-05 \quad 23.6 \%$

$1.613 \mathrm{E}-05 \quad 12.1 \%$

$2.920 \mathrm{E}-05 \quad 21.9 \%$

$3.142 \mathrm{E}-05 \quad 23.5 \%$

$1.357 \mathrm{E}-05 \quad 10.2 \%$

7.869E-05 $\quad 58.9 \%$

$2.312 \mathrm{E}-05 \quad 17.3 \%$ 
NATIONAL SPENT NUCLEAR FUEL PROGRAM ENGINEERING DESIGN FILE

EDF-NSNF-068

Revision 0

Page 82 of 84

Title: Criticality Analysis for Proposed Maximum Fuel Loading in a Standardized SNF Canister with Type
1a Baskets UNIV OF MICHIGAN (CONTROL) [1005]

$61.6815 .7 \%$ $\begin{array}{lll}012.061 & 19.5 \%\end{array}$ \begin{tabular}{l|rr}
\hline DR-3 (DENMARK) [1059] & 82.187 & $7.6 \%$ \\
\hline
\end{tabular} \begin{tabular}{l|rr} 
MNR (CANADA) [1064] & 100.211 & $9.2 \%$ \\
\hline
\end{tabular} \begin{tabular}{l|lll} 
FRR FMRB (GERMANY) [1066] & 111.339 & $10.3 \%$
\end{tabular} \begin{tabular}{l|r|r|}
\hline FRR MTR-S (GERMANY) [1067] & 168.000 & $15.5 \%$
\end{tabular} \begin{tabular}{l|r|r} 
FRR MTR-S (GERMANY) [1068] & 74.536 & $6.9 \%$ \\
\hline
\end{tabular} \begin{tabular}{l|r|r}
\hline GRR (GREECE) [1069] & 114.823 & $10.6 \%$ \\
\hline
\end{tabular} \begin{tabular}{l|r|r}
\hline JRR-4 (JAPAN) [1070] & 131.348 & $12.1 \%$ \\
\hline
\end{tabular} \begin{tabular}{l|r|r|}
\hline JRR-4 (JAPAN) [1071] & 150.086 & $13.8 \%$
\end{tabular} \begin{tabular}{l|ll}
\hline RU-1 (URAGUAY) [1073] & 104.480 & $9.6 \%$
\end{tabular} \begin{tabular}{l|r|r|}
\hline IEA-R1 (BRAZIL) [1076] & 131.078 & $12.1 \%$
\end{tabular}

$\begin{array}{llllll}0.6412 & 7.4 \% & 43.82 & 256.50 & \text { Type } 1 \mathrm{a}-2 & 2\end{array}$

$\begin{array}{ll}0.6412 & 7.4 \% \\ 1.3150 & 30.7 \%\end{array}$

$1.3150 \quad 15.2 \%$

$1.4802 \quad 17.2 \%$

$1.1720 \quad 13.6 \%$

$1.9091 \quad 22.1 \%$

$0.7846 \quad 9.1 \%$

$1.4759 \quad 17.1 \%$

$1.9781 \quad 22.9 \%$

$\begin{array}{ll}2.2603 & 26.2 \% \\ 1.2796 & 14.8 \%\end{array}$

$1.27961517 .8 \%$

$\begin{array}{lll}43.82 & 256.50 & \text { Type } 1 \mathrm{a}-2 \\ 43.82 & 256.50 & \text { Type } 1 \mathrm{a}-3\end{array}$

$43.82 \quad 256.50$ Type $1 \mathrm{a}-3$

$43.82 \quad 256.50$ Type $1 \mathrm{a}-2$

$43.82 \quad 256.50$ Type 1a-2

$43.82 \quad 256.50$ Type $1 \mathrm{a}-2$

$43.82 \quad 256.50$ Type $1 \mathrm{a}-3$

$43.82 \quad 256.50$ Type $1 \mathrm{a}-3$

$43.82 \quad 256.50$ Type $1 \mathrm{a}-3$

$43.82 \quad 256.50$ Type $1 \mathrm{a}-2$

$43.82 \quad 256.50$ Type $1 \mathrm{a}-2$

U metal

\begin{tabular}{|l|l}
\hline EBWR ENRICHED HEAVY [64] & 713.737 \\
\hline
\end{tabular} \begin{tabular}{l|r|r|}
\hline HWCTR RMT \& SMT [790] & 32.603 & $3.0 \%$ \\
\hline HWCTR TWNT [791] & 143.923 & $13.3 \%$ \\
\hline
\end{tabular} \begin{tabular}{|l|r|r}
\hline HWCTR TWNT [791] & 143.923 & $13.3 \%$ \\
\hline HWCTR ETWO [867] & 124.791 & $11.5 \%$
\end{tabular} \begin{tabular}{|l|r|r}
\hline HWCTR ETWO [867] & 124.791 & $11.5 \%$ \\
\hline EBWR ENRICHED THIN [887] & 531.147 & $49.0 \%$ \\
\hline
\end{tabular} EBWR NORMAL HEAVY [889] $361.153 \quad 33.3 \%$

EBWR NORMAL THIN [890]

$286.30926 .4 \%$

\section{UZr/UMo}

CP-5 CONVERTER CYLINDERS [36] $559.695 \quad 51.6 \%$ $\begin{array}{llll}\text { HWCTR DRIVER [117] } & 403.568 & 37.2 \%\end{array}$

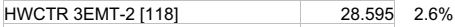
\begin{tabular}{l|r|r}
\hline SPEC (ORME) [208] & 123.000 & $11.3 \%$
\end{tabular}

$\mathrm{UZrHx}$

\begin{tabular}{|l|r|r}
\hline \multicolumn{1}{|c|}{ GA RERTR [90] } & 381.44 & $35.2 \%$ \\
\hline BER-II TRIGA (GERMANY) [236] & 192.50 & $17.7 \%$ \\
\cline { 1 - 2 } & & \\
\cline { 1 - 2 } HFBR [102] & 211.187 & $19.5 \%$ \\
\hline ORR [461] & 152.765 & $14.1 \%$ \\
\hline HFBR [706] & 216.786 & $20.0 \%$ \\
\hline ORR [753] & 44.725 & $4.1 \%$ \\
\hline ORR [903] & 176.838 & $16.3 \%$ \\
\hline GCRE (1Z SERIES) [916] & 315.764 & $29.1 \%$ \\
\hline
\end{tabular}

$\begin{array}{lllllll}4.8448 & 56.1 \% & 43.82 & 256.50 & \text { Type 1a-1 } & 1 & 1 \\ 0.1088 & 1.3 \% & 43.82 & 414.02 & \text { Type 1a-1 } & 1 & 1 \\ 0.4885 & 5.7 \% & 43.82 & 414.02 & \text { Type 1a-1 } & 1 & 1 \\ 0.4164 & 4.8 \% & 43.82 & 414.02 & \text { Type 1a-1 } & 1 & 1 \\ & & & & & & \\ 3.6054 & 41.8 \% & 43.82 & 256.50 & \text { Type 1a-1 } & 1 & 1 \\ & & & & & & \\ 2.4515 & 28.4 \% & 43.82 & 256.50 & \text { Type 1a-1 } & 1 & 1 \\ & & & & & & \\ 1.9434 & 22.5 \% & 43.82 & 256.50 & \text { Type 1a-1 } & 1 & 1 \\ & & & & & & \\ 9.181 & 106.4 \% & 43.82 & 256.5 & \text { Type 1a-3 } & 3 & 3 \\ 1.358 & 15.7 \% & 43.82 & 414.02 & \text { Type 1a-1 } & 1 & 1 \\ 0.248 & 2.9 \% & 43.82 & 414.02 & \text { Type 1a-2 } & 2 & 2 \\ 3.725 & 43.2 \% & 43.82 & 256.5 & \text { Type 1a-4 } & 4 & 4 \\ & & & & & & \\ & & & & & & \\ 4.031 & 46.7 \% & 43.82 & 256.5 & \text { Type 1a-2 } & 2 & 2 \\ 2.059 & 23.9 \% & 43.82 & 256.5 & \text { Type 1a-2 } & 2 & 2 \\ & & & & & & \\ 3.394 & 39.3 \% & 43.82 & 256.5 & \text { Type 1a-3 } & 3 & 3 \\ 2.217 & 25.7 \% & 43.82 & 256.5 & \text { Type 1a-3 } & 3 & 30 \\ 3.480 & 40.3 \% & 43.82 & 256.5 & \text { Type 1a-3 } & 3 & 3 \\ 0.696 & 8.1 \% & 43.82 & 256.5 & \text { Type 1a-3 } & 3 & 3 \\ 2.750 & 31.9 \% & 43.82 & 256.5 & \text { Type 1a-3 } & 3 & 3 \\ 3.965 & 46.0 \% & 43.82 & 256.5 & \text { Type 1a-3 } & 3 & 3\end{array}$

$1.234 \quad 3.8 \%$

$\begin{array}{ll}4.241 \quad 13.0 \% \\ 2.406 & 7.0 \%\end{array}$

$2.466 \quad 7.6 \%$

$3.006 \quad 9.2 \%$

$2.227 \quad 6.8 \%$

$3.360 \quad 10.3 \%$

$1.491 \quad 4.6 \%$

$3.445 \quad 10.6 \%$

$3.940 \quad 12.1 \%$

$4.503 \quad 13.8 \%$

$2.090 \quad 6.4 \%$

$2.622 \quad 8.1 \%$

$7.137 \quad 21.9 \%$

$0.326 \quad 1.0 \%$

$1.439 \quad 4.4 \%$

$1.248 \quad 3.8 \%$

$5.311 \quad 16.3 \%$

$3.612 \quad 11.1 \%$

$2.863 \quad 8.8 \%$

$16.791 \quad 51.6 \%$

$\begin{array}{ll}4.036 & 12.4 \% \\ 0.572 & 1.8 \%\end{array}$

$4.920 \quad 15.1 \%$

\begin{tabular}{ll}
$7.63 \quad 23.4 \%$ \\
\hline .85 & $11.8 \%$
\end{tabular} $3.8511 .8 \%$

$29.7373 \quad 37.8 \%$

$6.336 \quad 19.5 \%$ $4.583 \quad 14.1 \%$ $\begin{array}{ll}6.504 & 20.0 \% \\ 1.342 & 4.1 \%\end{array}$ $1.342 \quad 4.1 \%$ $5.305 \quad 16.3 \%$ $9.473 \quad 29.1 \%$ $15.0072 \quad 19.1 \%$

$4.8094 \quad 6.1 \%$

$16.5350 \quad 21.0 \%$

$9.6125 \quad 12.2 \%$

$8.6814 \quad 11.0 \%$

$\begin{array}{rr}8.6814 & 11.0 \% \\ 13.0994 & 16.7 \%\end{array}$

$5.8118 \quad 7.4 \%$

$13.4296 \quad 17.1 \%$

$15.3624 \quad 19.5 \%$

$17.5539 \quad 22.3 \%$

$8.146610 .4 \%$

$10.2205 \quad 13.0 \%$

$27.8260 \quad 35.4 \%$

$0.7875 \quad 1.0 \%$

$3.47624 .4 \%$

$20.7075 \quad 26.3 \%$

$14.0800 \quad 17.9 \%$

$11.1621 \quad 14.2 \%$

$65.461 \quad 83.3 \%$

$9.748 \quad 12.4 \%$

$1.381 \quad 1.8 \%$

$19.181 \quad 24.4 \%$

$24.700 \quad 31 \%$

$17.867 \quad 23 \%$

$25.355 \quad 32 \%$

$5.231 \quad 7 \%$

$20.683 \quad 26.3 \%$

$36.931 \quad 47.0 \%$
2.662E-05 $6.7 \%$

$1.170 \mathrm{E}-04 \quad 29.3 \%$

$4.923 \mathrm{E}-05 \quad 12.3 \%$

6.9255-05 $\quad 15 \%$

$\begin{array}{ll}6.055 \mathrm{E}-05 & 15.2 \% \\ 2.173 \mathrm{E}-04 & 54.5 \%\end{array}$

$2.173 \mathrm{E}-04 \quad 54.5 \%$

8.440E-05 $21.2 \%$

$3.462 \mathrm{E}-05 \quad 8.7 \%$

9.872E-05 $24.8 \%$

$6.599 \mathrm{E}-05 \quad 16.5 \%$

$7.540 \mathrm{E}-05 \quad 18.9 \%$

$5.828 \mathrm{E}-05 \quad 14.6 \%$

$6.099 \mathrm{E}-05 \quad 15.3 \%$

1.37E- $04 \quad 34.3 \%$

$1.28 \mathrm{E}-05 \quad 3.2 \%$

$1.48 \mathrm{E}-05 \quad 3.7 \%$

4.97E-05 $12.4 \%$

1.02E-04 25.5\%

$6.92 \mathrm{E}-05 \quad 17.3 \%$

$5.48 \mathrm{E}-05 \quad 13.7 \%$

1.992E-03 499.3\%

1.299E-04 $32.6 \%$

$2.959 \mathrm{E}-06 \quad 0.7 \%$

3.26E-04 $81.7 \%$

$\begin{array}{ll}3.68 \mathrm{E}-05 & 21.8 \%\end{array}$

1.457E-04 36.5\%

$9.260 \mathrm{E}-05 \quad 23.2 \%$

$1.767 \mathrm{E}-04 \quad 44.3 \%$

$2.883 \mathrm{E}-05 \quad 7.2 \%$

1.151E-04 $28.9 \%$

$4.143 \mathrm{E}-04 \quad 103.9 \%$
8.172E-06 $6.1 \%$

2.810E-05 21.0\%

1.633E-05 $12.2 \%$

$1.992 \mathrm{E}-05 \quad 14.9 \%$

.475E-05 $11.0 \%$

$2.226 \mathrm{E}-05 \quad 16.7 \%$

$\begin{array}{ll}2.876 E-06 & 7.4 \%\end{array}$

$2.282 \mathrm{E}-05 \quad 17.1 \%$

$\begin{array}{ll}2.610 \mathrm{E}-05 & 19.5 \% \\ 2.983 \mathrm{E}-05 & 22.3 \%\end{array}$

$1.384 \mathrm{E}-05 \quad 10.4 \%$

$137 \mathrm{E}-05 \quad 13.0 \%$

4.73E-05 $35.4 \%$

$1.34 \mathrm{E}-06 \quad 1.0 \%$

$5.91 \mathrm{E}-06 \quad 4.4 \%$

$5.12 \mathrm{E}-06 \quad 3.8 \%$

3.52E-05 $26.3 \%$

$2.39 \mathrm{E}-05 \quad 17.9 \%$

1.90E-05 $14.2 \%$

$1.112 \mathrm{E}-04 \quad 83.3 \%$ $1.656 \mathrm{E}-05 \quad 12.4 \%$ $2.347 \mathrm{E}-06 \quad 1.8 \%$

$3.259 \mathrm{E}-05 \quad 24.4 \%$

1.31E-04 $97.8 \%$ $6.59 \mathrm{E}-05 \quad 49.4 \%$

4.197E-05 31.4\% $3.036 \mathrm{E}-05 \quad 22.7 \%$ 4.309E-05 $32.3 \%$ 8.889E-06 $\quad 6.7 \%$

$3.515 \mathrm{E}-05 \quad 26.3 \%$

6.276E-05 $47.0 \%$ 
NATIONAL SPENT NUCLEAR FUEL PROGRAM ENGINEERING DESIGN FILE

$$
\text { EDF-NSNF-068 }
$$

Title: Criticality Analysis for Proposed Maximum Fuel Loading in a Standardized SNF Canister with Type
1a Baskets

HFBR [961]

$211.19 \quad 19.5 \%$

$\begin{array}{ll}3.394 & 39.3 \% \\ 2.098 & 24.3 \%\end{array}$

$\begin{array}{llll}43.82 & 256.5 & \text { Type } 1 \mathrm{a}-3 \quad 3 \\ 43.82 & 256.5 & \text { Typ } 1 \mathrm{a}-3 & 3\end{array}$

30
30

$6.336 \quad 19.5 \%$

$24.700 \quad 31.4 \%$

1.457E-04 $36.5 \%$

4.197E-05 $31.4 \%$

U/Th oxide

$1059.7197 .7 \%$

$6.570 \quad 76.1 \%$

$\begin{array}{lllll}43.82 & 256.5 & \text { Type } 1 \mathrm{a}-1 & 1 & 10\end{array}$

Th-U carbide

PEACH BOTTOM UNIT I CORE I

[169]

[170]

$23.3 \%$

PEACH BOTTOM UNIT I CORE

[171]

$253.00 \quad 23.3 \%$

$218.05 \quad 20.1 \%$

$117.14 \quad 10.8 \%$

PEACH BOTTOM UNIT I CORE II

$103.399 .5 \%$

LEU oxide

HWCTR SPRO [115]

$17.67 \quad 1.6 \%$

\begin{tabular}{l|l}
17.67 & $1.6 \%$ \\
20.91 & $1.9 \%$
\end{tabular}

$\begin{array}{lllllll}0.6917 & 8.0 \% & 43.815 & 414.02 & \text { Type } 1 \mathrm{a}-1 & 1 & 10\end{array}$

$\begin{array}{lllllll}0.5962 & 6.9 \% & 43.815 & 414.02 & \text { Type } 1 \mathrm{a}-1 & 1 & 10\end{array}$

$\begin{array}{lllllll}0.3660 & 4.2 \% & 43.815 & 414.02 & \text { Type } 1 \mathrm{a}-1 & 1 & 10\end{array}$

$0.3230 \quad 3.7 \%$

$43.815 \quad 414.02$ Type 1a-1 $1 \quad 10$

$0.3710 \quad 4.3 \%$

$\begin{array}{llll}43.815 & 256.5 & \text { Type } 1 \mathrm{a}-4 \quad 4\end{array}$

$0.6097 \quad 7.1 \%$

$10.597 \quad 32.6 \%$

$41.314152 .5 \%$

$2.530 \quad 7.8 \%$

$2.180 \quad 6.7 \%$

$1.1713 .6 \%$

$1.034 \quad 3.2 \%$

$0.706868 \quad 2.2 \%$

$0.836212 \quad 2.6 \%$ $\begin{array}{ll}6.1108 & 7.8 \% \\ 5.2666 & 6.7 \% \\ 2.8292 & 3.6 \% \\ & \\ 2.4971 & 3.2 \% \\ & \\ & \\ 2.756 & 3.5 \% \\ 3.260 & 4.1 \%\end{array}$
$8.776 \mathrm{E}-05 \quad 22.0 \%$

$1.30 \mathrm{E}-03 \quad 326.7 \%$

$7.02 \mathrm{E}-06 \quad 5.3 \%$

$2.786 \mathrm{E}-05 \quad 7.0 \%$

$2.401 \mathrm{E}-05 \quad 6.0 \%$

$1.511 \mathrm{E}-05 \quad 3.8 \%$

1.333E-05 $3.3 \%$

$4.391 \mathrm{E}-05 \quad 11.0 \%$

$7.216 \mathrm{E}-05 \quad 18.1 \%$
$1.045 \mathrm{E}-05 \quad 7.8 \%$

$9.005 \mathrm{E}-06 \quad 6.7 \%$

4.837E-06 $3.6 \%$

$4.269 \mathrm{E}-06 \quad 3.2 \%$

$2.919 \mathrm{E}-06 \quad 2.2 \%$ $3.453 \mathrm{E}-06 \quad 2.6 \%$ 
NATIONAL SPENT NUCLEAR FUEL PROGRAM ENGINEERING DESIGN FILE

EDF-NSNF-068

Revision 0

Page 84 of 84

Title: Criticality Analysis for Proposed Maximum Fuel Loading in a Standardized SNF Canister with Type 1a Baskets

\section{B-1 References}

DOE 2004b, Packaging Strategies for Criticality Safety for “Other” DOE Fuels in a Repository. DOE/SNF/REP-090, Rev. 0. Idaho Falls, Idaho: U.S. Department of Energy, Idaho Operations Office, ACC: MOL.20040708.0386. 